\title{
AS QUOTAS TARIFÁRIAS E O ACESSO DOS PRODUTOS AGROINDUSTRIAIS BRASILEIROS AO MERCADO INTERNACIONAL
}

\author{
Joaquim Henrique da CunHa FiLho
}

Dissertação apresentada à Escola Superior de Agricultura "Luiz de Queiroz", Universidade de São Paulo, para obtenção do título de Mestre em Ciências, Área de Concentração: Economia Aplicada.

\author{
P I R A C I C A B A \\ Estado de São Paulo - Brasil \\ Dezembro - 2003
}




\title{
AS QUOTAS TARIFÁRIAS E O ACESSO DOS PRODUTOS AGROINDUSTRIAIS BRASILEIROS AO MERCADO INTERNACIONAL
}

\author{
Joaquim Henrique da Cunha Filho
}

Bacharel em Ciências Econômicas

Orientador: Prof. Dr. MARCOS SAWAYA JANK

Dissertação apresentada à Escola Superior de Agricultura "Luiz de Queiroz", Universidade de São Paulo, para obtenção do título de Mestre em Ciências, Área de Concentração: Economia Aplicada.

\author{
P I R A C I C A B A \\ Estado de São Paulo - Brasil \\ Dezembro - 2003
}


Dados Internacionais de Catalogação na Publicação (CIP)
DIVISÃO DE BIBLIOTECA E DOCUMENTAÇÃO - ESALQ/USP

\section{Cunha Filho, Joaquim Henrique}

As quotas tarifárias e o acesso dos produtos agroindustriais brasileiros ao mercado internacional / Joaquim Henrique Cunha Filho. - - Piracicaba, 2003.

159 p. : il.

Dissertação (mestrado) - - Escola Superior de Agricultura Luiz de Queiroz, 2004.

Bibliografia.

1. Exportação 2. Mercado externo 3. Produtos agroindustriais 4. Tarifas I. Título

CDD 382.7

"Permitida a cópia total ou parcial deste documento, desde que citada a fonte - O autor" 


\section{OFEREÇO}

A Na $\mathrm{S}^{\mathrm{a}}$ Auxiliadora, a quem expresso minha total devoção.

\section{DEDICO}

Aos meus pais, com toda minha admiração e respeito. À Lilian que partilhou essa longa jornada ao meu lado. 


\section{AGRADECIMENTOS}

Agradeço ao Pai por me oferecer um "talento", o qual, com afinco, tento fazê-lo multiplicar em todos os instantes de minha vida. Agradeço ao Pai, ainda, a saúde, as oportunidades e os meios para atingir meus objetivos.

Agradeço ao meu orientador, Prof. Marcos Sawaya Jank, exemplo de dedicação e entrega ao trabalho. Agradeço a confiança e a responsabilidade depositadas em mim e espero ter conseguido cumprir, a contento, todas as suas expectativas.

Agradeço a Profa. Heloísa Lee Burnquist e ao Prof. Joaquim Bento de Souza Ferreira Filho pelas importantes sugestões e críticas ao presente trabalho.

Agradeço, em especial, a Profa. Sílvia Helena Galvão de Miranda, a quem expresso minha admiração, não só como profissional e excelente professora, mas como amiga e conselheira para todas as horas.

Agradeço aos funcionários da ESALQ/USP, principalmente à Maielli, ao Álvaro, a Ligiana e a Helena, que sempre acolhem e tratam, nós alunos, com muito carinho e dedicação. Em especial, agradeço a Dona Maria, com quem, longamente, por várias vezes, conversei. A Dona Maria, em muitos momentos, me confortou e reduziu minha ansiedade cotidiana com sua voz mansa e serena. De sua simplicidade, pude extrair grandes ensinamentos sobre humildade e perseverança. Lições, estas, que levo para minha vida. 
Agradeço ao André Nassar, Mário Jales, Gustavo Bracale, Leandro Rocha e Telma Pereira, todos componentes da equipe ICONE, a qual também tenho a honra de pertencer, ao Rogério Freitas e ao pessoal do Grupo de Estudos em Comércio Internacional (GECINT) do LES/ESALQ, pelos palpites, sugestões, eventuais ajudas e incentivos.

Agradeço aos amigos que fiz durante o mestrado, o Julce, o Paulão, o Ronaldo, o Lucilio, o Mauro, o Ricardinho, o Humberto, o Ari, o Gustavo "Talha", o Alexandre "Conchas", o Elisson "Tiziu", e, de forma especial, ao Nicolella e ao Sílvio, com quem dividi minha morada por dois anos, durante o período de aulas no mestrado. Certamente, nossa convivência será transmitida aos meus filhos e netos como sinônimo de amizade e companheirismo.

Agradeço à Anna Paula Cunha, com quem troco importantes impressões, angústias e expectativas. Suas palavras amigas, confortadoras e de incentivo, próprias de uma verdadeira amiga, antes de irmã, foram e são de extrema importância na minha vida.

Agradeço a Zouha e ao Cido, meus sogros, que sempre que me acolheram algumas vezes na sua casa como um verdadeiro filho.

Agradeço a Lilian Maluf de Lima por ter suportado meu mau humor e minhas reclamações sempre que as coisas não davam certo, meu nervosismo e ansiedade durante o período de aulas, e principalmente, no período de conclusão deste trabalho. Agradeço ainda, pelo carinho com que me consolou, pela atenção com que me ouviu e pela paciência com que me agüentou nestes quase três anos de mestrado. Agradeço, acima de tudo, por estar ao meu lado e por demonstrar que me ama.

Por fim, agradeço a Dona Odette e ao Dr. Henrique, meus pais, por me ensinarem os princípios da disciplina e responsabilidade e a trabalhar com rigor e dedicação. 
Agradeço aos meus pais por me ensinarem que o trabalho é a melhor forma de se construir um Homem e por demonstrarem toda a coragem necessária para enfrentar os desafios e percalços da vida, nem sempre fáceis ou passageiros.

Agradeço por me ensinarem os princípios da fé, não só ao Pai, mas também em mim, em meu trabalho e nas minhas potencialidades, o que me faz trabalhar, mesmo que de forma ínfima, por um mundo melhor.

Agradeço aos meus pais por me transmitirem valores de honestidade, lealdade e de confiança, a acreditar mais nas pessoas e a ser sempre prestativo.

Agradeço aos meus pais por respeitarem meus posicionamentos, mesmo que estes sejam diametralmente opostos aos seus. Agradeço por respeitarem minhas escolhas, sempre de forma incontestável e incondicional, arcando, quase sempre, com seu ônus financeiro, como foi o caso deste mestrado. Dizem que é investimento... Agradeço por sempre pedirem minha opinião, mesmo quando eu não deixava de ser um "mulequinho branquelo e magrinho".

Mas acima de tudo, agradeço aos meus pais por demonstrarem a todo instante o Amor que sentem por mim. A eles dedico os três anos de trabalho sintetizados neste trabalho. 


\section{SUMÁRIO}

Página

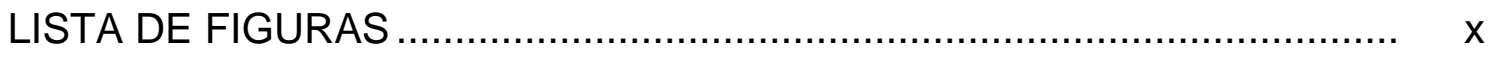

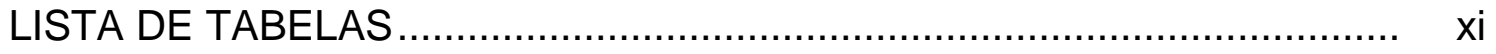

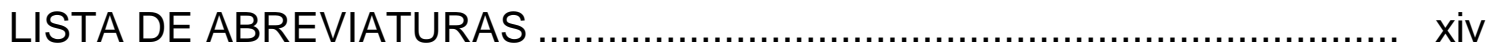

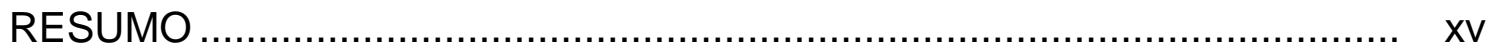

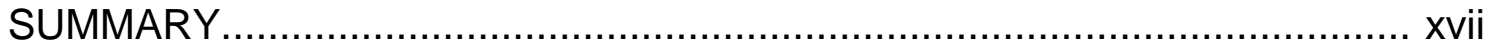

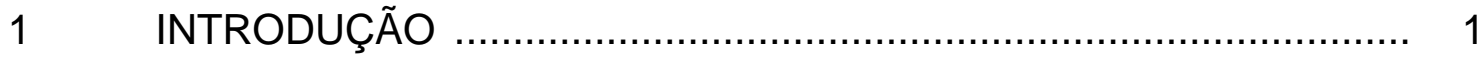

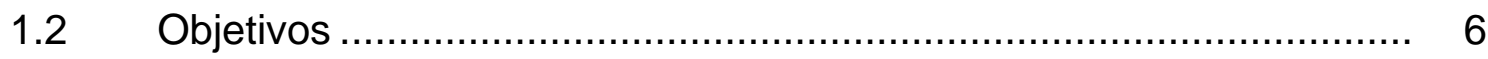

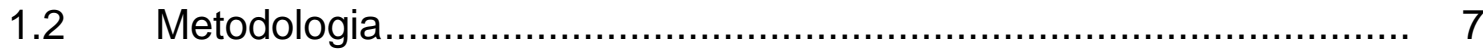

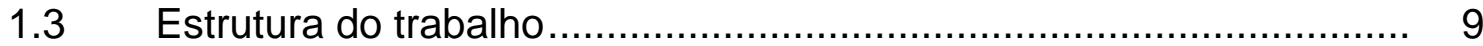

2 O SISTEMA DE QUOTAS TARIFÁRIAS: FUNCIONAMENTO, CARACTERÍSTICA E INCONSISTÊNCIAS ............................. 11

$2.1 \quad$ O sistema de quotas tarifárias............................................. 14

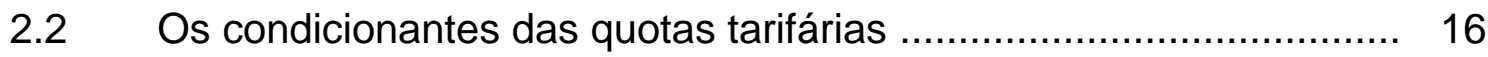

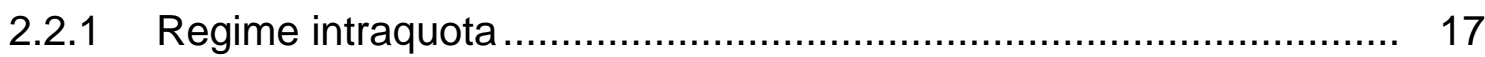

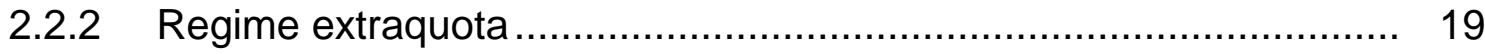

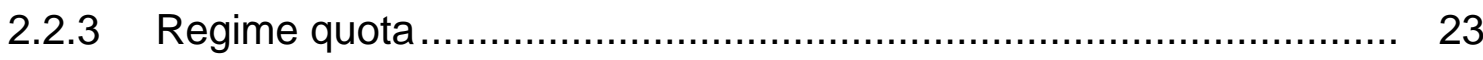

2.2.4 Considerações adicionais sobre os regimes das quotas tarifárias ... 26

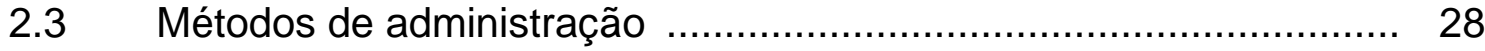

2.3.1 Tarifa aplicada ........................................................... 29

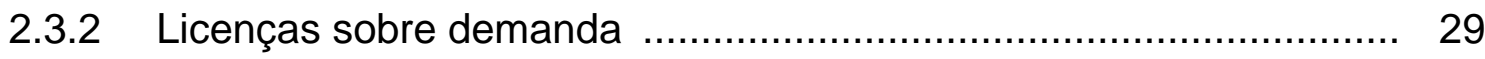

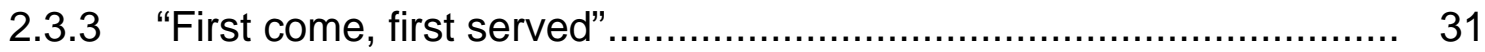

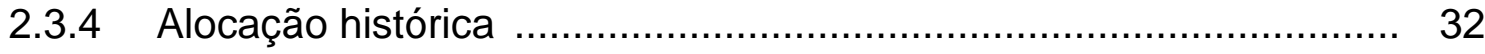




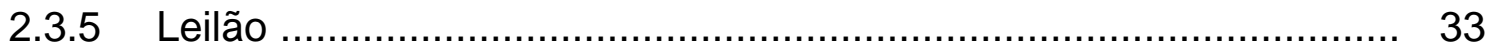

2.3.6 Empresas estatais .............................................................. 34

2.3.7 Grupos de produtores ..................................................... 35

2.3.8 Combinação de métodos e métodos não especificados ................. 36

2.3.9 Condições adicionais ............................................................. 36

2.3.9.1 Limite de participação de mercado................................................ 36

2.3.9.2 Performance comercial passada .............................................. 37

2.3.9.3 Exigência de compras domésticas ............................................. 37

2.3.9.4 Certificados de exportação...................................................... 37

2.4 Alguns aspectos legais sobre as quotas tarifarias ....................... 38

2.4.1 Leis e instituições internacionais de comércio ............................... 38

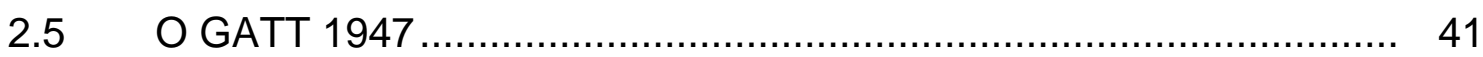

2.5.1 Princípio da não-discriminação ............................................... 42

2.5.2 Transparência ................................................................. 47

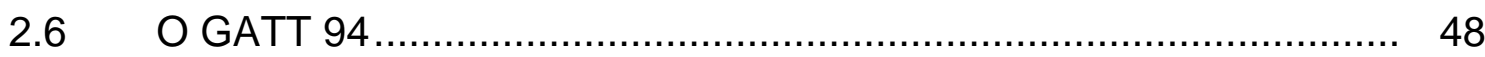

2.6.1 Acesso aos mercados no AARU e GATT 1994 …........................ 49

2.7 Exceções ao princípio de não-discriminação .................................. 54

2.7.1 Acordos preferenciais........................................................... 55

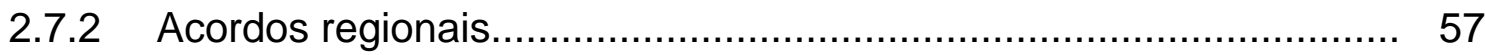

2.8 Princípios do GATT, acesso aos mercados e quotas tarifárias........ 58

2.9 Impressões sobre as quotas tarifarias......................................... 61

3 AS QUOTAS TARIFÁRIAS E A EXPORTAÇÃO AGROINDUSTRIAL BRASILEIRA ............................................... 64

3.1 A utilização das quotas tarifárias no mundo .................................. 65

3.2 As quotas tarifárias e o Brasil................................................... 76

3.3 Os produtos de maior interesse ao Brasil ...................................... 77

3.4 A incidência de quotas tarifárias ................................................ 80

3.5 Os países que impõem quotas tarifárias ..................................... 82

3.6 O comportamento dos componentes das quotas tarifárias ............. 84

3.7 Uma análise país-produto ….................................................... 93 
3.8 Países da Área de Livre Comércio da América do Norte (NAFTA).. 95

3.9 Países da comunidade andina .................................................... 99

3.10 Países centro-americanos e do Caribe ......................................... 102

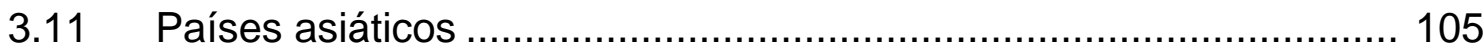

3.12 Países do leste europeu........................................................ 108

3.13 Noruega e Islândia .................................................................... 113

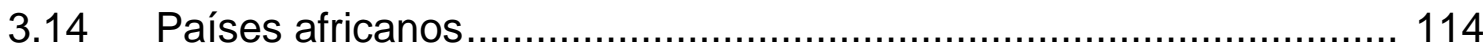

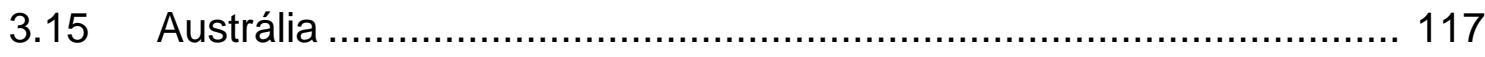

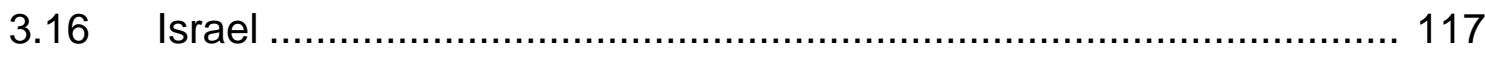

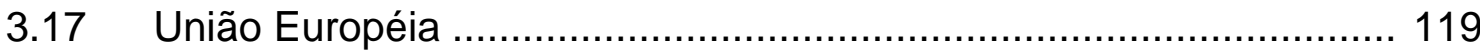

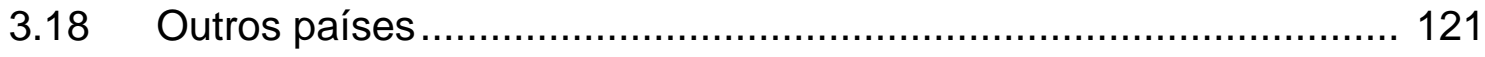

3.19 Indonésia, Japão, Nova Zelândia e Suíça....................................... 121

3.3 Uma discussão sobre a adoção de quotas tarifárias em 26 países

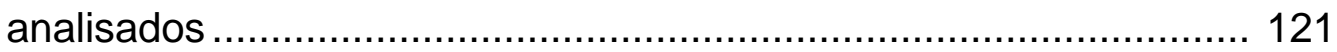

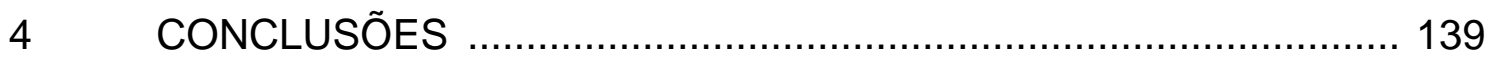

4.1 Considerações sobre futuros trabalhos ......................................... 149

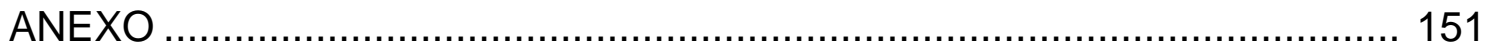

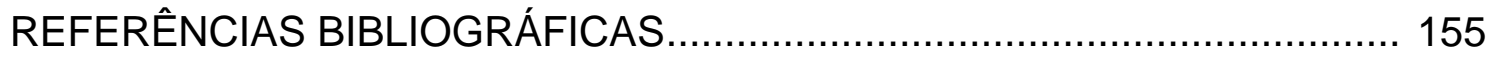




\section{LISTA DE FIGURAS}

Página

1 Sistema de quotas tarifárias: regime intraquota ................................. 17

2 Sistema de quotas tarifárias: implicações do regime intraquota ............... 18

3 Sistema de quotas tarifárias: regime extraquota................................... 20

4 Sistema de quotas tarifárias: implicações do regime extraquota .............. 21

5 Sistema de quotas tarifárias: regime quota ........................................ 23

6 Sistema de quotas tarifárias: implicações do regime quota..................... 24 


\section{LISTA DE TABELAS}

Página

1 Preenchimento de quota por países em desenvolvimento ................... 26

2 Número de quotas tarifárias por país membro da OMC ...................... 66

3 Distribuição das quotas tarifárias pelos principais métodos de administração, período 1995-2001 …............................................... 68

4 Distribuição média do preenchimento das quotas tarifárias pelos principais métodos de administração (média simples), período 19952000, em porcentagem (\%)

5 Distribuição média do preenchimento das quotas tarifárias por método de administração, por faixa porcentual, Ano 2001.............................. 72

6 Número de quotas tarifárias com preenchimento igual ou acima de 100\%, por método de administração, ano 2001

7 Número de quotas tarifárias por capítulo do sistema harmonizado da OMC, ano 2001

8 Principais produtos do agroindustriais da pauta exportadora brasileira: média 2000-2002, número de quotas tarifárias por produto e taxa de preenchimento mundial de quotas (\%)

9 Número de quotas tarifárias para os principais produtos brasileiros, ano 2001.

10 Preenchimento de quotas tarifárias por produto e faixa de

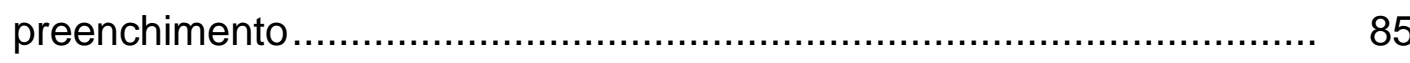

11 Tarifas médias intraquota e extraquota por produto ........................... 88 
12 Distribuição de quotas tarifárias por método de administração e por produto

13 Informações sobre produtos agroindustriais de interesse ao Brasil sujeitos a quotas tarifárias na Área de Livre Comércio da América no Norte (NAFTA)

14 Informações sobre produtos agroindustriais de interesse ao Brasil sujeitos a quotas tarifárias em países sul-americanos

15 Informações sobre produtos agroindustriais de interesse ao Brasil sujeitos a quotas tarifárias em países centro-americanos e do Caribe .. 103

16 Informações sobre produtos agroindustriais de interesse ao Brasil sujeitos a quotas tarifárias em países asiáticos.

17 Informações sobre produtos agroindustriais de interesse ao Brasil sujeitos a quotas tarifárias em países do leste europeu.....

18 Informações sobre produtos agroindustriais de interesse ao Brasil sujeitos a quotas tarifárias na Noruega e Islândia.

19 Informações sobre produtos agroindustriais de interesse ao Brasil sujeitos a quotas tarifárias em países africanos

20 Informações sobre produtos agroindustriais de interesse ao Brasil sujeitos a quotas tarifárias na Austrália

21 Informações sobre produtos agroindustriais de interesse ao Brasil sujeitos a quotas tarifárias em Israel

22 Informações sobre produtos agroindustriais de interesse ao Brasil sujeitos a quotas tarifárias na União Européia

23 Taxa de preenchimento médio e níveis tarifários médios por método de administração

24 Exportações agroindustriais brasileiras, ranking de principais países importadores, ano 2002

25 Síntese da adoção do sistema de quotas tarifárias: principais países e produtos 
26 Performance exportadora brasileira de produtos agroindustriais sujeitos a quotas tarifárias, período 2000-2002 ................................ 134 


\section{LISTA DE ABREVIATURAS}

AARU - Acordo sobre Agricultura da Rodada Uruguai

AMAD - Agricultural Market Access Database

COMTRADE - United Nations Trade Data System

EAV - Equivalente Ad Valorem

EE - $\quad$ Empresa Estatal (método de administração de quotas tarifárias)

ERS - Economic Research Service of USDA

FC - $\quad$ First Come-First Served (método de administração de quotas tarifárias)

GATS - Acordo Geral sobre Comércio de Serviços

GATT - Acordo Geral sobre Tarifas e Comércio

GP - Grupo de Produtores (método de administração de quotas tarifárias)

$\mathrm{HI}$ - $\quad$ Alocação Histórica (método de administração de quotas tarifárias)

LD - $\quad$ Licenças sobre Demanda (método de administração de quotas tarifárias)

LE - $\quad$ Leilão (método de administração de quotas tarifárias)

NMF - Nação-mais-favorecida

OMC - Organização Mundial do Comércio

TA - $\quad$ Tarifa Aplicada (método de administração de quotas tarifárias)

TRAINS - Trade Analysis and Information System da UNCTAD

TRIPS - Acordo de Comércio Relacionado aos Direitos de Propriedade Intelectual

USDA - Departamento de Agricultura dos Estados Unidos (U.S. Department of Agriculture)

WTO - World Trade Organization (Organização Mundial do Comércio) 


\title{
AS QUOTAS TARIFÁRIAS E O ACESSO DE PRODUTOS AGROINDUSTRIAIS BRASILEIROS AO MERCADO INTERNACIONAL
}

\author{
Autor: JOAQUIM HENRIQUE DA CUNHA FILHO \\ Orientador: Prof. Dr. MARCOS SAWAYA JANK
}

\section{RESUMO}

O presente estudo visa a discutir a influência do sistema de quotas tarifárias sobre as exportações agroindustriais brasileiras. Para tanto, descreve o funcionamento e as características das quotas tarifárias e aponta algumas inconsistências em relação aos princípios de não-discriminação e transparência, do sistema GATT/OMC, e perante o compromisso de acesso mínimo e corrente proposto no Acordo sobre Agricultura da Rodada Uruguai (AARU). Por meio de ilustrações gráficas, o presente trabalho demonstra os fatores condicionantes e os efeitos sobre o bem-estar, desvio de renda e possíveis impactos sobre a demanda por importação. Cabe salientar que as ilustrações gráficas desta pesquisa são caracterizadas como seu instrumental metodológico, enquanto a teoria microeconômica e a economia internacional compõem seu arcabouço teórico. Além disso, foram escolhidos como mais importantes, 32 produtos agroindustriais da pauta exportadora brasileira, o que resultou na análise de 352 dentre 1.425 quotas tarifárias, compreendendo 26 dos 43 países que impõem este sistema às suas importações. Os resultados apontaram para uma interferência do sistema de quotas tarifárias sobre a $\begin{array}{llll}\text { exportação agroindustrial } & \text { brasileira. } & \text { Não } & \text { puderam }\end{array}$ 
demonstrar, porém, de forma conclusiva, os efeitos esperados de uma política de liberalização comercial, por caracterizarem-se de forma muito diferenciada, país a país e produto a produto. No entanto, pode-se verificar a influência política e social sobre a administração das quotas tarifárias, seu assentamento legal e institucional frente aos acordos de comércio internacional, suas formas de discriminação, a falta de transparência no uso do sistema e a indicação de que as quotas tarifárias são um instrumento de grande ajuda no controle da oferta doméstica, sendo fundamentais na manutenção de políticas de subsídios e apoio interno. Verificou-se também que as quotas tarifárias influenciam, principalmente, as exportações brasileiras de açúcar, carnes, milho, cacau, tabaco e algodão, para os principais mercados mundiais. Dadas estas nuances, o presente trabalho oferece algumas sugestões aos negociadores brasileiros no que tange ao tratamento conferido ao sistema de quotas tarifárias, para que se consiga maior acesso para produtos agroindustriais brasileiros no mercado internacional. 


\title{
TARIFF-RATE QUOTAS AND INTERNATIONAL MARKET ACCESS TO BRAZILIAN AGRICULTURAL PRODUCTS
}

\author{
Author: JOAQUIM HENRIQUE DA CUNHA FILHO \\ Adviser: Prof. Dr. MARCOS SAWAYA JANK
}

\section{SUMMARY}

The present study aims at discussing the influence of the tariff-rate quota system on Brazilian agricultural exports. The text describes the characteristics of the tariff-rate quota system and points to its inconsistencies with the principles of non-discrimination and transparency prescribed by the General Agreement on Tariffs and Trade (GATT) and the minimum and current access compromises established in the Uruguay Round Agreement on Agriculture (URAA). The present study utilizes graphic illustrations to demonstrate the possible effects of tariff-rate quotas on general welfare, income diversion, and import demand. While graphic illustrations constitute the methodological instruments of the study, the theoretical analysis is drawn from microeconomics and international economics. The study focuses on 32 products that were identified as the most important Brazilian agricultural exports. This resulted in the investigation of 352 out of the total 1,425 tariff-rate quotas, and involved 26 of the 43 countries that impose this type of instrument on their imports. The results point to the interference of the tariff-rate quota system on Brazilian agricultural exports. However, given that the tariff-rate quota mechanisms vary considerable from product to product, and from country to 
country, the results are not conclusive in regards to the effects of adopting trade liberalization policies. The study verifies the influence of political and social factors on the administration of tariff-rate quotas, their legal and institutional standing in international trade agreements, the types of discrimination they perpetuate, their lack of transparency, and the fundamental role they play in the control of domestic supply and maintenance of domestic support policies. Furthermore, the study verified that tariff-rate quotas have a greater influence on Brazil's exports of sugar, meats, corn, cocoa, tobacco, and cotton. Given these nuances, the present study provides Brazilian negotiators with suggestions regarding the treatment of the tariff-rate quota system in order to grant greater access for Brazil's agricultural products in the international market. 


\section{INTRODUÇÃO}

As quotas tarifárias são um instrumento de política comercial utilizadas para a proteção da agricultura em âmbito mundial. Embora existam desde o século XIX, sua expressiva utilização atualmente se deve ao Acordo sobre Agricultura da Rodada Uruguai $(A A R U)^{1}$, última rodada de negociações multilaterais de comércio do Acordo Geral sobre Tarifas e Comércio (GATT) ${ }^{2}$, finalizada em 1994.

O sistema de quotas tarifárias resultou do processo denominado "tarificação"33 e é considerado uma medida de ampliação de acesso a mercados. Consiste na imposição simultânea de duas tarifas, uma quota de importação e um método de distribuição de direitos de importação. Sua aplicação decorre da cobrança de uma tarifa reduzida sobre as importações - denominada de intraquota. Essa tarifa é cobrada até que o volume da quota de importação seja alcançado. Sobre as importações que excederem esse volume, é cobrada outra tarifa, maior que a primeira - denominada extraquota. É ainda adotado um

\footnotetext{
${ }^{1}$ O Acordo sobre Agricultura da Rodada Uruguai (AARU) visa estabelecer um sistema de comércio agrícola justo e orientado para o mercado, compreendendo compromissos específicos para redução e posterior eliminação da proteção em áreas de subsídios domésticos, subsídios à exportação e acesso a mercado, em conformidade com as regras e disciplinas do GATT/OMC. http://www.iconebrasil.org.br/index_glossario_1.asp?idpalavra=25

${ }^{2}$ Acordo Geral sobre Tarifas e Comércio (GATT) é um conjunto de regras e normas de comércio, internacionalmente aceitas. Tem como ideal o livre comércio e, para tanto, assume como parâmetro central de atuação a não-discriminação, por meio da observância das regras da nação-mais-favorecida e do tratamento nacional. http://www.iconebrasil.org.br/ index_glossario_1.asp?idpalavra=22

${ }^{3}$ Tarificação foi o processo de transformação de barreiras não-tarifárias em tarifas utilizado em produtos agroindustriais ao final da Rodada Uruguai, como resultado do Acordo sobre Agricultura. http://www.iconebrasil.org.br/index_glossario_1.asp?idpalavra=149
} 
método de administração que consiste em uma forma de licenciamento das importações limitadas pela quota.

A Organização Mundial do Comércio (OMC), até 2001, registrou quotas tarifárias em 43 países (WTO, 2002), cobrindo 1.425 produtos ou grupo de produtos. Esse número representa cerca de $6 \%$ de todas as linhas tarifárias de produtos agroindustriais existentes (Gibson et al., 2001).

Embora utilizadas em um pequeno número de produtos quando comparadas ao quadro tarifário geral de todos os países signatários da OMC, as quotas tarifárias são aplicadas sobre os produtos mais sensíveis no comércio agrícola, ou seja, aqueles produtos em que realmente os países desejam proteger-se da competição internacional.

As quotas tarifárias, no entanto, podem ser consideradas um entrave às exportações. A literatura existente sobre a sua utilização, entre outros problemas, destaca:

- a complexidade e pouca transparência dos métodos de administração que acabam permitindo que alguns países burlem disciplinas do GATT/OMC e do AARU;

- o viés político e a atuação de fortes lobbies sobre alocação das rendas geradas com a imposição do sistema, atitudes que freqüentemente favorecem a institucionalização da sua alocação para empresas privadas, estatais e para países específicos em detrimento do livre mercado; 
- a consolidação de tarifas extraquota $\mathrm{NMF}^{4}$ em níveis muito altos, às vezes tão altos que impedem qualquer importação além da quota;

- a adoção, em alguns casos, de tarifas intraquota em patamares proibitivos, o que impede a importação;

- a alocação discriminatória e/ou preferencial dos direitos de importação que desvia comércio ${ }^{5}$, prejudicando competidores mais eficientes;

- o não-cumprimento dos volumes de acesso compromissados no AARU;

- o preenchimento reduzido das quotas, reflexo de um sistema complicado e oneroso, que eleva os custos de transação e tornase muito eficiente como método de proteção comercial.

4 NMF significa Nação-mais-favorecida e é uma regra de tratamento não-discriminatório (constante do artigo I do GATT, artigo II do GATS e artigo IV do Acordo de TRIPS) que estabelece a obrigação para um membro da OMC de estender a todos os demais membros da organização a concessão que fizer a um deles. Destarte, caso seja concedido um benefício tarifário a um membro, esse benefício deverá ser estendido a todos os demais. Juntamente com a regra de tratamento nacional (artigo III do GATT), a regra da nação-mais-favorecida é um dos pilares do sistema multilateral de comércio desde 1947. http://www.iconebrasil.org.br/ index_glossario_1.asp?idpalavra=104

${ }^{5}$ Desvio de comércio ocorre quando uma alteração na política comercial favorece o comércio de produtores menos eficientes (de custos de produção mais elevados) em detrimento de produtores mais eficientes (de custos de produção mais baixos) devido à presença de barreiras comerciais. http://www.iconebrasil.org.br/index_glossario_1.asp?idpalavra=189 
É importante destacar que a utilização das quotas tarifárias vem, geralmente, acompanhada de outras formas de proteção. É comum verificar tarifas na forma de tarifas específicas ${ }^{6}$ dentro de um sistema de quotas tarifárias. Essa forma de tarifa pune, em termos relativos, aqueles produtores mais eficientes.

É também comum vincular quotas tarifárias a picos tarifários ${ }^{7}$. A idéia de permitir importação até um determinado montante contribui para a imposição de tarifas extraquota em patamares muito elevados e, como conseqüência, estabelecendo picos tarifários.

Em alguns casos também pode ser verificada a utilização de salvaguardas especiais ${ }^{8}$, medidas sanitárias, fitossanitárias e técnicas concomitantemente ao de quotas tarifárias.

Tangermann (2001) afirma que a difusão das quotas tarifárias após a Rodada Uruguai é a imagem refletida dos altos níveis de proteção na agricultura. Embora possua baixa utilização quando comparado às outras formas de restrição comercial, o sistema de quotas tarifárias é um importante instrumento limitador de acesso aos mercados. É empregado, principalmente, na defesa de commodities de alta sensibilidade política, o que garante ao sistema destaque na formulação das políticas comerciais (Gibson et al., 2001; Abbott, 2001; Herrmann, Kramb e Mönnich, 2000).

As quotas tarifárias, bem como outras formas de proteção ao comércio, são comumente aplicadas na defesa de produtos sensíveis. Muitas

${ }^{6}$ Tarifa específica é uma tarifa expressa em números ou em quantidades específicas por produto, como unidades monetárias por $\mathrm{kg}$, litro, dúzia, unidade, etc. http://www.iconebrasil.org.br/index_glossario_1.asp?idpalavra=147

7 Picos tarifários são tarifas extremamente elevadas aplicadas sobre a importação de um determinado produto. Não há consenso a respeito do nível considerado como pico tarifário, mas várias autoridades sugerem quaisquer tarifas superiores a $15 \%$.

8 Salvaguardas especiais são medidas de proteção para produtos agrícolas previstas pelo Acordo sobre Agricultura da Rodada Uruguai, quando eles sofrem declínio abrupto de preços ou há um aumento repentino de importações em determinado país. 
vezes havendo sobreposição de medidas protecionistas, ou seja, várias formas de proteção aplicadas sobre um mesmo produto. Essa proteção determina uma potencial resistência a qualquer iniciativa de liberalização comercial em negociações bilaterais, sub-regionais, regionais e multilaterais.

O Brasil impõe apenas duas quotas tarifárias, que nunca foram, de fato, usadas. Porém, vários produtos representativos da sua pauta exportadora são diretamente afetados por esse sistema. Os derivados de plantas oleaginosas, o açúcar e seus derivados, as carnes e seus derivados, as frutas e os vegetais, o tabaco, as fibras vegetais - em especial o algodão -, e o café são exemplos de produtos nos quais o Brasil enfrenta quotas tarifárias no mercado internacional.

As exportações agroindustriais brasileiras direcionadas a países que impõem quotas tarifárias atingiram 12,5 bilhões de dólares em 2002, valor que representa $77,5 \%$ das exportações do Brasil vinculadas ao agronegócio. A restrição comercial oriunda da imposição das quotas tarifárias, nesse sentido, impede uma melhor performance comercial brasileira.

Esse é o quadro vislumbrado atualmente sobre a utilização do sistema de quotas tarifárias no mundo e seu efeito sobre as exportações brasileiras. No entanto o País possui uma oportunidade única na sua história comercial: está atuando em três frentes simultâneas, negociando um acordo multilateral - a Rodada de Doha ${ }^{9}$ - e dois regionais - a Alca $^{10}$ e o acordo

\footnotetext{
${ }^{9}$ A Rodada Doha, também chamada "Agenda do Desenvolvimento de Doha" (DDA), é o resultado da IV Conferência Ministerial da OMC, ocorrida em Doha, no Catar, em novembro de 2001. Essa conferência estabeleceu os parâmetros para o início de uma nova rodada de negociações multilaterais de comércio no âmbito daquela Organização. http://www.iconebrasil.org.br/index_glossario_1.asp?idpalavra=130

${ }^{10}$ A Alca (Área de Livre Comércio das Américas) é uma iniciativa de 34 países do continente americano, proposta em 1994, com o objetivo de promover a eliminação de barreiras sobre o comércio e os investimentos na região, de forma gradual e progressiva, porém mantendo políticas comerciais independentes em relação aos países que farão parte do Bloco. As negociações deverão ser concluídas até 2005, de acordo com o cronograma atual. http://www.iconebrasil.org.br/index_glossario_1.asp?idpalavra=45
} 
birregional entre União Européia e Mercosul ${ }^{11}$. Esses são os fóruns ideais para a discussão e alteração de políticas protecionistas que afetam diretamente o acesso de produtos brasileiros aos mercados internacionais. Nesse contexto, a discussão e o estudo das quotas tarifárias tornam-se pertinentes às necessidades brasileiras para o conhecimento dos mecanismos de política comercial adotados por diversos países no mundo.

O presente trabalho é motivado, portanto, pela necessidade de conhecer detalhadamente como, quais produtos e quais mercados restringem o acesso de produtos agroindustriais brasileiros por meio de quotas tarifárias. É motivado também pela quase inexistência de literatura específica sobre as quotas tarifárias no Brasil, seu surgimento, suas características, sua difusão e utilização, além da necessidade urgente de informações precisas sobre a aplicação do sistema no mundo e sua influência nas exportações brasileiras para os diferentes mercados.

\subsection{Objetivo}

Este trabalho tem dois objetivos centrais:

Primeiro: descrever o funcionamento e as características inerentes ao sistema de quotas tarifárias, apontando as suas inconsistências diante dos princípios de não-discriminação e transparência do GATT/OMC e perante o compromisso de acesso mínimo e corrente proposto no Acordo sobre Agricultura da Rodada Uruguai (AARU);

\footnotetext{
${ }^{11}$ O Acordo União Européia-Mercosul é um acordo, ainda em processo de negociação, de associação que tem por finalidade o estabelecimento de uma ampla parceria política e econômica entre as duas regiões, assente em três pilares, designadamente, o diálogo político, a cooperação e um capítulo comercial. http://www.iconebrasil.org.br/ index_glossario_1.asp?idpalavra=33
} 
Segundo: levantar os produtos agroindustriais da pauta exportadora brasileira mais afetados por quotas tarifárias, apontando possíveis alternativas para promover maior acesso desses produtos aos mercados internacionais.

\subsection{Metodologia}

Para apontar o funcionamento e as características inerentes ao sistema de quotas tarifárias, este trabalho fará uso de ilustrações gráficas, no intuito de demonstrar, os condicionantes e efeitos sobre o bem-estar, desvio de renda e possíveis impactos sobre a demanda por importação.

Nesse intento, este trabalho vai discutir os efeitos de medidas de liberalização de comércio dentro do sistema de quotas tarifárias, ou seja, discutir os efeitos da redução de níveis tarifários intra e extraquota ou do aumento de volume das quotas. Serão verificados quais os efeitos sobre a arrecadação do governo, a renda do importador, os ganhos ou perdas de consumidores e produtores, as potenciais melhorias na eficiência do setor na economia e finalmente se há ou não maior acesso a mercado.

Cabe salientar que as ilustrações gráficas deste presente trabalho são caracterizadas como seu instrumental metodológico e têm-se a teoria microeconômica e a economia internacional como arcabouço teórico.

Os métodos de administração e condições adicionais serão descritos à luz dos aspectos legais acordados no GATT/OMC e AARU, buscando-se encontrar problemas relacionados aos conceitos de não-discriminação, transparência e compromisso de acesso mínimo e corrente. Para tanto, será necessária uma revisão de literatura sobre esses tópicos. Essa revisão é fundamental para mostrar a influência da legislação vigente sobre as condições de acesso a mercado dentro de um sistema de quotas tarifárias e demonstrar como a legislação, ratificada pelos países signatários dos acordos de comércio, 
coloca-se em função dos ideais protecionistas em detrimento de princípios de livre comércio aceitos anteriormente.

A segunda parte deste trabalho vai realizar um levantamento dos principais produtos agroindustriais da pauta exportadora brasileira afetados por quotas tarifárias, em todos os países que as impõem. Para isso, será montado um banco de dados contendo as tarifas intraquota e extraquota aplicadas por quotas tarifárias, o volume acordado de cada quota, a taxa de preenchimento da quota desde sua implantação em 1995 e os métodos de administração registrados na OMC para cada quota tarifária.

Por meio da construção e descrição de tabelas explicativas e algumas estatísticas simples, pretende-se demonstrar a adoção das quotas tarifárias nos diferentes mercados mundo afora. A partir das informações sobre os métodos de administração, pretende-se verificar aqueles mais utilizados e sua taxa de preenchimento, buscando identificar um comportamento comum entre método aplicado e preenchimento da quota.

Uma vez identificados os principais produtos agroindustriais da pauta exportadora brasileira, será calculada a tarifa média intraquota e extraquota de cada produto, buscando identificar aqueles que possuem tarifas mais elevadas e, portanto, caracterizando-se como os mais protegidos. Para tanto, este trabalho adotará, nos casos em que houver necessidade, um processo de transformação de tarifas específicas em tarifas ad valorem. Esse procedimento será oportunamente detalhado no presente trabalho.

Serão construídas outras tabelas, visando verificar a distribuição dos métodos de administração para cada produto identificado como importante e seu paralelo com o país que os impõe.

Este trabalho procurará formar um quadro geral de como as quotas tarifárias afetam o acesso de produtos agroindustriais brasileiros no exterior. 
Entretanto ainda será necessário verificar, país a país, como e quais produtos utilizam o sistema. Nesse caso, uma análise de cada nação será realizada, buscando identificar características intrínsecas a cada produto e ao país que impõe a quota tarifária. Para isso, será montada uma tabela para cada nação escolhida contendo o número de quotas tarifárias impostas por produto e seu respectivo método de administração, as tarifas intraquota e extraquota aplicadas, a taxa média de preenchimento da quota, o volume da quota e uma indicação da ocorrência de exportação brasileira destinadas a estas nações. Estas tabelas serão ainda organizadas conforme sua localização geográfica ou bloco comercial ao qual já pertençam.

Por fim, buscando comparar a adoção do sistema de quotas tarifárias entre diversos países, será construída uma tabela resumo contendo as nações e os produtos de maior interesse ao Brasil, as tarifas aplicadas, o tamanho das quotas e o nível de preenchimento. Assim, acredita-se que, ao estruturar esse conjunto de informações, possa-se reconhecer a real influência das quotas tarifárias sobre as exportações brasileiras.

\subsection{Estrutura do trabalho}

O trabalho propõe-se a apresentar, no capítulo 2, por meio de uma revisão, o conceito, as características e a finalidade do sistema de quotas tarifárias, como proposto ao final da Rodada Uruguai do GATT, bem como apresentar as inconsistências desse sistema diante dos princípios de nãodiscriminação, transparência e do compromisso de acesso aos mercados.

Nesse intuito será descrito um breve histórico, no tocante ao surgimento, à ampliação e aplicação desse sistema como forma de proteção comercial. Posteriormente, pretende-se caracterizar mediante ilustrações gráficas os diversos regimes que as quotas tarifárias podem assumir, juntamente com seus efeitos sobre o bem-estar. 
Logo em seguida, apresentar-se-ão os métodos de administração e as condições adicionais, apontando os entraves e as inconsistências desses métodos frente ao argumento de livre comércio defendido pela Organização Mundial do Comércio (OMC). Para tanto, será realizada uma descrição dos princípios de não-discriminação e transparência do GATT e do compromisso de acesso mínimo e corrente do AARU, ou seja, uma discussão sobre pontos legais e institucionais conflitantes oriundos da adoção de quotas tarifárias.

No capítulo 3 será apresentada uma descrição da aplicação do sistema de quotas tarifárias por intermédio de uma síntese dos documentos oficiais notificados na OMC. Nesse capítulo ainda serão verificadas as possíveis correspondências entre os métodos de administração utilizados, níveis tarifários e preenchimento da quota.

Posteriormente, no mesmo capítulo, este trabalho vai apontar as quotas tarifárias que afetam os principais produtos agroindustriais da pauta exportadora brasileira, procurando mostrar algumas formas de alcançar maior acesso a mercado, para, finalmente, concluir este trabalho no capítulo 4. 


\section{SISTEMA DE QUOTAS TARIFÁRIAS: FUNCIONAMENTO, CARACTERÍSTICAS E INCONSISTÊNCIAS}

O primeiro relato sobre as quotas tarifárias reporta-se ao ano de 1839, na Bélgica, que impôs o sistema ao aço importado de Luxemburgo.

Embora as quotas tarifárias não tenham sido amplamente utilizadas quando comparadas aos sistemas tarifários puros ou os sistemas de quotas puros, até os anos da Grande Depressão, foram bastante populares.

Durante a Grande Depressão, o sistema foi sendo substituído por quotas puras ou sistemas tarifários puros. Em 1937, somente a Suíça empregava quotas tarifárias em grande escala, porém, após a Segunda Grande Guerra, elas foram abandonadas e substituídas por outras formas de barreiras comerciais (Skully, 2000).

Em 1995, como resultado do AARU, as quotas tarifárias voltam a possuir expressão no comércio internacional, sendo utilizadas no comércio mundial de produtos agrícolas e agroindustriais, cobrindo aproximadamente 6\% das linhas tarifárias ${ }^{12}$ de todas as commodities agrícolas. Até 2001 , as quotas tarifárias correspondiam a 1.425 produtos ou grupo de produtos, sendo adotadas por 43 países $^{13}$, todos signatários da OMC (Gibson et al., 2001).

\footnotetext{
${ }^{12}$ Linhas tarifárias definidas pelo Sistema Harmonizado (harmonized system - HS) da OMC.

${ }^{13}$ WTO Secretariat, documento TN/AG/S/5 de 22/3/2002.
} 
Cabe destacar que a Rodada Uruguai foi concluída em abril de 1994 e, entre suas principais contribuições, está a criação da Organização Mundial do Comércio (OMC), que substituiu o GATT, como o órgão internacional legal e institucional que controla, promove e administra os fundamentos do sistema multilateral de comércio entre seus diversos países membros. A OMC incorporou e passou a gerir também alguns temas não compreendidos pelo GATT, como serviços e propriedade intelectual, entre outros.

Outra importante contribuição da Rodada Uruguai foi a promoção de um acordo sobre agricultura, acordo que até então não havia obtido grandes progressos em rodadas de negociações multilaterais anteriores (Skully, 2000a).

O AARU foi proposto para disciplinar o comércio e as políticas domésticas relacionadas à agricultura e às negociações globais para redução de barreiras ao comércio agrícola. Uma das proposições do AARU é a de que todas as "restrições quantitativas" sobre importação agrícola devessem ser abolidas, podendo ser convertidas para a forma de tarifas ad valorem ou tarifas específicas. Esse processo ficou conhecido como "tarificação" (Morath, 1997).

O processo de tarificação encontrou, no entanto, uma grande dificuldade na sua aplicação. As barreiras quantitativas mais elevadas determinavam fatalmente tarifas extremamente altas, que, por sua vez, impediam completamente ou proporcionavam um volume de comércio menor do que aquele anterior à medida.

Entretanto, para que houvesse maior acesso aos mercados, no AARU também ficou estabelecido um compromisso de acesso mínimo, de forma que seus países signatários passariam a garantir a importação de, pelo 
menos, $3 \%$ do seu consumo doméstico ${ }^{14}$, tendo por período-base os anos de 1986, 1987 e 1988. Ficou compromissada também a elevação desse porcentual para 5\% até 2000 (2004 para países em desenvolvimento).

Um impasse foi, portanto, criado. A presença de elevadas tarifas não permitiria que o compromisso de acesso fosse cumprido. A solução se deu com a utilização de um instrumental que envolve elementos de quotas e de tarifas, um sistema que pode ser interpretado como um passo intermediário para a conversão de restrições quantitativas em tarifas. Esse sistema, conhecido como "quotas tarifárias", ou, do termo em inglês, "tariff-rate quotas", além de ser constituído por tarifas, garante a condição de acesso mínimo acordada (Skully, 2001a).

As quotas tarifárias consistem na imposição simultânea de duas tarifas, uma quota de importação e um sistema de distribuição de direitos de importação. Sua aplicação decorre da cobrança de uma tarifa reduzida, a tarifa intraquota (in-quota tariff), às importações até que seja alcançado o volume da quota. Às importações que excedem esse volume é cobrada uma tarifa mais elevada, tarifa extraquota (over-quota tariff). Além disso, há um método de administração de distribuição de direitos de importação (Abbott, 2001; WTO, 1995).

\footnotetext{
${ }^{14}$ O compromisso de acesso mínimo, segundo Bureau (1999), foi estabelecido a partir de grupos de produtos e não por linha tarifária específica. Nesse sentido, aponta o autor, muitos países foram oportunistas quanto ao cálculo do volume de acesso mínimo e, como conseqüência, nos volumes alocados às quotas tarifárias. Dessa forma conseguem importar maior quantidade de determinados produtos, compensando a pouca importação de produtos sensíveis no atendimento ao compromisso de acesso.
} 


\subsection{O sistema de quotas tarifárias}

A literatura internacional sobre as quotas tarifárias, em termos teóricos, ainda não é consensual quanto ao tipo de restrição que esse sistema representa, ou seja, se é ou não uma restrição quantitativa.

Skully (2001a) propõe que as quotas tarifárias, como fruto do processo de tarificação, não podem ser consideradas um tipo de restrição quantitativa por não limitar a quantidade de importação. Sempre há a possibilidade de importação pagando-se a tarifa extraquota. O autor defende, nesse sentido, que o sistema de quotas tarifárias promove maior acesso aos mercados quando comparado ao sistema de quotas puro.

$\mathrm{Na}$ prática, no entanto, existe um consenso. Conforme apontam Skully (2001a, 2001b), Abbott (2001), Gibson et al. (2001), Morath (1997), DeGorter e Sheldon (2001), em geral as tarifas extraquota são tão altas que efetivamente excluem qualquer possibilidade de importação superior à quota. $O$ que gera, portanto, o mesmo efeito de um sistema de quotas puro, ou seja, o mesmo efeito de uma restrição quantitativa por definição.

Ainda como concordância, segundo apontam Gibson et al. (2001) e Abbott (2001), as quotas tarifárias são utilizadas, principalmente, para proteção de commodities de alta sensibilidade política, e, nesse sentido, possuem importante papel de proteção no comércio agrícola internacional.

Embora o sistema faça parte de um acordo multilateral global e, portanto, de aceitação ampla, em muitos casos seus elementos ferem princípios e disciplinas do GATT/OMC e do AARU. Isso torna o tema polêmico e conflitante.

A distribuição dos direitos de importação, por exemplo, é um típico elemento problemático apontado na literatura. Abbott (2001), Skully (2001a, 
2001b), Gibson et al. (2001) e Morath (1997), entre outros, já discutiram a pouca transparência no processo de distribuição e administração desses direitos de importação.

Esses métodos influenciam a distribuição de renda (rents), rendas adicionais advindas da aquisição de um produto no mercado mundial ao preço mundial e revendido no mercado doméstico (protegido) com preço mais elevado. A restrição de oferta oriunda da imposição das quotas tarifárias aliada à forte demanda interna faz com que o preço doméstico se eleve, proporcionando um ganho - o rent - maior ao importador. Esses rendimentos podem promover as pressões de grupos domésticos ou países exportadores favorecidos, o que pode proporcionar desvio de comércio (Skully, 2001a).

Cada método de administração, como discutido na literatura, possui características próprias e graus diferenciados de proteção e inconsistências perante as disciplinas de comércio multilateral. Inúmeras são as interpretações sobre suas regras e isso vem gerando uma gama considerável de disputas comerciais.

Atualmente são sete os métodos de administração registrados na OMC: tarifa aplicada, licenças sobre demanda, first come-first served, alocação histórica, leilão, empresas estatais e grupo de produtores. Esses métodos serão apresentados posteriormente neste trabalho.

Outro problema que merece destaque, discutido em Jackson, Davey e Sykes (1995) e DeGorter \& Sheldon (2001), é a eliminação geral das restrições quantitativas proposta tanto no GATT como no AARU. Embora proibidas, inúmeras exceções foram estabelecidas. Entre elas, a instituição de quotas tarifárias para produtos agrícolas. Isso é conflitante, conforme afirmam Hoekman e Kostecki (2001), com a proposição defendida pelo GATT de que a imposição de tarifas é o único instrumento de proteção permitido e de consistência econômica. 
Embora apresentando vários problemas e inconsistências, no cenário internacional, as quotas tarifárias são consideravelmente utilizadas pelos Estados Unidos, pela União Européia, pelo Japão e pelos membros do Grupo de Cairns - os maiores participantes nas negociações agrícolas na Rodada Uruguai. Além deles, há os exemplos da China e dos países do Leste Europeu que recentemente vêm promovendo seu acesso à OMC e, para tanto, estão usando amplamente o instrumento quotas tarifárias.

Se de um lado há indeterminação de regras claras e risco de desvio de comércio, de outro esse é o ambiente em que se desenvolvem questões de acesso aos mercados e liberalização. Nesse sentido, para minimizar o risco de uma negociação pouco favorável no que tange à aplicação das quotas tarifárias é que se deve, com urgência, estudá-las.

\subsection{Os condicionantes das quotas tarifárias}

Abbott \& Paarlberg (1998) afirmam que as quotas tarifárias afetam a estabilidade do preço mundial e do preço doméstico, e que seu impacto depende das características da demanda doméstica e da forma como ocorrem os ajustes de mercado. Se, por exemplo, a demanda se deslocar suficientemente a ponto de permitir importação acima da quota, a ampliação do acesso pode ser alcançada por meio da redução da tarifa extraquota, ou ainda, do aumento da quota. Outras alterações podem ser realizadas, gerando diferentes resultados.

Uma política de liberalização do sistema deve, portanto, levar em conta as características da demanda doméstica e sua posição relativa diante dos níveis fixados para as tarifas e para o volume da quota.

Os artigos de Abbott (2001), Skully (2001a, 2001b), DeGorter e Sheldon (2001), Tangermann (2001) e Gibson et al. (2001), entre outros, mostram três possíveis regimes do sistema de quotas tarifárias. Dependendo 
da magnitude da demanda líquida por importação, as quotas tarifárias podem agir como um sistema tarifário puro quando existe uma demanda fraca; podem agir verdadeiramente como quota tarifária quando há uma demanda forte; e ainda podem agir como sistema de quotas puro quando existe uma demanda intermediária ou quando a tarifa extraquota é muito elevada.

Essas características expressam que somente um dos instrumentos das quotas tarifárias - tarifa intraquota, tarifa extraquota ou quota - pode ser efetivo na determinação das importações e dos preços domésticos perante o preço mundial.

\subsubsection{Regime intraquota}

Considerando-se um pequeno país importador e uma curva de oferta mundial infinitamente elástica, a efetividade da tarifa intraquota ocorrerá quando o preço mundial acrescido da tarifa intraquota, $\mathrm{P}_{\mathrm{w}}\left(1+\mathrm{t}_{1}\right)$, for maior que o preço doméstico adotado num regime de quotas (Abbott, 2001). Ou seja, quando a demanda por importação, ao preço $P_{w}\left(1+t_{1}\right)$, não for suficientemente forte para preencher a quota. Isso pode ser demonstrado graficamente pela figura 1 (Skully, 2001a).

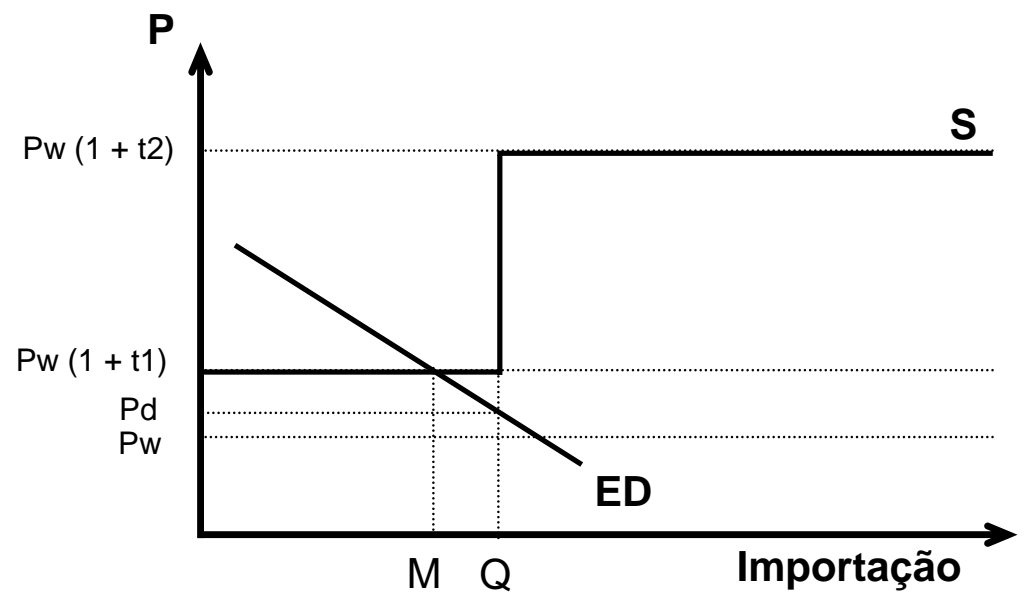

Figura 1 - Sistema de quotas tarifárias: regime intraquota.

Fonte: modificado de Skully (2001a) 
Na figura 1, temos que ED é a curva de excesso de demanda do país importador (sua demanda por importação), S é a curva de oferta mundial, Pw é o preço mundial da commodity, $\mathrm{P}_{\mathrm{w}}\left(1+\mathrm{t}_{1}\right)$ é o preço mundial acrescido da tarifa intraquota, $\mathrm{P}_{\mathrm{w}}\left(1+\mathrm{t}_{2}\right)$ é o preço mundial acrescido da tarifa extraquota, $\mathrm{Pd}_{\mathrm{d}}$ é o preço doméstico sob sistema de quotas puro, Q é o volume estipulado como quota e $M$ é o total importado pelo país dada sua curva de excesso de demanda.

O regime intraquota, segundo Abbott (2001), opera conforme um regime tarifário puro. Carrega consigo, portanto, as implicações de um regime tarifário puro sobre o bem-estar do produtor doméstico e dos consumidores, rendimentos por parte do governo devido à imposição das tarifas, eficiência econômica e rendas adicionais (rents) advindos da utilização do sistema de quotas tarifárias. A figura 2 mostra essas implicações.

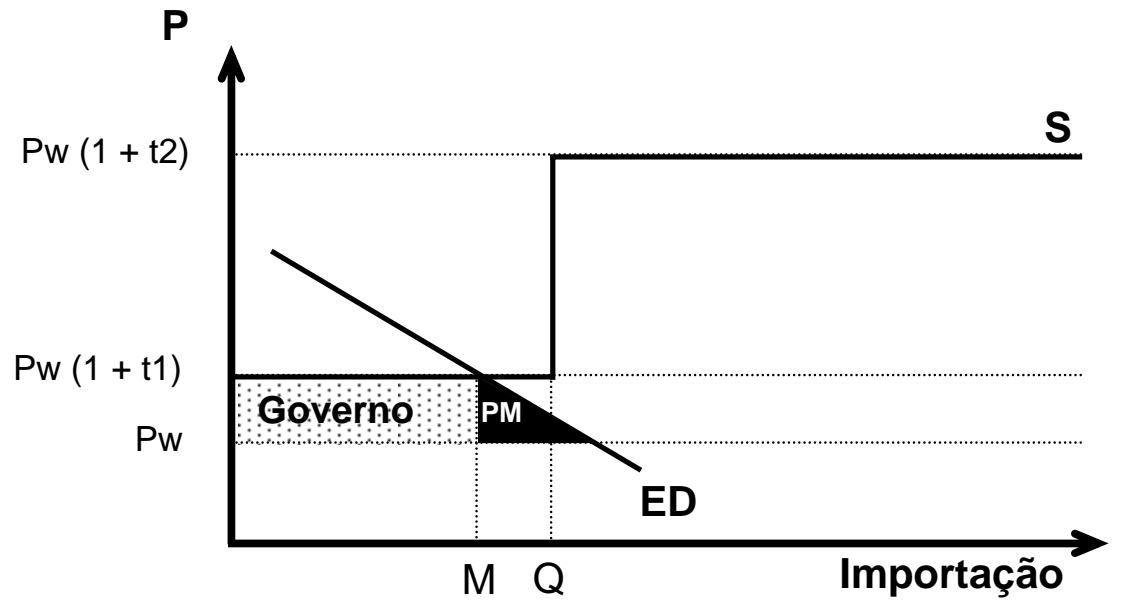

Figura 2 - Sistema de quotas tarifárias: implicações do regime intraquota. Fonte: modificado IATRC (2001)

$\mathrm{Na}$ figura 2, temos que a área denominada Governo representa a arrecadação do governo devido à imposição da tarifa intraquota, e o triângulo 
menor, denominado PM, representa a perda de bem-estar econômico (pesomorto) por parte dos consumidores.

Uma breve constatação pode ser feita para esse regime. Negociações visando a ampliação de acesso ao mercado ou redução de tarifa extraquota não têm efeito no que tange à liberalização comercial. Ou seja, liberalização nesse regime somente ocorrerá com a redução efetiva da tarifa intraquota.

A redução da tarifa intraquota reduziria o nível de preço doméstico e aumentaria a importação por aquela commodity, proporcionando maior acesso ao mercado para países exportadores. Uma vez que se reduz a proteção do mercado, há a redução no bem-estar do produtor doméstico e aumento na eficiência econômica da produção doméstica daquela commodity, já que ocorre a expulsão dos produtores de menor eficiência. A possibilidade de aquisição da commodity a um preço menor acaba elevando o bem-estar do consumidor doméstico.

No que tange à arrecadação governamental, dada a simplicidade do modelo gráfico, não há como especificá-la. Os rendimentos para o governo podem aumentar ou reduzir-se dependendo da elasticidade da curva de excesso de demanda (DeGorter e Sheldon, 2001). De qualquer forma, essas constatações podem representar importantes argumentos para os mais diferentes tipos de negociações comerciais.

\subsubsection{Regime extraquota}

Dadas as mesmas pressuposições do regime intraquota, a efetividade da tarifa extraquota ocorrerá quando o preço mundial acrescido da tarifa extraquota for inferior ao preço doméstico adotado num sistema de quotas puro (Abbott, 2001). Ou seja, existe uma demanda suficientemente forte para 
que as importações ultrapassem a quota estabelecida. A figura 3 ilustra esse regime.

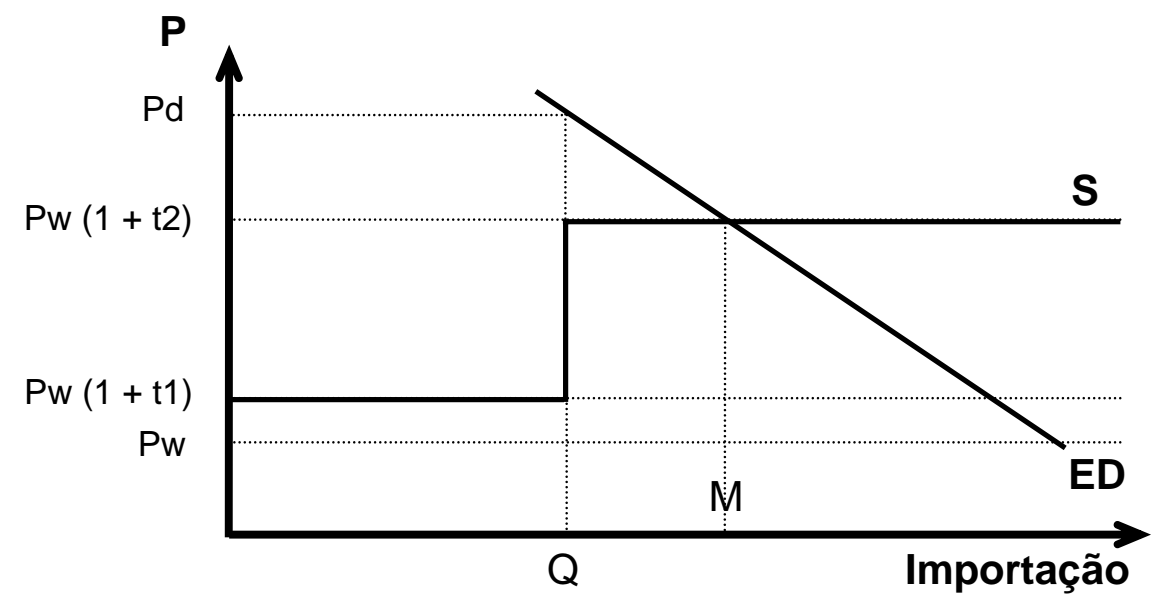

Figura 3 - Sistema de quotas tarifárias: regime extraquota.

Fonte: modificado de Skully (2001a)

Exatamente como no regime intraquota, temos que ED é a curva de excesso de demanda do país importador, S é a curva de oferta mundial, Pw é o preço mundial da commodity, $\mathrm{P}_{w}\left(1+\mathrm{t}_{1}\right)$ é o preço mundial acrescido da tarifa intraquota, $P_{w}\left(1+t_{2}\right)$ é o preço mundial acrescido da tarifa extraquota, $P_{d}$ é o preço doméstico sob sistema de quotas puro, Q é o volume estipulado como quota e $\mathrm{M}$ é o total importado pelo país dada sua curva de excesso de demanda.

No caso em que o regime extraquota é efetivo, segundo Abbott (2001), um método de administração das quotas tarifárias deve ser adotado para alocar as licenças de importação. Esse método é determinante na distribuição das rendas adicionais (rents).

Uma vez que existe a possibilidade de importação pagando-se uma tarifa menor e essa possibilidade depende de um sistema de administração de 
licenças de importação, pode-se considerar esse regime como um sistema de quotas tarifárias propriamente dito.

A figura 4 mostra as implicações em relação ao bem-estar de regime extraquota do sistema de quotas tarifárias.

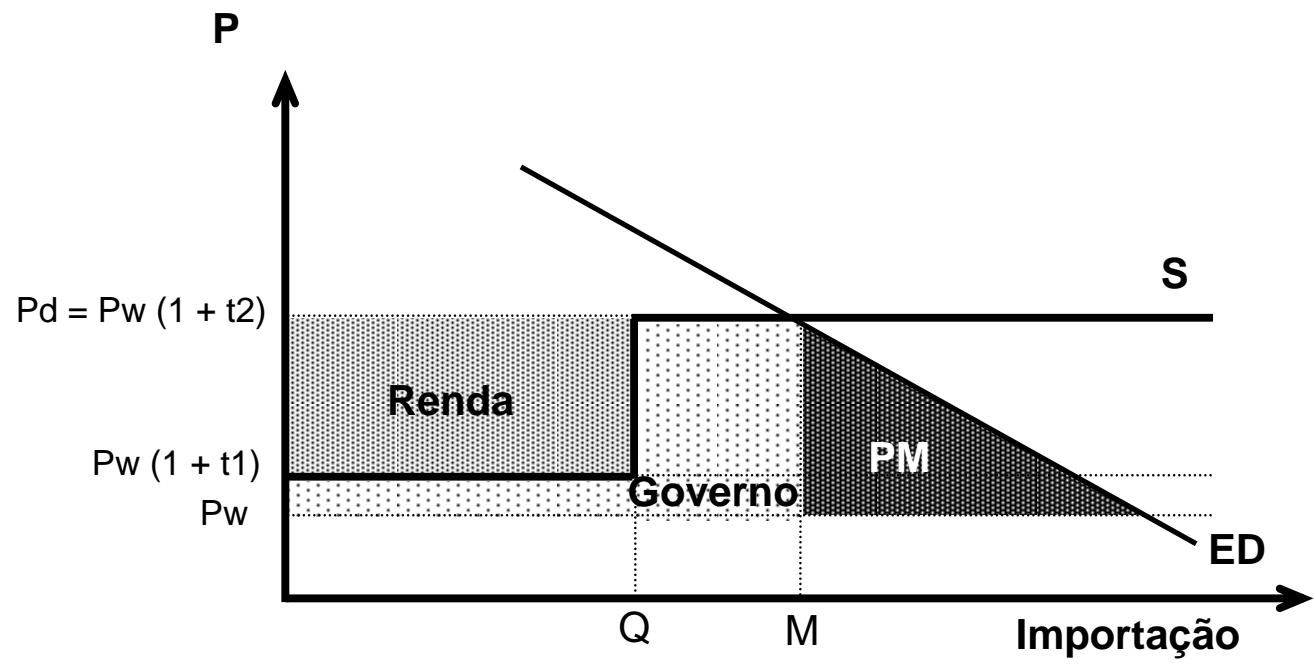

Figura 4 - Sistema de quotas tarifárias: implicações do regime extraquota. Fonte: modificado IATRC (2001)

$\mathrm{Na}$ figura 4, temos que a área denominada governo representa a arrecadação do governo. Note que uma parte da arrecadação deve-se à imposição da tarifa intraquota e outra à imposição da tarifa extraquota. O triângulo denominado PM representa a perda de bem-estar dos consumidores com a utilização do sistema de quotas tarifárias e o retângulo denominado Renda, as rendas adicionais obtidas pelos importadores detentores dos direitos de importação. Estes compram no mercado mundial ao preço $P_{w}\left(1+t_{1}\right)$ e vendem em seu mercado doméstico ao preço $\mathrm{Pw}_{\mathrm{w}}\left(1+\mathrm{t}_{2}\right)$, diretamente influenciados pela forte demanda doméstica pela commodity. 
A liberalização no regime extraquota pode tomar diferentes formas dependendo qual dos instrumentos - tarifa intraquota, tarifa extraquota e a quota - é alterado nas negociações.

A redução na tarifa intraquota vai diminuir os rendimentos por parte do governo, redução que será incorporada à área Renda, ou seja, a arrecadação governamental será transferida para os detentores das licenças de importação.

A redução da tarifa extraquota terá como efeito a diminuição do preço cobrado domesticamente e um aumento na importação da commodity, uma redução no bem-estar do produtor doméstico, cuja perda se converte em ganho para o consumidor daquele país. Uma vez que é reduzida a proteção naquele mercado, aumenta-se a eficiência do setor e diminui-se o montante da renda adicional recebida pelos detentores das licenças de importação - reduzse, portanto, a área denominada Renda. Os rendimentos do governo não podem ser graficamente analisados, pois dependem da elasticidade da curva de excesso de demanda - seu efeito pode ser positivo ou negativo.

Outra medida no sentido de liberalização comercial é o aumento do acesso ao mercado ou aumento da quota. Se esse crescimento superar o volume importado por aquele país, ou seja, a quota tornar-se superior ao volume importado $\mathrm{M}$, ocorrerá uma redução no nível de preço doméstico e um aumento na importação do produto, diminuindo o bem-estar do produtor, redução que é transferida para o consumidor daquele país. Aumenta a eficiência econômica do setor dada a menor proteção e cresce a arrecadação do governo, no que se refere à imposição da tarifa intraquota, e, por sua vez, há uma redução dessa arrecadação no tocante à imposição da tarifa extraquota, não se podendo, portanto, afirmar se ocorrerá aumento ou diminuição na arrecadação total do governo, visto que isso dependerá da elasticidade da curva de excesso de demanda do produto. Outro fator que também não pode 
ser analisado graficamente são as rendas adicionais (rents), pois elas também dependerão da elasticidade da curva de excesso de demanda do país importador.

Porém, se o aumento do acesso ao mercado não superar o volume importado por aquele país, somente ocorrerá a transferência de arrecadação do governo para os detentores das licenças de importação, ou seja, haverá uma renda adicional a eles (rents).

\subsubsection{Regime quota}

Novamente como nos casos anteriores, considerando-se um pequeno país importador e uma curva de oferta mundial infinitamente elástica, a efetividade da quota ocorrerá quando a demanda por importação ao preço mundial acrescida da tarifa intraquota exceder o volume estipulado da quota, e, simultaneamente, a demanda por importação acrescida da tarifa extraquota for menor que o volume estipulado pela quota. Nesse caso, a importação será igual à quota e o preço doméstico será fixado entre os extremos $\mathrm{P}_{\mathrm{w}}\left(1+\mathrm{t}_{1}\right)$ e $\mathrm{P}_{\mathrm{w}}\left(1+\mathrm{t}_{2}\right)$ (Abbott, 2001), conforme demonstrado na figura 5.

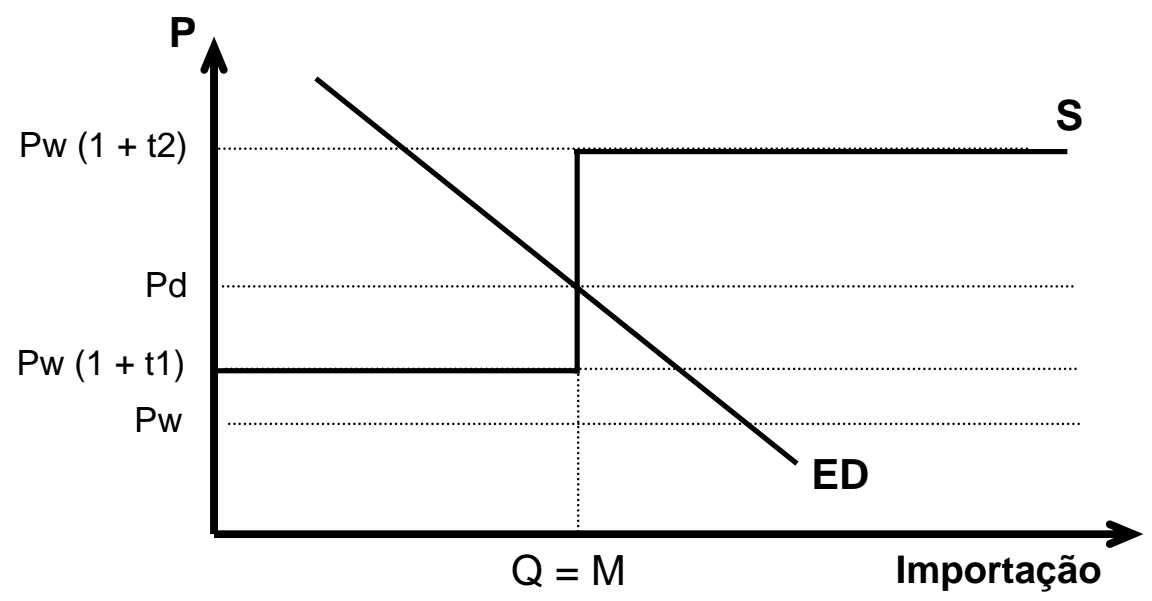

Figura 5 - Sistema de quotas tarifárias: regime quota.

Fonte: modificado de Skully (2001a) 
De novo, como nos demais casos, teremos que ED é a curva de excesso de demanda do país importador (sua demanda por importação), S é a curva de oferta mundial, $\mathrm{P}_{\mathrm{w}}$ é o preço mundial da commodity, $\mathrm{P}_{\mathrm{w}}\left(1+\mathrm{t}_{1}\right)$ é o preço mundial acrescido da tarifa intraquota, $\mathrm{P}_{\mathrm{w}}\left(1+\mathrm{t}_{2}\right)$ é o preço mundial acrescido da tarifa extraquota, $P_{d}$ é o preço doméstico fixado segundo condições domésticas de mercado, Q é o volume estipulado como quota e M é o total importado, nesse caso igual ao volume acordado como quota.

Abbott (2001) aponta que o sistema de quotas tarifárias sob Regime Quota comporta-se como um regime de quota puro, assumindo, portanto, as implicações inerentes a esse sistema no que tange às relações de bem-estar.

$\mathrm{Na}$ figura 6, a seguir, temos novamente que o retângulo Renda representa as rendas adicionais dos importadores que compram no mercado mundial ao preço $\mathrm{P}_{\mathrm{w}}\left(1+\mathrm{t}_{1}\right)$ e, dadas as condições de demanda doméstica, vendem a um preço $P_{d}$ superior a $P_{w}\left(1+t_{1}\right)$. O triângulo menor, denominado $\mathrm{PM}$, representa a perda de bem-estar por parte dos consumidores domésticos.

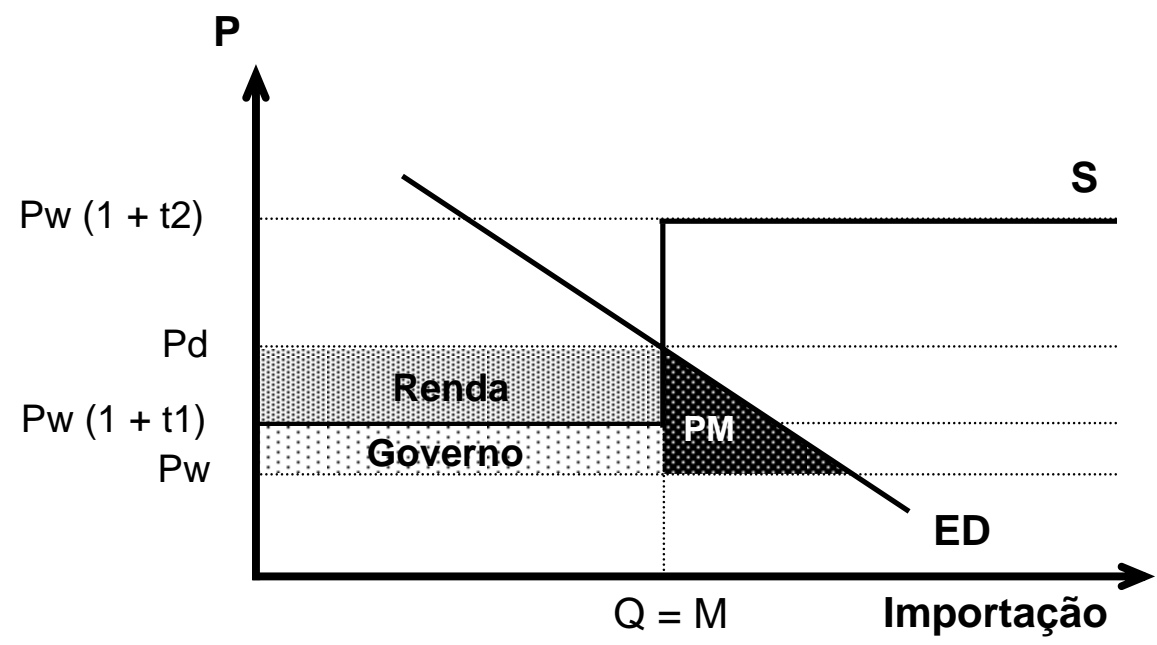

Figura 6 - Sistema de quotas tarifárias: implicações do regime quota.

Fonte: modificado IATRC (2001) 
A liberalização comercial no Regime Quota também possui algumas características próprias e, por isso, algumas medidas são mais efetivas do que outras.

A redução da tarifa intraquota, como no caso do regime extraquota, somente transfere arrecadação do governo para os importadores detentores das licenças de importação.

Uma redução da tarifa extraquota suficiente para que ocorra importação acima do volume da quota teria como efeito a redução do preço doméstico e o aumento do volume importado, diminuição do bem-estar do produtor doméstico e o conseqüente crescimento no bem-estar dos consumidores. A redução de proteção aumenta a eficiência do setor. O governo arrecadaria um montante maior, uma vez que há importação acima da quota, e ocorreria uma redução no valor dos ganhos dos importadores que detêm as licenças de importação.

A outra medida de liberalização comercial seria aumentar o acesso ao mercado, ou seja, expansão da quota. Um caso possível é aquele em que a quota expande além da curva de excesso de demanda, alterando o regime, passando a se comportar como um regime intraquota.

O outro caso possível é a expansão da quota aquém da curva de excesso de demanda. Nesse caso ocorre um aumento do volume importado, redução do bem-estar do produtor doméstico e crescimento do bem-estar dos consumidores. O menor nível de proteção determina maior eficiência do setor. A arrecadação do governo aumenta e não é possível constatar graficamente o efeito sobre as rendas adicionais dos importadores detentores das licenças de importação - dependendo da elasticidade da curva de excesso de demanda, o efeito pode ser positivo ou negativo. 


\subsubsection{Considerações adicionais sobre os regimes das quotas tarifárias}

Uma característica amplamente considerada na literatura é o fato de que as quotas compromissadas podem não ser preenchidas (quota under-fill), podem ser exatamente preenchidas (quota fill) ou ainda podem ser ultrapassadas (quota over-fill), estas características sobre o preenchimento das quotas estão diretamente associadas aos regimes de quotas tarifárias anteriormente discutidos.

Verifica-se que no regime intraquota não ocorre o preenchimento total da quota - logo, ocorre quota under-fill. No regime extraquota o volume importado ultrapassa a quota estipulada - portanto, apresenta uma característica quota over-fill; e no regime quota esta é exatamente preenchida (quota fill).

Abbott (2001) ilustra a incidência de preenchimento dos acordos de acesso para países em desenvolvimento até o ano de 1999, estatísticas calculadas a partir das notificações registradas na OMC, conforme tabela 1.

Tabela 1. Preenchimento de quota por países em desenvolvimento.

\begin{tabular}{lc}
\hline Tipo de preenchimento de quota & Percentual (\%) \\
\hline Casos quota under-fill & $41 \%$ \\
Casos quota over-fill & $38 \%$ \\
Casos quota fill & $21 \%$ \\
\hline
\end{tabular}

Fonte: modificado de Abbott (2001)

Cabe salientar que, de acordo com DeGorter e Sheldon (2001), o não-preenchimento da quota não significa ineficiência (DeGorter e Sheldon, 2001), podendo ser causado por um preço $P_{w}\left(1+t_{1}\right)$ inadequado perante a 
demanda. Nesse caso, a tarifa intraquota pode ter sido estipulada em um valor muito elevado ou simplesmente o país importador não necessita de grandes volumes de importação para a commodity em questão.

Em Abbott (2001) a característica under-fill pode ser ocasionada pelos custos de transação associados ao método de administração da quota tarifária. Uma vez que estes custos de transação sejam muito elevados ou pouco transparentes, podem significar um impedimento ao processo de importação. Nesse caso, uma demanda capaz de preencher ou até ultrapassar a quota, devido aos custos de transação inerentes, é deslocada, causando under-fill.

Nos casos de exato preenchimento da quota de importação, quota fill, cabe ressaltar a importância da distribuição dos direitos de importação, pois, por intermédio deles, importadores podem obter lucros livres de risco comprando no mercado internacional ao preço $\mathrm{P}_{\mathrm{w}}\left(1+\mathrm{t}_{1}\right)$ e vendendo no seu mercado doméstico a um preço superior $P_{d}$. Skully (2001a) diz que nessa situação é que ocorrem as pressões de grupos políticos de forma a influenciar os governos na escolha de um método de administração que proporcione o melhor resultado diante de suas necessidades econômicas e políticas.

A característica quota over-fill dos regimes extraquota indica uma demanda forte pela commodity em questão, o que pode significar uma oportunidade ao países exportadores de liberalização maior desse produto.

Tangermann (2001) afirma que as negociações sobre implementação das quotas tarifárias e seus métodos de administração podem melhorar as condições de acesso dadas as elevadas tarifas cobradas. Essa afirmação determina um alvo propício de avanços nas negociações sobre liberalização, destacando-se de um lado a utilização do instrumento quotas tarifárias e de outro os métodos de administração aplicados. 


\subsection{Métodos de administração}

O comportamento do sistema de quotas tarifárias, como apresentado nas seções anteriores, é determinado pelo formato e tamanho da demanda doméstica. No entanto, Abbott (2001), Bureau (1999), Skully (2001a, 2001b), Hermann, Kramb e Mönnich (2000), Joerin e Lengwiler (2003), Gervais e Surprenant (2000) e DeGorter e Sheldon (2001) discutem a grande influência dos métodos de administração no sistema de quotas tarifárias e sua grande capacidade de distorcer comércio.

A forma como as quotas tarifárias são administradas pode determinar o volume e a distribuição de comércio e, como consequência, determinar a distribuição das rendas adicionais (rents) (Skully 2001a).

Dependendo da maneira como o método distribui o comércio e como alocam as rendas adicionais características da imposição do sistema, segundo Skully (2001b), há como se mensurar a maior ou menor propensão ao desvio de comércio e sua compatibilidade em relação às disciplinas e regras de comércio multilateral.

Os custos de transação envolvidos na administração das quotas tarifárias também são outro fator relevante como instrumento de proteção comercial. Esses custos acabam afetando diretamente a tomada de decisão pela importação (Abbott, 2001). Os custos de transação decorrem, principalmente, do monitoramento de grupos de pressão, do acompanhamento do processo de aquisição das licenças de importação, do acompanhamento das políticas comerciais e da avaliação das condições de mercado mundiais e domésticas. Logo, a adoção de cada método específico traz consigo uma série de vantagens e desvantagens. 


\subsubsection{Tarifa aplicada}

O método de administração de quotas tarifárias denominado tarifa aplicada (applied tariff) consiste em permitir importação ilimitada. Nesse método as importações estão sujeitas somente ao pagamento da tarifa intraquota. A quota e a tarifa extraquota não são exigidas (não ocorre o enforcement de ambas). Como não acontece distribuição de direitos de importação, logo, não ocorre criação de renda adicional (rents). A única medida restritiva é a tarifa intraquota.

Skully (2001a) aponta o método tarifa aplicada como o mais utilizado segundo os registros na OMC, com aproximadamente $47 \%$ de todas as quotas tarifárias, sendo particularmente compostas por produtos pouco sensíveis. Nesse caso, é provável que o preço doméstico seja inferior ao preço mundial, provocando, assim, pouca perturbação no que se refere aos montantes importados diante da produção doméstica.

De acordo com Abbott (2001), o método tarifa aplicada é empregado para simplesmente indicar a presença da quota tarifária nos acordos da OMC. O autor afirma que a utilização desse método pode representar precaução perante a concorrência internacional. Como qualquer método de administração pode ser alterado, se necessário, o governo pode vir a trocá-lo por outro mais protecionista, sem ferir os princípios e acordos do GATT/OMC.

\subsubsection{Licenças sobre demanda}

O método de administração de quotas tarifárias denominado licenças sobre demanda (licenses on demand) consiste na distribuição de licenças de importação como uma função das quantidades solicitadas. Segue um critério de proporcionalidade entre o número de licenças solicitadas e o valor da quota, de forma que, se a soma das quantidades solicitadas exceder a quota, há a redução proporcional no volume de cada licença (Bureau, 1999). No entanto, se 
a demanda por licenças anteriores a sua distribuição não for suficiente para preencher a quota, o sistema geralmente opera como first come, first served (Skully, 2001a).

Skully (2001a) calculou a participação desse método no total de notificações registradas na OMC. O método licenças sobre demanda é utilizado em aproximadamente $25 \%$ delas.

Nesse método uma empresa pode receber uma quantidade inferior à solicitada, característica que incentiva a solicitação de licenças além do necessário. Se todas as empresas solicitarem mais do que desejam de forma uniforme, não há distorção no comércio; porém, se o mais provável acontecer e a solicitação não ocorrer de forma uniforme, a distribuição de licenças é afetada, provocando incerteza e custos de planejamento desnecessários. (Skully, 2001a; Hermann, Kramb, Mönnich, 2000).

Para DeGorter e Sheldon (2001) e Skully (2001a), o fato de a redução proporcional do volume da quota poder resultar em uma quantidade fora do padrão comercial - por exemplo, frações de um contêiner - pode vir a provocar custos desnecessários com transporte. O autor aponta ainda que esse método pode favorecer produtores menos eficientes, ocasionando perdas econômicas e dissipação de renda.

Abbott (2001) e Hermann, Kramb e Mönnich (2000) apontam ainda para a pouca transparência, o caráter discriminatório e a imposição de custos adicionais a exportadores de método licença sobre demanda do sistema de quotas tarifárias. 


\subsection{3 "First come, first served"}

O método de administração de quotas tarifárias denominado first come, first served consiste em permitir importação até que o volume da quota seja preenchido. Uma vez completada a quota, cobra-se a tarifa extraquota.

Nesse método, não há a distribuição de direitos de importação e cabe ao órgão administrador determinar a data ou período de importação intraquota. Em Skully (2001a) a participação do método first come, first served é de $11 \%$ do total de quotas tarifárias registradas na OMC.

DeGorter e Sheldon (2001) afirmam que, embora não haja distribuição de licenças, o importador sofre o risco de encontrar a quota preenchida quando da chegada de seu carregamento à alfândega, tendo assim que arcar, além das despesas corriqueiras, com o pagamento da tarifa extraquota ou de estocagem, ou ainda de envio do produto para outro destino.

Hermann, Kramb e Mönnich (2000) afirmam que nesse método a localização geográfica torna-se um fator de competitividade, especialmente se a commodity for perecível. Dizem ainda que se o produto não for perecível, uma prática comum é a estocagem no porto de destino, de forma que a realização do processo de exportação aguarde a abertura do período de importação intraquota. Nesse caso, incorre-se em custos de estocagem que não ocorreriam se não houvesse a imposição desse método de administração.

Já Abbott (2001), Gervais e Surprenant (2000) e Skully (2001a) apontam que o método first come, first served influencia os importadores a realizarem suas transações no começo da temporada intraquota e estocar o produto para vender na melhor época, para, assim, auferir uma maior renda adicional (rents). 
DeGorter e Sheldon (2001) nesse sentido apontam que o método first come, first served tende a permitir uso ineficiente de recursos devido ao aumento nos custos de estocagem, à discriminação entre os exportadores geograficamente mais distantes, às incompatibilidades do período de safra e ao período de importação intraquota entre os diversos países. Esse método desencoraja qualquer iniciativa de exportação quando não se pode garantir a aplicação da tarifa intraquota. Isso pode explicar os seus níveis reduzidos de preenchimento da quota.

Sob o ponto de vista de um governo protecionista, diz Skully (2001a), há um incentivo de atrasar as notificações de abertura de importações intraquota. O governo pode inibir o preenchimento da quota anunciando seu preenchimento, quando de fato isso não ocorreu. Pode ainda aumentar sua arrecadação divulgando o preenchimento da quota e cobrando tarifa extraquota dos importadores. A falta de transparência, nesse caso, trabalha a favor do governo. Dessa forma, corrobora Bureau (1999), o método first come, first served encoraja a concentração e a sazonalidade das importações.

\subsubsection{Alocação histórica}

O método de administração de quotas tarifárias denominado alocação histórica (historical allocation) consiste na distribuição de direitos de importação intraquota para nações específicas seguindo um critério com base nas importações históricas do país.

Em Skully (2001a) a participação do método de alocação histórica perfaz $5 \%$ do total de quotas tarifárias registradas na OMC.

Hermann, Kramb e Mönnich (2000) e Bureau (1999) atentam para o fato de que novos concorrentes devem primeiramente exportar sujeitos a tarifa extraquota para no futuro ser incluídos no processo de alocação de licenças. Já Skully (2001a) apresenta que a base histórica não é revisada freqüentemente, 
sendo que uma determinada distribuição é mantida por muitos anos, não permitindo variação mesmo que as condições de mercado propiciem isso.

Ressalte-se que o método de administração de alocação histórica foi criado de forma a assentar os privilégios e tratamentos diferenciados concedidos a determinados países, sob a forma de acordos preferenciais, anteriores à Rodada Uruguai (Abbott, 2001).

DeGorter e Sheldon (2001) discutem o fato de a alocação histórica levar a perdas econômicas por favorecer firmas ou países menos eficientes na produção da commodity. Nesse sentido, Abbott (2001) aponta para o caráter discriminatório do método e seu conflito direto com o princípio da nação-maisfavorecida (MFN) do GATT/OMC.

\subsubsection{Leilão}

O método de administração das quotas tarifárias denominado leilão (auctions) consiste em estabelecer um número determinado de licenças e leiloá-las. Abbott (2001) e Skully (2001a) apontam que esse método é o mais eficiente economicamente, pois favorecerá o produtor com menor custo de produção, logo, o mais eficiente. Entretanto, para que funcione bem, o mercado deve ser suficientemente líquido, ou seja, ter a participação de grande número de interessados em adquirir licenças para importação.

Skully (2001a) aponta como 4\% a participação desse método no total de quotas tarifárias registradas na OMC.

Nesse método as regras do jogo são transparentes a todos os participantes, afirmam Hermann, Kramb e Mönnich (2000), uma vez que a quota seria totalmente preenchida por ofertantes mais eficientes, porque estes poderiam arcar com os maiores lances. 
Em DeGorter e Sheldon (2001), o método de leilão gera um retorno maior ao governo, pois este se apropria das rendas adicionais (rents). No entanto, o método de leilão não é muito utilizado e ainda, segundo o artigo, possui uma baixa taxa de preenchimento de quota (quota under-fill). Isso acontece possivelmente porque grupos de compradores adquirem os direitos de importação e adiam parte da importação licenciada na espera de uma pressão de demanda e conseqüente elevação de preço, adquirindo, dessa forma, uma renda adicional (rents) maior.

Um ponto apresentado por Joerin e Lengwiler (2003) é a flexibilidade do método leilão. Esse método adapta-se à quantidade total de quotas de acordo com a necessidade do mercado, desviando renda dos detentores de direitos de importação para o governo, constituindo-se em uma forma nãodiscriminatória de taxação, além de perfeitamente transparente.

\subsubsection{Empresas estatais}

O método de administração de quotas tarifárias denominado empresas estatais (state trading enterprises) consiste em conceder os direitos de importação intraquota, total ou em grande parte, para organizações estatais.

Abbott (2001) aponta que esse método não é muito transparente, podendo tornar-se discriminatório e impor custos extras aos exportadores. DeGorter e Sheldon (2001) corroboram com essa idéia ao afirmar que, devido aos exportadores terem de negociar com uma única entidade, estes devem arcar com custos extras de transação e informação.

DeGorter e Sheldon (2001) ainda dizem que as empresas estatais são mais suscetíveis a pressões políticas, as quais visam à proteção de produtores domésticos da competição internacional, estes produtores, entretanto, não necessariamente conseguem suprir toda demanda do país, o 
que estimula a demanda por importação. Nesse caso, a manutenção de preços elevados devido a imposição das quotas tarifárias gera ineficiência econômica.

Skully (2001a) aponta para a pouca transparência do método, pois cada instituição possui seu próprio método de distribuição das licenças, muitas vezes arbitrários. Abbott (2001) e Hermann, Kramb e Mönnich (2000) confirmam essa afirmação e complementam dizendo que o preenchimento das quotas desse método é freqüentemente melhor utilizado, provavelmente para manter sua forma de gerenciamento.

\subsubsection{Grupos de produtores}

O método de administração das quotas tarifárias denominado grupo de produtores (producer groups), de maneira semelhante à empresa estatal, consiste em conceder, total ou em grande parte, para organizações representativas de produtores domésticos os direitos de importação intraquota (Skully, 2001a).

Para DeGorter e Sheldon (2001), o controle das importações por um grupo de produtores leva a um processo de escolha entre os benefícios de obter renda adicional (rents) e a perda de excedente do produtor devido a uma maior competição internacional. Não preencher a quota é vantajoso se a renda auferida for menor que a perda do excedente do produtor causado pelo aumento da produção. O resultado depende da relação entre as elasticidades da demanda e oferta doméstica para a commodity.

DeGorter e Sheldon (2001) ainda apontam para a possibilidade de os produtores domésticos importarem um produto de qualidade inferior, obedecendo ao acordo de acesso mínimo, mantendo seus rendimentos mediante o prêmio de qualidade oferecido pelos consumidores aos seus produtos. No entanto, isso somente será possível se a elasticidade cruzada entre os produtos nacionais e importados for baixa. Outra opção é destruir os 
produtos importados, o que geraria maiores custos aos produtores, os quais seriam repassados aos consumidores.

\subsubsection{Combinação de métodos e métodos não especificados}

Duas outras opções estão registradas na OMC como possíveis métodos de administração de quotas tarifárias. Uma se refere à combinação de dois ou mais métodos apresentados e outra a métodos ainda não registrados. Como exemplo deste último, temos o sorteio. Esse método já foi utilizado pelos Estados Unidos na distribuição de licenças de importação para leite em pó e manteiga (DeGorter e Sheldon, 2001).

\subsubsection{Condições adicionais}

O sistema de quotas tarifárias estabelece ainda condições adicionais a sua aplicação no esquema multilateral de comércio. Essas condições adicionais visam evitar atitudes oportunistas, favorecer parceiros comerciais, promover a produção doméstica e garantir a procedência de produtos, entre outros.

Podem ser encaradas como barreiras adicionais no propósito de obtenção de maior acesso a mercados, embora estejam calcadas, como veremos adiante, em argumentos sustentados pelo GATT/OMC.

Conforme registradas na Organização Mundial do Comércio, as condições adicionais estabelecem limite de participação de mercado, performance comercial passada, exigência de compra doméstica e certificados de exportação.

\subsubsection{Limite de participação de mercado}

O limite de participação de mercado (limits on tariff quota shares) consiste em especificar o market share máximo para cada importador ou fixar 
uma quantidade máxima para cada importador ou embarque. Segundo Skully (2001 b) e Abbott (2001), essa condição visa impedir que um único importador ou grupo de importadores monopolizem o mercado.

\subsubsection{Performance comercial passada}

A performance comercial passada (past trading performance) mantém a participação no mercado de empresas importadoras tradicionais (uma forma de parceria). Cabe salientar que essa exigência não considera as importações passadas por país, ou seja, não pode ser confundida com o método de alocação histórica.

Skully (2001b) aponta que, se um trader obtém o direito de importação intraquota, mas não conseguir efetuá-la satisfatoriamente, esse direito pode ser realocado para outro trader.

\subsubsection{Exigência de compras domésticas}

A exigência de compras domésticas (domestic purchase requirement) consiste em exigir, em contrapartida à permissão de importação, que o importador efetue compras ou absorva o mesmo produto doméstico, ou seja, vincule a importação a uma compra de produtos de origem doméstica.

Skully (2001b) nos dá um exemplo. Para importar uma tonelada de carne sujeita à tarifa intraquota, um importador deve comprar $X$ toneladas de carne no mercado doméstico.

Essa condição para Abbott (2001) aumenta o custo de importação de algumas empresas que não estariam envolvidas com a produção doméstica.

\subsubsection{Certificados de exportação}

Os certificados de exportação (export certificates) consistem na apresentação de certificados ou licenças do país de origem que garantam a 
idoneidade e procedência do produto. Skully (2001b) diz que os certificados de exportação são geralmente empregados para assegurar que o produto importado é realmente produzido no país exportador. Visa evitar triangulação comercial.

\subsection{Alguns aspectos legais sobre as quotas tarifárias}

Um modelo econômico é uma abstração e simplificação da realidade. Nem sempre é possível isolar os efeitos de mudanças nas condições de mercado daquelas oriundas de modificações legais e institucionais, bem como do ambiente político internacional. No "mundo real", nem sempre o que é proposto como viável ou necessário é possível de ser realizado. Nesse contexto, o presente trabalho pretende mostrar o paralelo entre a aplicação do sistema de quotas tarifárias e os acordos de comércio, no intuito de verificar se a composição legal desses acordos exerce influência sobre o acesso a mercado.

Cabe ressaltar que este trabalho assume como legislação pertinente, especificamente, o GATT/OMC, que regem o comércio internacional de bens, enquanto o AARU volta-se unicamente ao comércio de itens agroindustriais. $O$ enfoque principal será dado às proposições do GATT de defesa da concorrência e do livre comércio, enfatizando os princípios de nãodiscriminação e transparência e do compromisso de acesso mínimo ou corrente assumido no AARU.

\subsubsection{Leis e instituições internacionais de comércio}

Acesso a mercados, métodos de administração, imposição de quadros tarifários, proteção comercial. Todos esses termos estão diretamente relacionados a acordos e compromissos assumidos internacionalmente. Nesse sentido, para estudar o rigor da aplicabilidade desses acordos e compromissos, 
um dos objetivos desse trabalho, uma breve abordagem sobre as leis e instituições de comércio deve ser apresentada.

Inicialmente, o princípio da cooperação internacional na resolução de problemas de caráter econômico, bem como vários outros problemas internacionais, incentivou as Nações Unidas na criação de entidades especializadas para dispor sobre assuntos específicos.

Segundo Accioly e Silva (1996), essas entidades são criadas por acordos intergovernamentais e com amplas responsabilidades internacionais, definidas em seus instrumentos básicos, nos campos econômico, social, cultural, educacional, sanitário entre outros. Com o passar do tempo, essas organizações especializadas vêm adquirindo prestígio internacional, tanto assim que o seu direito de assinar tratados internacionais passou a ser reconhecido pela Convenção de Viena de 1985, que dispõe sobre o direito de tratados de organizações internacionais.

O GATT (Acordo Geral de Tarifas e Comércio) não é uma organização especializada, mas, em virtude de suas relações com outras organizações, foi incluído nesse rol até a criação, em 1994, da OMC (Organização Mundial do Comércio). A OMC é a instituição que goza dos inúmeros privilégios e imunidades das organizações especializadas preconizados pelas Nações Unidas no que tange ao comércio internacional.

Do ponto de vista do comércio internacional, as leis e instituições possuem um importante papel na determinação das condições de competitividade predominante nos mercados domésticos, favorecendo a liberalização comercial e a performance exportadora (Hoekman,1995).

As leis e instituições também possuem importante função contra ações desleais, injustas e/ou oportunistas no tocante à competição internacional, como dumping e subsídios, tendo, assim, ação direta nas 
relações de acesso aos mercados. Nesse sentido, há a defesa de um regime comercial liberal, crucial no fomento de setores domésticos competitivos.

Hoekman (1995) propõe a idéia de que reduzir tarifas e eliminar restrições quantitativas não é suficiente para assegurar que mercados tornemse ou permaneçam competitivos. Outras ações, como as políticas governamentais, características do mercado consumidor, processos e padrões inerentes a cada bem transacionado e a predisposição à abertura de mercados também são muito relevantes, ações que também são reguladas pelo GATT/OMC.

As leis e instituições comerciais, representadas nesse trabalho pelo GATT e pela OMC, constituem a estrutura por meio da qual a política comercial é desenvolvida e implementada. Cabe aos governos, portanto, estabelecerem leis e instituições que considerem os mais diferentes interesses específicos no processo de formação da política comercial.

Nesse sentido, discute Hoekman (1995), as pressões de lobbies podem contagiar a política comercial a ser implementada. Cabe salientar que o nível de proteção comercial não é somente determinado pelas tarifas e restrições quantitativas, que são os efeitos diretos, mas também pelos processos e procedimentos administrativos utilizados na classificação, valoração e processamento dos produtos. Esses são efeitos indiretos de proteção comercial e estabelecidos pela política comercial implementada.

No tocante às políticas comerciais, medidas não-discriminatórias e transparentes são princípios expressamente defendidos pelo GATT/OMC. Já no tocante aos sistemas de quotas tarifárias, esses princípios sofrem, muitas vezes, distorções capazes de causar desvio de comércio, prejudicando economias mais eficientes e descaracterizando os ideais de livre comércio defendidos internacionalmente. 


\subsection{O GATT 1947}

O Acordo Geral sobre Tarifas e Comércio (GATT), formalmente, é um tratado intergovernamental internacional criado para dispor sobre as regras de comércio. Este acordo também exerceu, por cerca de 40 anos, o papel reconhecido de instituição internacional. Em 1995, a OMC assumiu sua estrutura mantendo as decisões, os procedimentos e as práticas aduaneiras originadas de sua criação, em 1947, e aprimorados por constantes revisões em rodadas de negociações multilaterais (Jackson, 1999).

O GATT 1947 teve como objetivo, predominantemente, disciplinar as ações de governo em relação aos instrumentos de política comercial, como as tarifas, os subsídios e as quotas tarifárias. Logo, o GATT, tanto quanto a OMC, pode ser considerado como um regulador de ações governamentais regulatórias que afetam o comércio e as condições de competitividade face à importação de produtos nos diferentes mercados (Hoekman e Kostecki, 2001).

Uma percepção fundamental dos fundadores do GATT em 1947 era a de que uma instituição multilateral facilitaria a cooperação entre os países por meio do aumento da interdependência entre as nações mais do que por interesse econômico, o que ajudaria a reduzir o risco de guerra.

Outra percepção era a de que o crescimento esperado da renda real oriunda da liberalização comercial e do acesso não-discriminatório aos mercados reduziria o escopo de conflitos políticos. E ainda o aumento da transparência e a existência de um fórum para dirimir conflitos comerciais reduziriam a probabilidade desses conflitos serem resolvidos de outras formas, entre elas, a força militar.

Nesse sentido, ressaltam Hoekman e Kostecki (2001), os arranjos mutuamente vantajosos envolvendo uma redução substancial de tarifas e outras barreiras ao comércio, tanto quanto a eliminação do tratamento 
discriminatório no comércio internacional, tornariam possível aumentar o padrão e a qualidade de vida, assegurar o pleno emprego, crescimento da renda real e da demanda efetiva, utilizar plenamente os recursos de cada nação e expandir a produção e o comércio de bens. Ou seja, conseguir todos os objetivos do preâmbulo do GATT 1947.

O GATT 1947 sofreu alterações ao final da Rodada Uruguai, em 1995. Embora muitas de suas obrigações e procedimentos continuem inalterados, partes substantivas foram transferidas para a OMC em 1994. Isso diferencia o GATT 1947 do GATT 1994. O primeiro assumia a função de tratado de comércio e instituição internacional; o segundo é simplesmente um conjunto de regras de comércio, constantes da OMC, esta a instituição internacional que dispõe sobre comércio. Entretanto, mantiveram-se as regras e prerrogativas iniciais que norteiam todo o sistema multilateral de comércio.

Para Hoekman e Kostecki (2001), cinco princípios são de particular importância para entender o GATT anterior a 1994. São eles: nãodiscriminação, reciprocidade, aplicabilidade de compromissos, transparência e válvulas de segurança. Destaque deve ser dado aos princípios de nãodiscriminação e transparência, uma vez que a busca por um comércio transparente e não discriminatório continua a regular as concessões comerciais assistidas pelo acordo, além de esses princípios serem afetados em maior intensidade pelo sistema de quotas tarifárias.

\subsubsection{Princípio da não-discriminação}

O princípio mais importante contido nos acordos da OMC, apontado por vários autores, é o de não-discriminação na forma incondicional da regra da nação-mais-favorecida (NMF), estabelecida no artigo I do GATT 1947.

Essa regra defende que nenhum membro signatário do acordo seja tratado menos favoravelmente que outro membro. Logo, o melhor tratamento 
oferecido a um produto específico de um membro signatário deve ser estendido a todos os demais membros da organização.

Um princípio complementar de não-discriminação, diz Hoekman (1995), Jackson (1997) e Horn e Mavroidis (2000), é a regra de tratamento nacional (NT) estabelecida no artigo III do GATT. Essa regra estabelece que produtos estrangeiros, uma vez que serão consumidos internamente, não devem ter tratamento menos favorável que os produtos domésticos.

A não-discriminação deveria ser exercida por todos os países signatários da OMC, uma vez que são livres para impor tarifas desde que obedeçam a esse critério. Lloyd (2000) afirma que o GATT procura a redução substancial de tarifas e outras barreiras e a eliminação de tratamentos discriminatórios ao comércio internacional. Acredita que o objetivo fundamental do GATT, portanto, seja a promoção de um ambiente competitivo e a jurisdição comercial pode influir nas questões de bem-estar e desvio de comércio.

Sob a perspectiva legal, apontam Horn \& Mavroidis (2000), o GATT/OMC é basicamente um acordo sobre não-discriminação, permitindo significantes isenções sob a forma de acordos preferenciais de comércio e proteções eventuais (contingentes), por exemplo.

Do ponto de vista econômico, segundo Jackson (1999), a nãodiscriminação pode representar um efeito salutar de minimização de distorções de mercado, o que corrobora com muitos argumentos a favor do livre comércio. Esse autor aponta também que a cláusula NMF provoca a generalização de políticas comerciais de liberalização de forma global.

Jackson, Davey e Sykes (1995), citando o Estudo no 9 do corpo executivo do GATT, expressam que: "A racionalidade básica da NMF é que, se todos os países observarem o princípio, todos se beneficiarão no longo prazo 
por meio da utilização mais eficiente dos recursos. Além do mais, se o princípio for observado, haverá menor probabilidade de disputas comerciais".

Esses autores abordam cinco benefícios da não-discriminação, precisamente quanto à aplicação da cláusula da nação-mais-favorecida:

- Primeiro: do ponto de vista econômico, o princípio NMF assegura que cada país conseguirá satisfazer o total de suas necessidades por importação com aquele ofertante que for o mais eficiente, permitindo, assim, a aplicação livre das vantagens comparativas;

- Segundo: do ponto de vista da política comercial, o compromisso NMF protege o valor de concessões bilaterais. Devido ao tratamento NMF, medidas de abertura de mercado podem ser generalizadas como uma força positiva para alcançar mais rapidamente o livre comércio no mundo, de forma que, sem o princípio da nação-mais-favorecida, haveria inevitavelmente discriminação, o que provocaria ainda mais discriminação;

- Terceiro: do ponto de vista da política internacional, a cláusula NMF mobiliza poder de grande economias em favor de seus interesses e pequenas economias por oferecer tratamento igual entre os países. Na prática isso garante o acesso de novos players aos mercados internacionais. Sem favorecimento e concessões de vantagens especiais, há uma redução significativa nas tensões internacionais;

- Quarto: do ponto de vista da política doméstica, o compromisso NMF é aplicado diretamente e de forma transparente; assim, torna-se uma forma simples de controle e administração da proteção comercial;

- Quinto: a cláusula NMF tem significância constitucional, de modo que, se um governo tiver o compromisso NMF assegurado, interesses especiais 
terão menor força para obter concessões discriminatórias, ou seja, diminui o poder dos lobbies.

No entanto Horn e Mavroidis (2000) discutem que a discriminação pode ser desejável do ponto de vista social. Esses autores afirmam que existe dificuldade de construir um argumento geral e robusto a favor da regra da nação-mais-favorecida (NMF). Primeiramente, não há como conhecer o ótimo global sob livre comércio; então, qualquer medida de liberalização envolverá a comparação entre situações de equilíbrios distorcidos, ou seja, não existe como mensurar se a medida de liberalização está realmente elevando o nível de bemestar global. Esse tema é amplamente discutido pela teoria econômica no que se refere à abordagem do second best.

Em segundo lugar, o impacto da utilização da regra da NMF não pode ser avaliado simplesmente se comparando uma estrutura tarifária sujeita à regra e outra não. Horn e Mavroidis (2000) apontam a inviabilidade de tal tentativa empiricamente.

No aspecto histórico, Horn e Mavroidis (2000) dizem que as reduzidas tarifas cobradas sobre produtos industrializados como resultado da regra da nação-mais-favorecida não garantem o mesmo efeito para outros setores da economia.

Bergstein (1996) propõe que, para conseguir o objetivo de livre comércio, deve haver a remoção de todas as barreiras governamentais (tarifárias e não-tarifárias) nas transações entre os países para todos os bens e serviços, ou seja, distorção zero no comércio internacional tanto quanto a remoção de qualquer incentivo governamental, tais como, subsídios e favorecimento aos investimentos estrangeiros na promoção comercial. Dessa forma, elimina-se todo o diferencial de tratamento e inconsistências entre commodities e grupos geográficos. 
Cabe ressaltar a opinião de DeGorter e Sheldon (2001) de que o princípio do GATT de não-discriminação afirma que a participação no comércio seria determinada pela eficiência relativa dos ofertantes e não por métodos discriminatórios alternativos.

No tocante ao tratamento nacional, Hoekman (1995) salienta que este princípio é uma condição necessária para assegurar um mesmo campo de atuação entre firmas estrangeiras e domésticas. No entanto, os governos procuram discriminar firmas estrangeiras para proteger indústrias domésticas.

Do ponto de vista da aplicação do princípio, o GATT/OMC consolidaram tarifas, de forma que nenhum membro pode elevar suas tarifas acima desse valor. Assim, uma mesma tarifa é aplicada de forma geral a todos os membros.

Se a cláusula da nação-mais-favorecida provoca a generalização da liberalização das políticas comerciais, também minimiza os custos de formulação de regras e arbitragens e reduz o custo de transação por não haver necessidade de fiscalização de regras de origem na aplicação de tarifas e outras restrições ao comércio. De uma forma simples, o compromisso NMF "desburocratiza" o comércio.

Cabe ressaltar, como amplamente discutido pela literatura, que a regra NMF do GATT é uma obrigação fundamental e central da política comercial internacional, porém possui problemas de interpretação. A maior dificuldade refere-se ao escopo de cobertura da cláusula NMF, uma vez que o GATT permite uma série de exceções, as quais serão tratadas oportunamente neste trabalho. 


\subsubsection{Transparência}

Como resultado da Rodada Uruguai, ficou acordada a transparência das obrigações e direitos legais, derivados do artigo II: 1(b) do GATT - Relação de Concessões -, de modo que a natureza e nível de qualquer imposto ou obrigação arrecadados sob forma tarifária devem ser registrados e publicados pela OMC.

A regulação e os procedimentos relacionados ao processo de formação de política comercial devem ser definidos por legislação. O papel das leis, segundo Hoekman (1995), é agrupar as regras dos "jogos da política comercial". Processos básicos relacionados a um grupo de tarifas de produtos específicos e outras proteções, bem como os processos de administração, seriam definidos em lei. Isso asseguraria maior estabilidade e, portanto, menor incerteza aos traders. Hoekman e Kostecki (2001) complementam essa idéia afirmando que transparência, tanto no nível multilateral quanto em nível nacional, é essencial para reduzir as incertezas e fazer valer os acordos.

Cabe ressaltar que as leis podem ser alteradas. Assim, o debate entre as partes afetadas e favorecidas na tentativa de persuadir o resultado das deliberações fomenta um quadro transparente de tomada de decisão.

Se, ao contrário, as regras não forem legisladas por um conjunto de decretos governamentais, haverá possivelmente menor transparência, maior incerteza e mais possibilidades para atividades oportunistas.

A OMC vem-se esforçando no fomento de políticas comerciais transparentes pela publicação de estudos, relatórios, estatísticas, documentos e notícias por meio de sua secretaria, apoiada sob o artigo $X$ do GATT, que exige que todas as leis, regulamentos, decisões judiciais e regras administrativas relevantes sejam publicadas e tornadas públicas. 
Hoekman, Mattoo e English (2002) destacam que a transparência é um dos pilares básicos da OMC e sua obrigatoriedade legal é estabelecida no artigo $X$ do GATT e no artigo III do GATS. Esses artigos sugerem que os membros da OMC devem publicar suas regras e determinações comerciais, estabelecer e manter instituições para revisão contínua das suas decisões administrativas que afetem o comércio internacional, responder a questionamentos e solicitações de informações efetuadas por outros membros, e notificar alterações nas políticas comerciais para a OMC.

A exigência de transparência, suplementar à supervisão das políticas comerciais dos países-membros, facilitou a preparação de relatórios específicos por país e a discussão do Conselho-Geral da OMC, e a supervisão efetuada tanto por cidadãos dos países-membros quanto por parceiros comerciais acaba por reduzir a possibilidade de as nações burlarem suas obrigações. Dessa forma é que se reduz a incerteza referente à manutenção da postura política.

\subsection{O GATT 94}

O GATT, ao final da Rodada Uruguai, sofreu algumas alterações essenciais para sua modernização e atualização à nova realidade mundial. Uma de suas mudanças, segundo Hoekman e Kostecki (2001), foi a tentativa de aproximação das regras adotadas pelo setor agrícola daquelas adotadas pelo setor industrial. Os autores afirmam que as regras adotadas pelo GATT 1947 para o comércio agrícola eram notadamente mais fracas do que as adotadas para produtos manufaturados.

Desta (2002) afirma que a posição da agricultura no sistema multilateral de comércio é rica em paradoxos. Enquanto o sistema é capaz de ostentar um alto nível de liberalização bem-sucedida para produtos industriais, a agricultura tem-se mantido, quando não regredido, seus níveis de proteção ao comércio. 
Até o final da Rodada Uruguai, para Hoekman e Kostecki (2001), duas grandes diferenças eram verificadas entre as regras de comércio agrícola e industrial. A primeira era a permissão de manter quotas de importação para produtos agrícolas, e a segunda é a possibilidade de os governos oferecerem subsídios à exportação para produtos primários ou outros produtos essenciais. Essas diferenças, entre outras, passaram a ser reguladas pelo Acordo sobre Agricultura da Rodada Uruguai (AARU), um grande passo para a liberalização comercial da agricultura conquistado ao final dessa rodada de negociações multilaterais.

Em 1994, instalou-se a OMC, que incorporou o GATT 1947 e suas alterações e inovações, entre as quais o AARU e ambiciosas prerrogativas quanto à concessão de acesso a mercado ${ }^{15}$ para produtos agrícolas.

\subsubsection{Acesso aos mercados no AARU e GATT 1994}

O Acordo sobre Agricultura da Rodada Uruguai (AARU) foi constituído sobre três pilares: apoio interno, incentivo à exportação e acesso a mercado.

Como uma medida de melhoria do acesso a mercado, durante a Rodada Uruguai, os membros signatários do GATT instituíram a tarificação, ou seja, conversão de barreiras não-tarifárias em tarifárias.

\footnotetext{
${ }^{15}$ Acesso a mercado está relacionado aos instrumentos e disciplinas que afetam a entrada de produtos de um país em outros países, decorrente da imposição de restrições e limitações à importação (tarifas, quotas tarifárias, quotas de importação, etc.), com influência direta na competitividade entre produtos importados e seus similares domésticos. http://www.iconebrasil.org.br/index_glossario_1.asp?idpalavra=19
} 
Cabe ressaltar que essa medida, conforme Hoekman e Kostecki (2001), considera que tarifas aduaneiras são em princípio o único instrumento de proteção comercial permitido pelo GATT e preferíveis a qualquer outra medida protecionista. Essa preferência deve-se a sua consistência com a teoria econômica, devido a sua capacidade de:

a) manter uma ligação entre os preços domésticos e o internacional, assegurando que o ofertante mais eficiente consiga abastecer o mercado;

b) constituir-se na forma mais fácil de assegurar a não-discriminação (alocação de quotas de alguma maneira se baseiam em decisões arbitrárias);

c) transparência;

d) facilitar os cálculos de proteção real;

e) gerar renda para o governo.

Outro importante resultado promovido pela Rodada Uruguai foi a instituição de um nível mínimo de importação garantida pelos membros signatários àqueles produtos anteriormente protegidos por barreiras nãotarifárias.

Acompanhados pela fixação de várias quotas tarifárias, no bojo do processo de tarificação e de importação mínima garantida, todos os membros signatários assumiram o compromisso de permitir acesso mínimo ou corrente a todos os produtos agroindustriais. Cabe ressaltar um problema: em muitos casos, aponta Desta (2002), o volume de importação sob acesso mínimo dadas as modalidades de seu cálculo era ínfimo, quando não inexistente. 
O compromisso de acesso mínimo consiste em garantir um mínimo de importação no valor de $3 \%$ de seu consumo doméstico, tendo como período base os anos de 1986 a 1988. Foi também acordada a elevação do valor de acesso mínimo para 5\% até o ano 2000, e 2004 para países em desenvolvimento.

Já o compromisso de acesso corrente é empregado para aqueles produtos em cujo período-base as importações excediam o valor de $3 \%$ do consumo doméstico. Nesse caso, o país fica impedido de reduzir a proporção do acesso ao mercado perante seu consumo doméstico.

Cabe ressaltar que os países desenvolvidos comprometeram-se em reduzir todas as tarifas, com base no mesmo período, em média de $36 \%$, com redução mínima de 15\% para cada linha tarifária específica. Países em desenvolvimento concordaram em promover a mesma ação, entretanto, com redução média de $24 \%$ e redução mínima de $10 \%$ para cada linha tarifária específica.

Segundo DeGorter e Sheldon (2001), o artigo IV do AARU estabelece as disciplinas para acesso a mercados. O parágrafo 2 desse artigo destaca que: "members shall not maintain, resort to, or revert to any measures of kind which have been required to be converted into ordinary customs duties". Essas medidas incluem restrições quantitativas à importação, cobranças variáveis sobre importações, preços mínimos de importação, licenciamento discriminatório de importação e medidas não-tarifárias, entre outras.

O artigo XI do GATT 1947, mantido pelo GATT 1994, proíbe restrições quantitativas, estabelecendo: 
"No prohibitions or restrictions other than duties, taxes or other charges, whether made effective through quotas, import or export licenses or other measures, shall be instituted or maintained by any contracting party on the importation of any product of the territory of any other contracting party or on the exportation or sale export of any product destined for the territory of any other contracting party" (The General Agreement on Tariff and Trade - GATT, 1947, p.13).

Nesse sentido, a harmonização e simplificação dos sistemas e procedimentos de distribuição de direitos de importação podem vir a reduzir os efeitos das restrições comerciais, aponta Hoekman (1995), o que corresponde à transparência incentivada pela OMC.

O artigo XI do GATT 1994 estabelece a eliminação geral das restrições quantitativas. Existe, entretanto, um grande número de exceções que podem ser utilizadas sob base não-discriminatórias.

O artigo XIII do GATT 1994, que discorre sobre a administração de restrições quantitativas de forma não-discriminatória, governa a administração de restrições quantitativas incluindo as quotas tarifárias. Esse artigo pode ser interpretado, segundo DeGorter e Sheldon (2001), como sendo inerentemente contraditório. Defende por um lado a não-discriminação e a utilização de tarifas em vez de restrições quantitativas, mas também permite métodos discriminatórios na alocação de direitos de importação do sistema de quotas tarifárias.

$\mathrm{Na}$ rodada de negociações multilaterais anterior à Rodada Uruguai, a Rodada Tóquio, foi estabelecido um Acordo sobre Processos de Licenciamento das Importações com a proposta básica de estabelecer programas de 
distribuição de direitos de importação (quotas) de forma neutra e administração justa. Em seu artigo I, há a exigência que regras relevantes e suas alterações sejam publicadas de imediato. Estabelece ainda, no corpo do documento, que os membros devem assegurar a participação de novos players, principalmente países em desenvolvimento.

Esse acordo foi criado visando que o licenciamento não viesse a se tornar uma forma de barreira comercial. Para tanto, também foi criado um comitê sobre licenciamento das importações na OMC, que tem por finalidade "considerar a adequada disciplina necessária para prevenir distorções comerciais causadas pela operacionalização de licenciamento de importações". E ainda "a efetividade do acordo depende de seus continuados esforços para manter e aumentar a transparência" (Jackson, Davey e Sykes, 1995).

No tocante ao artigo XIII do GATT, a OMC não prevê atitudes oportunistas na obtenção de rendas adicionais (rents) - ganhos obtidos da compra no mercado mundial e venda no mercado doméstico a preço mais elevado - principal fonte de conflitos comerciais e origem de muitas disputas relacionadas às quotas tarifárias. Essa organização regulamenta somente o acesso aos mercados.

A instituição das quotas tarifárias, se de um lado oferece maior acesso a mercado - pelo menos na retórica - quando comparada à situação anterior a Rodada Uruguai, de outro lado, incentiva o controle e ação governamental que estão sempre sujeitos as pressões políticas e sociais domésticas. Citando Desta (2002), 
"The current and minimum access requirements included in the Uruguay Round arrangement for agriculture have their own positive and negative sides. The fact that they attempted to guarantee a certain level of market access regardless of the level of import tariffs resulting from the tariffication process is one of the notable positive aspects of the resulting system. At the same time, the introduction of these minimum levels has necessitated the institution of tariff rate quotas demanding deeper government involvement in trade in the form of licensing regimes and the like, which stands on the negative end of the scale" (Desta, 2002, p.78).

\subsection{Exceções ao princípio de não-discriminação}

O princípio da não-discriminação pode ser considerado, segundo Schwartz e Sykes (1996), a pedra fundamental do GATT, no entanto existem importantes exceções a sua adoção geral. O GATT 1994, em seus artigos XIX e XXIV, permite a proteção de indústrias declinantes e a possibilidade de criação de acordos preferenciais de comércio, uniões aduaneiras e áreas de livre comércio, respectivamente. $\mathrm{O}$ artigo I, $\S 2$, estabelece que acordos preferenciais constituem a exceção permitida mais significativa a regra NMF, sendo, na prática, utilizado principalmente na consolidação de acordos, como o Acordo Geral de Preferências, que países desenvolvidos concedem, em geral, às suas ex-colônias (Jackson, Davey e Sykes, 1995).

Em determinados casos, como problemas de balanço de pagamentos e segurança nacional, o GATT possui instrumentos que podem ser utilizados, visando à defesa justificada de interesses nacionais com atitudes discriminatórias. 
No que tange às quotas tarifárias, a sua utilização tem por objetivo a proteção de commodities de alta sensibilidade política. Ou, em outras palavras, as quotas tarifárias são impostas sobre commodities as quais o país importador não é internacionalmente competitivo, o que sugere a utilização do artigo XIX para proteção efetiva e o emprego do instrumental como barreira.

Outro fator de influência quanto à discriminação no sistema de quotas tarifárias são os acordos preferenciais. Esses acordos são, muitas vezes, utilizados nos processos de distribuição das licenças de importação, como ponto de favorecimento a determinados grupos de países, logo, um critério discriminatório, além desses acordos serem, stricto sensu, discriminatórios por natureza.

Uniões aduaneiras $\mathrm{e}$ áreas de livre comércio propiciam a discriminação de um grupo de países em relação ao resto do mundo. A negociação dos termos desses acordos, dado o contexto atual, passa pela discussão de acesso a mercado de produtos politicamente sensíveis, ou seja, particularmente neste trabalho, pela discussão do sistema de quotas tarifárias.

\subsubsection{Acordos preferenciais}

A ocorrência de acordos preferenciais entre países precedia a existência do GATT. Anteriormente à Segunda Guerra Mundial, várias nações possuíam acordos de acesso preferencial a outros mercados. Muitas colônias e ex-colônias mantinham também regimes especiais de comércio com países europeus a que estavam submetidas. Assim, permitiu-se a manutenção desses regimes, como, por exemplo, o Commonwealth Britânico (Maciente, 2000).

A instituição de sistemas preferenciais, como o Sistema Geral de Preferências (SGP), possibilitou que países em desenvolvimento obtivessem acesso preferencial aos mercados de nações industrializadas, com tarifas reduzidas em relação à tarifa consolidada na OMC, de aplicação geral. 
Para Schwartz \& Sykes (1996), acordos comerciais preferenciais podem possuir algum senso político como uma alternativa quando a maximização global não pode ser atingida - uma alternativa second best. Portanto, essa alternativa dissipa o excedente político por meio da distorção de comércio, o que acaba influindo na estabilidade das concessões comerciais. Ou seja, acordos preferenciais criam externalidades - perda de excedente para os produtores excluídos e distorção de comércio. Bagwell e Staiger (2001) complementam a idéia afirmando que acordos preferenciais somente serão eficientes se permitirem a integração total na forma de uma união aduaneira, logo, um acordo amplo e de aspecto regional.

Tarifas discriminatórias que beneficiam aqueles produtores menos eficientes com tarifas reduzidas propiciam a sua competição com aqueles produtores mais eficientes sujeitos a tarifas elevadas. Esse fenômeno é conhecido como "desvio de comércio" e gera perda de bem-estar. Desvio de comércio não ocorre quando todos os ofertantes estão sujeitos a uma mesma tarifa.

Tarifas não-discriminatórias aumentam o bem-estar global, o que assegura a importação daqueles ofertantes mais eficientes. Essa característica, de acordo com Schwartz e Sykes (1996), permite que qualquer redução tarifária, discriminatória ou não, substitua produtores domésticos menos eficientes por produtores estrangeiros mais eficientes, poupando, assim, recursos de produção e reduzindo os preços aos consumidores, ou seja, o dispêndio anteriormente gasto com o produto menos eficiente passa a ser direcionado para o comércio de outros produtos, criando comércio.Ressalte-se que muitos dos compromissos de acesso mínimo e corrente estão expressos sob forma de quotas para países específicos, ou seja, inconsistentes com o princípio NMF, e violam os princípios do GATT, precisamente em seu artigo XIII, que dispõe sobre a administração de tarifas e quotas (Desta, 2002). 


\subsubsection{Acordos regionais}

Acordos regionais podem ser entendidos como o estabelecimento de acordos preferenciais de liberalização de fluxos comerciais entre um conjunto determinado de países. Essa liberalização, conceitualmente, pode ser total ou limitar-se a uma redução parcial das tarifas e outras barreiras incidentes sobre determinados produtos e pode abranger um conjunto amplo ou limitado de bens e serviços (Maciente, 2000).

Embora o sistema multilateral de comércio pregue a extinção de barreiras comerciais e, portanto, a extinção preferências discriminatórias, o GATT deixou um canal aberto para acordos regionais, especificamente no disposto em seu artigo XXIV. Esse artigo permite que seus signatários estabeleçam áreas de livre comércio ou uniões aduaneiras entre si, desde que essas uniões abranjam parte substancial do comércio entre eles.

Nesse sentido, apontam Schwartz e Sykes (1996) e Hoekman (1995), a integração regional deve seguir as seguintes condições: níveis tarifários e outros tipos de restrições comerciais não devem exceder os níveis anteriores ao acordo, tanto globalmente quanto para cada país participante; e o período de transição entre a assinatura do acordo e sua efetivação completa não deve ultrapassar um período de tempo razoável.

O artigo XXIV do GATT mostrou-se inconsistente quanto aos seus objetivos. Maciente (2000) e Hoekman (1995) dizem que, embora os acordos regionais tenham sido tolerados por razões políticas, a definição imprecisa sobre o que significaria a liberação de parte substancial do comércio nos marcos de um acordo de livre comércio possibilitou a multiplicação de preferências de caráter parcial entre os países, o que divergia da racionalidade inicial do multilateralismo e dos princípios de não-discriminação. 
Na Rodada Uruguai, aponta Hoekman (1995), ficou acordado que os blocos regionais deveriam facilitar o comércio entre seus membros e não elevar as barreiras ao comércio contra países não-membros do bloco pactuante, e sua criação ou ampliação deveriam considerar e evitar os efeitos adversos sobre o comércio entre seus membros.

\subsection{Princípios do GATT, acesso aos mercados e quotas tarifárias}

Dos acordos firmados na Rodada Uruguai, ficou estabelecido, no intuito de demonstrar transparência, que todas as quotas tarifárias seriam registradas na OMC, apontando os quadros tarifários e os respectivos métodos de administração. Skully (2001a) mostra que aproximadamente metade das quotas tarifárias não é utilizada de fato, estas quotas tarifárias adotam o método da tarifa aplicada para somente impor a tarifa intraquota.

O mesmo autor discute os critérios de avaliação dos métodos de administração das quotas tarifárias sugeridos pelo GATT 1994 por meio do seu artigo XIII, que dispõe sobre a administração das restrições quantitativas de forma não-discriminatória. Os critérios apontados são o preenchimento da quota (quota fill) e a distribuição de comércio.

A primeira forma de avaliação requer que as importações intraquota ocorram dentro das condições permitidas pelo mercado, ou seja, os administradores das quotas tarifárias não colocarão nenhum impedimento ao comércio senão o pagamento da tarifa intraquota até que o volume de acesso estipulado seja completado.

Uma vez que esse volume não seja completado, verificam-se as condições de mercado. Se existiu expansão da oferta doméstica ou a redução do excesso de demanda por um produto, o não-preenchimento da quota ocorreu por razões legítimas - não houve demanda doméstica suficiente sob as condições correntes de mercado. 
No entanto, se o não-preenchimento da quota estiver acompanhado de preço doméstico superior ao preço mundial acrescido da tarifa intraquota, por dedução de Skully (2001a), ocorre uma atitude oportunista por parte dos detentores dos direitos de importação. Nesse contexto, países afetados podem requerer explicações.

Skully (2001a) acrescenta que os governos escolhem um método de administração para cada commodity. Logo, as taxas de preenchimento das quotas refletem os fatores determinados pela escolha do governo, ou seja, das propriedades intrínsecas do método escolhido e das condições de mercado do período observado. Esses fatores dificultam a separação e a identificação das suas causas e dos seus efeitos.

As commodities mais sensíveis politicamente têm grande probabilidade de serem administradas por métodos discricionários, como empresas estatais e grupos de produtores (DeGorter e Sheldon, 2001). A Rodada Uruguai e seu acordo de mínimo acesso representaram para muitos países um sério desafio para seus produtores domésticos. Em quase todos os casos, os preços domésticos excediam muito o preço mundial, sendo óbvio o completo preenchimento das quotas. Alguns governos delegaram a autoridade das importações intraquota, em parte ou no todo, às indústrias domésticas, dando alguma compensação a elas na forma de rents. Por essa razão, diz Skully (2001a), as quotas tarifárias administradas por meio de empresas estatais ou grupos de produtores têm elevado nível de preenchimento.

Já os produtos que não são politicamente sensíveis são geralmente administrados de uma forma mais liberal, não exigindo a cobrança das tarifas extraquota, ou seja, utilizando o método da tarifa aplicada.

No que se refere à distribuição de comércio, o artigo XIII, parágrafo 2, do GATT estabelece que: "In applying import restrictions to any product, contracting parties shall aim at a distribution of trade in such product 
approaching as closely as possible the shares which the various contracting parties might be expected to obtain in absence of such restrictions...". Ou seja, as partes devem tentar determinar a efetiva restrição ao comércio sob base tarifária. O princípio econômico que rege o critério de distribuição de comércio é a minimização de distorções de comércio.

O princípio do GATT de não-discriminação assegura que a participação no comércio seria determinada pela eficiência relativa e não por métodos discriminatórios alternativos. O maior problema do desvio de comércio está no favorecimento de ofertantes menos eficientes (aqueles que possuem custos elevados), o que prejudica os consumidores quanto ao nível de bemestar.

A perda de bem-estar pode representar o quanto a restrição está distorcendo o comércio. Nesse sentido, aponta Skully (2001a), o leilão é a forma de administração das quotas tarifárias que promove o máximo de excedente possível mediante a alocação de mercado.

Quanto ao método first come-first served, Skully (2001a) estabelece a hipótese de perfeita correlação entre o custo dos ofertantes e o seu lugar na fila para preenchimento da quota. Esse autor verifica ser essa uma hipótese forte, no entanto, capaz de determinar que quanto menor a correlação entre o custo de produção, ou seja, ofertantes com menor custo de produção serem capazes de preencher primeiramente a quota, maior a expectativa de distorção de comércio. Nesse sentido, o leilão é equivalente ao first come-first served com perfeita correlação entre baixo custo e lugar na fila.

Skully (2001a) propõe ainda que o método licenças sobre demanda é equivalente a um processo First come-first served aleatório, com correlação zero entre custos e lugar na fila de chegada. 
O GATT 1994 estabelece ainda, no seu artigo XIII: 2 (c) e (d), que as quotas podem ser alocadas para países específicos em vez de importadores domésticos e podem considerar um período representativo de tempo para dividir seu mercado, permitindo, portanto, a alocação histórica. No entanto faz uma ressalva: essa distribuição com base histórica das licenças de importação deveria ser a mais próxima possível daquela posição de livre comércio.

Se isso não ocorrer, e não for permitida a venda desses direitos, o sistema favoreceria aqueles países menos eficientes, impedindo o comércio de outros países com menor custo de produção, o que demonstra o caráter discriminatório desse método.

\subsection{Impressões sobre as quotas tarifárias}

A adoção do sistema de quotas tarifárias foi claramente uma tentativa bem-sucedida de manutenção do protecionismo sobre determinados produtos considerados sensíveis, na última rodada de negociações multilaterais do GATT.

A grande retórica para a adoção desse sistema é a de que quotas tarifárias são menos restritivas que um sistema puro de quota de importação, por não limitar a quantidade a ser importada, uma vez que sempre existe a possibilidade de importação pagando-se a tarifa extraquota.

As quotas tarifárias como instrumento limitador de importação são bem estruturadas teoricamente, atingem seus objetivos com primazia. A adoção das quotas tarifárias está diretamente ligada ao assentamento de aspectos políticos, legais e econômicos, dentro de um único ambiente multilateral, precisamente, no GATT 1994 em seu AARU. Percebe-se um certo "malabarismo" jurídico para tornar o sistema incontestável, de forma que, uma vez aceito e ratificado, deve ser cumprido. 
O fato de haver um processo de distribuição de licenças de importação, de forma muitas vezes discricionária e arbitrária, além de um esforço em não tornar o processo claro e previsível e uma série de artigos e parágrafos que moldam os acordos a fim de permitir o uso das quotas tarifárias, é que conduz a idéia de forte pressão à manutenção desse instrumento.

Cabe destacar que essa constatação confronta-se diretamente com o artigo I do GATT, que dispõe sobre não-discriminação, e com o artigo II do GATT, que dispõe sobre transparência.

Neste capítulo foi visto que a adoção do sistema favorece a arrecadação do governo, os produtores domésticos e, principalmente, o importador - detentor do direito de importação.

Também foi estudado que as quotas tarifárias e seus processos de distribuição de direitos da importação arbitrários podem favorecer países produtores menos eficientes. Nesse caso, percebe-se o engajamento dessas nações na manutenção das quotas tarifárias e o apoio àquelas que garantem acesso a seus mercados por meio da aplicação desse sistema. Ou seja, claro embate contra a concorrência e o livre comércio.

Nota-se ainda que a adoção do sistema de quotas tarifárias protege os produtores domésticos da concorrência de produtores mais eficientes no mundo. Estes produtores domésticos agem politicamente para a manutenção do sistema, temerosos com a competição internacional. Outro grupo que defende a manutenção do sistema são os importadores, que garantem rendas adicionais (rents) ao comprarem no mercado mundial e venderem no mercado doméstico a um preço mais alto.

Há muito interesse em jogo. Conforme já dito neste texto, as quotas tarifárias são impostas em apenas $6 \%$ de todas as linhas tarifárias do agronegócio, porcentagem pequena para tamanha importância e dificuldade de 
alteração de regras e dispositivos e tamanha força política para a manutenção do sistema. Isso permite afirmar que a dificuldade de conseguir qualquer liberalização no comércio de bens que são afetados pelo sistema de quotas tarifárias nas negociações em que o Brasil está atualmente envolvido será muito grande. 


\section{AS QUOTAS TARIFÁRIAS E A EXPORTAÇÃO AGROINDUSTRIAL BRASILEIRA}

O Brasil, conforme apontado anteriormente, impõe duas quotas tarifárias que nunca foram, de fato, utilizadas. Por outro lado, as exportações brasileiras do agronegócio são afetadas, em algum grau, por esse sistema de proteção, o que determina uma questão central para o presente trabalho: como as quotas tarifárias afetam as exportações agroindustriais brasileiras?

Um retrato sobre o nível de preenchimento das quotas tarifárias será apresentado neste capítulo, utilizando informações oficiais da OMC, mais precisamente, documentos de sua Secretaria (WTO Secretariat) para o ano de 2001. Esses documentos trazem as informações oficiais mais recentes disponíveis.

Não serão levantadas questões sobre os níveis tarifários, tanto intraquota quanto extraquota, por tratar-se de uma análise inviável do ponto de vista agregado. Isso se deve ao fato de as quotas tarifárias compreenderem muitas linhas tarifárias. DeGorter e Sheldon (2001) exemplificam esse caso para o ano de 1999. Segundo os autores, o Canadá registrou 21 quotas tarifárias que compreendiam 256 linhas tarifárias a oito dígitos do sistema harmonizado. Essas linhas tarifárias possuem ainda componentes ad valorem, específicos e mistos e expressões como "não menos que" e "não maior que". Tarifas mistas e específicas, comumente utilizadas em países desenvolvidos, dificultam ainda mais uma análise pormenorizada sobre a proteção tarifária e, por conseqüência, sobre as quotas tarifárias. 
Nesse sentido, um único resumo estatístico das notificações e outras informações oficiais para avaliar os impactos da adoção das quotas tarifárias não seria capaz de percorrer completamente todo o escopo compreendido pelo sistema, o que somente pode ser verificado por meio de estudos de caso e análises pontuais por produto e por país. Essas formas de análise serão realizadas oportunamente neste trabalho, com um universo restrito aos produtos de maior interesse para o Brasil.

Embora uma análise em âmbito mundial omita muitas informações relevantes somente verificadas caso a caso, sua realização é importante para ilustrar, como uma indicação geral, a forma de operacionalização do sistema. Assim, a próxima seção deste capítulo irá discutir a utilização das quotas tarifárias no mundo.

\subsection{A utilização das quotas tarifárias no mundo}

Conforme já foi explicitado no capítulo anterior, as quotas tarifárias resultaram do AARU. No início de sua adoção, em 1995, foram registradas 1.259 quotas tarifárias em 37 países. Em 2001, última informação oficial agrupada disponível, foram registradas 1.425 quotas tarifárias impostas por 43 países, o que representa cerca de $6 \%$ de todas as linhas tarifárias das commodities agrícolas.

A tabela 2 mostra o número de quotas tarifárias registradas oficialmente na OMC para o ano de 2001. Nela, pode-se verificar que 29 países entre americanos e europeus respondem por $80,6 \%$ de todas as quotas tarifárias. Destaque seja dado à Noruega, Islândia e Polônia na Europa, por registrarem 232, 90 e 109 quotas tarifárias respectivamente. Na América, destacam-se Colômbia, Venezuela e Estados Unidos, com 67, 61 e 54 quotas tarifárias registradas respectivamente. 
Tabela 2. Número de quotas tarifárias por país membro da OMC.

\begin{tabular}{lclc}
\hline País Membro & $\begin{array}{c}\text { № Quotas } \\
\text { Tarifárias }\end{array}$ & País Membro & $\begin{array}{c}\text { № Quotas } \\
\text { Tarifárias }\end{array}$ \\
\hline 1. África do Sul & 53 & 23. Japão & 20 \\
2. Austrália & 2 & 24. Letônia & 4 \\
3. Barbados & 36 & 25. Lituânia & 4 \\
4. Brasil & 2 & 26. Malásia & 19 \\
5. Bulgária & 73 & 27. Marrocos & 16 \\
6. Canadá & 21 & 28. México & 11 \\
7. Chile & 1 & 29. Nicarágua & 9 \\
8. China & 10 & 30. Noruega & 232 \\
9. Colômbia & 67 & 31. Nova Zelândia & 3 \\
10. Coréia do Sul & 67 & 32. Panamá & 19 \\
11. Costa Rica & 27 & 33. Polônia & 109 \\
12. Croácia & 9 & 34. Rep. Dominicana & 8 \\
13. Equador & 14 & 35. Rep. Eslovaca & 24 \\
14. El Salvador & 11 & 36. Rep. Checa & 24 \\
15. Eslovênia & 20 & 37. Romênia & 12 \\
16. Estados Unidos & 54 & 38. Suíça & 28 \\
17. Filipinas & 14 & 39. Tailândia & 23 \\
18. Guatemala & 22 & 40. Taiwan & 22 \\
19. Hungria & 70 & 41. Tunísia & 13 \\
20. Indonésia & 2 & 42. União Européia & 87 \\
21. Islândia & 90 & 43. Venezuela & 61 \\
22. Israel & 12 & TOTAL (43 países) & 1.425 \\
\hline Fonte & & &
\end{tabular}

Fonte: dados de pesquisa e OMC (2002)

Verifica-se ainda a grande presença dos países que fazem parte do Grupo de Cairns, compostos por grande produtores agrícolas, a saber: Austrália, Brasil, Canadá, Chile, Colômbia, Filipinas, Hungria, Indonésia, 
Malásia, Nova Zelândia e Tailândia, que, reunidos, perfazem cerca de 15,7\% de todas as quotas tarifárias registradas em 2001.

Alguns países que utilizam quotas tarifárias, apontados na tabela 2 , nem sempre cumprem os compromissos assumidos na OMC de notificarem anualmente informações completas sobre seu sistema. Conforme anteriormente verificadas por Abbott (2001) e DeGorter e Sheldon (2001), várias notificações não se apresentam uniformemente entre os países. Em muitos casos, há informações desencontradas e discrepantes, "camuflagem" de dados, de forma que não existem informações agrupadas e consolidadas recentes, completas e confiáveis sobre a aplicação das quotas tarifárias no mundo, o que acaba dificultando a análise e retrata bem o problema discutido da transparência no uso do sistema de quotas tarifárias.

Esse tipo de problema pode ser verificado com as informações da tabela 3, na qual, para as 1.425 quotas tarifárias registradas, existem oficialmente 1.377 informações sobre os métodos de administração. Isso se deve, em alguns casos, à recente participação no esquema multilateral de comércio de algumas nações, como a China e países do Leste Europeu, que, por causa disso, não possuem ainda informação passada, e, portanto, sem as eventuais estatísticas sobre quotas tarifárias. Em outros casos ainda, conforme apontam DeGorter e Sheldon (2001), há a falta de revisão constante do sistema em alguns países, principalmente em economias menores, como é o caso de algumas nações da América Latina. 
Tabela 3. Distribuição das quotas tarifárias pelos principais métodos de administração, período 1995-2001.

\begin{tabular}{|c|c|c|c|c|c|c|c|c|}
\hline Método de Administração & 1995 & 1996 & 1997 & 1998 & 1999 & 2000 & 2001 & $\begin{array}{c}\text { Participação } \\
\text { Média (\%) }\end{array}$ \\
\hline 1. Tarifa Aplicada (TA) & 654 & 642 & 673 & 665 & 656 & 639 & 631 & 48,6 \\
\hline 2. Licenças sobre Demanda (LD) & 290 & 299 & 302 & 298 & 310 & 297 & 324 & 22,6 \\
\hline 3. First-Come, First-Served (FC) & 101 & 103 & 147 & 147 & 146 & 153 & 153 & 10,1 \\
\hline 4. Alocação Histórica (HI) & 68 & 82 & 88 & 97 & 97 & 119 & 100 & 6,9 \\
\hline 5. Leilão (LE) & 41 & 39 & 59 & 59 & 59 & 52 & 52 & 3,8 \\
\hline 6. Empresas Estatais (EE) & 22 & 22 & 20 & 19 & 20 & 20 & 21 & 1,5 \\
\hline 7. Grupos de produtores (GP) & 8 & 8 & 7 & 7 & 7 & 9 & 8 & 0,6 \\
\hline 8. Outros (OU) & 12 & 13 & 7 & 7 & 7 & 9 & 8 & 0,7 \\
\hline 9. Mix de Métodos (MX) & 54 & 55 & 58 & 59 & 60 & 60 & 60 & 4,3 \\
\hline 10. Não Especificado (NS) & 9 & 10 & 6 & 6 & 14 & 7 & 20 & 0,8 \\
\hline Total Disponível & 1.259 & 1.273 & 1.367 & 1.364 & 1.376 & 1.365 & 1.377 & 100,0 \\
\hline
\end{tabular}

Fonte: dados de pesquisa e OMC (2002)

A tabela 3 apresenta a distribuição das quotas tarifárias registradas segundo o método de administração utilizado. Pode-se verificar certa constância temporal no uso dos métodos de administração. O método tarifa aplicada permanece no decorrer dos anos como o de emprego mais comum em média, é adotado em $48,6 \%$ das quotas tarifárias registradas. É seguido pelo método licença sobre demanda, que tem participação média em torno de 22,5\% entre 1995 e 2001.

O terceiro método mais utilizado é o first come-first served, que possui participação média de cerca de 10,1\%, acompanhado com uma certa distância pelos métodos mais discriminatórios e politicamente sensíveis (Skully, 2001b), alocação histórica com participação em torno de 7\%, agências estatais com 1,5\%, grupo de produtores com 0,5\% e mix de métodos com participação próxima a 4\%. Ressalta-se a baixa participação do método leilão, com cerca de 3,5\%, participação reduzida para o método que provoca a menor distorção ao comércio, conforme apresentado anteriormente, na revisão de literatura deste trabalho. 
A tabela 3 conduz à 4, a qual mostra o nível de preenchimento por método de administração. As estatísticas na tabela 4 referem-se ao valor médio do preenchimento de todas as quotas tarifárias adotadas na OMC, desde a implantação do sistema em 1995, e foram calculadas a partir das informações disponíveis na OMC, precisamente em sua Secretaria e de suas notificações registradas. Para o seu cálculo, extraiu-se a média simples do valor porcentual do preenchimento médio de cada quota tarifária. Posteriormente, as quotas tarifárias foram divididas pelo método de administração registrado na OMC. Dessa divisão, foi extraída novamente uma média simples, que resultou no valor médio de preenchimento por método de administração, apresentado na tabela 4.

Tabela 4. Distribuição média do preenchimento das quotas tarifárias pelos principais métodos de administração (média simples), período 19952000, em porcentagem (\%).

\begin{tabular}{lrrrrrrrc}
\hline Método de Administração & 1995 & 1996 & 1997 & 1998 & 1999 & 2000 & 2001 & $\begin{array}{c}\text { Valor Médio } \\
\text { (1995-2001) }\end{array}$ \\
\hline 1. Tarifa Aplicada (TA) & 71 & 65 & 65 & 70 & 70 & 68 & 68 & 68 \\
2. First-Come, First-Served (FC) & 56 & 61 & 47 & 51 & 64 & 60 & 49 & 55 \\
3. Licenças sobre Demanda (LD) & 58 & 57 & 54 & 54 & 51 & 51 & 54 & 54 \\
4. Leilão (LE) & 26 & 32 & 51 & 34 & 23 & 32 & 52 & 36 \\
5. Alocação Histórica (HI) & 91 & 77 & 73 & 69 & 63 & 58 & 65 & 71 \\
6. Empresas Estatais (EE) & 81 & 83 & 90 & 91 & 71 & 72 & 87 & 82 \\
7. Grupos de Produtores (GP) & 74 & 53 & 85 & 78 & 86 & 83 & 85 & 78 \\
8. Outros (OU) & 56 & 61 & 93 & 91 & 99 & 95 & 93 & 84 \\
9. Mix de Métodos (MX) & 74 & 83 & 84 & 84 & 73 & 44 & 79 & 74 \\
10. Não Especificado (NS) & 100 & 44 & 57 & 44 & 41 & 86 & 58 & 61 \\
Preenchimento Global Médio & 66 & 63 & 62 & 63 & 62 & 60 & 62 & 63 \\
\hline
\end{tabular}

Fonte: dados de pesquisa e OMC (2002)

Percebe-se uma certa constância quanto ao percentual de preenchimento das quotas para alguns métodos (tarifa aplicada, licença sobre demanda, alocação histórica e grupo de produtores) e alguma oscilação para os demais métodos de administração. 
DeGorter e Sheldon (2001) apontaram que a média do preenchimento das quotas pode tornar-se viesada porque tanto o volume de comércio quanto o valor de comércio médio não são ponderados. Entretanto, explicam os autores, a ponderação nesse caso pode tornar-se problemática devido às diferentes unidades de medida dentro e entre os países. Mesmo dentro de uma mesma quota tarifária pode ser encontrada uma grande variedade de produtos de diferentes qualidades e valores, o que dificulta sua ponderação.

Vários fatores podem determinar uma taxa baixa de preenchimento, de acordo com Bureau (1999): competitividade do produto doméstico, tarifas intraquota proibitivas, demanda doméstica reduzida ou práticas restritivas de gerenciamento das quotas.

Para essa última observação, cabe destacar Bureau (1999), que afirmou que vários países preferiram calcular seu valor de quota como uma porcentagem do consumo agregado de várias commodities e assim alocar esse valor de quota para o conjunto de commodities, implicando um número reduzido de quotas tarifárias para um grande número de commodities sensíveis; e ainda aponta a utilização de um processo denominado 'dirty quotification ${ }^{16}$, que resultou em um volume de quotas abaixo de $3 \%$ do consumo doméstico. Destacam-se também DeGorter e Sheldon (2001), os quais afirmam que um indicador importante da ineficiência administrativa é o preenchimento de quota inferior a 100\%, ocorrendo importação extraquota. Nesse caso, a questão é determinar se a taxa de preenchimento é proporcionada pela quota ou se as importações intraquota são limitadas, independentemente do nível da quota, o

${ }^{16}$ Dirty quotification (quotificação suja) foi o processo utilizado por alguns países durante a Rodada Uruguai e consiste em se utilizar de vários subterfúgios no intuito de limitar o volume estabelecido como quota, ou seja, manipular o nível de acesso mínimo por meio de cálculos pouco transparentes (Mathews e Laroche-Dupraz, 2002). 
que torna essa questão importante na determinação e efetividade de cenários de liberalização alternativos.

Isso quer dizer que, muitas vezes, o não-preenchimento, como verificado na tabela 4, vincula-se à política comercial adotada por um determinado país, encobrindo o estrito cumprimento dos compromissos de acesso mínimo ou corrente assumidos.

Na tabela 5 é apresentada a distribuição das taxas de preenchimento das quotas, divididas em faixas porcentuais. Essa tabela mostra um nível de preenchimento entre $80 \%$ e $100 \%$ para a maioria dos métodos de administração. Essa característica não é acompanhada pelo método first comefirst served, que tem uma maior freqüência na posição até $20 \%$ de preenchimento. 
Tabela 5. Distribuição média do preenchimento das quotas tarifárias por método de administração, por faixa porcentual, 2001.

\begin{tabular}{lcccccc}
\hline Método de Administração & $0-20 \%$ & $20-40 \%$ & $40-60 \%$ & $60-80 \%$ & $80-100 \%$ & TOTAL \\
\hline 1. Tarifa Aplicada (TA) & 73 & 63 & 54 & 59 & 265 & 514 \\
2. First-Come, First-Served (FC) & 56 & 13 & 17 & 15 & 49 & 150 \\
3. Licenças sobre Demanda (LD) & 80 & 34 & 35 & 45 & 96 & 290 \\
4. Leilão (LE) & 20 & 5 & 3 & 2 & 21 & 51 \\
5. Alocação Histórica (HI) & 23 & 15 & 8 & 12 & 60 & 118 \\
6. Empresas Estatais (EE) & 1 & 1 & 0 & 1 & 17 & 20 \\
7. Grupos de Produtores (GP) & 0 & 1 & 0 & 1 & 7 & 9 \\
8. Outros (OU) & 0 & 0 & 0 & 1 & 6 & 7 \\
9. Mix de Métodos (MX) & 5 & 1 & 2 & 7 & 32 & 47 \\
10. Não Especificado (NS) & 1 & 2 & 1 & 0 & 3 & 7 \\
No Total por Faixa Percentual & 259 & 135 & 120 & 143 & 556 & 1.213 \\
\hline
\end{tabular}

Fonte: dados de pesquisa e WTO (2002) 
O nível baixo de preenchimento do método first come, first served é explicado por Skully (2001a) e Abbott (2001). Os autores dizem que esse comportamento deve-se a uma característica intrínseca ao método, à medida que a quota vai sendo preenchida e passa a dar sinais do seu completo preenchimento, o risco de pagamento da tarifa extraquota aumenta. Nesse caso, é de se esperar um baixo nível de preenchimento para o respectivo método.

Verificam-se também, como comportamento comum, valores maiores nas extremidades, ou seja, maior freqüência nos intervalos até $20 \%$ e de $80 \%$ a 100\%. Esse fato já foi apontado por DeGorter e Sheldon (2001), que indicaram que o preenchimento das quotas tende a seguir uma distribuição bimodal e que atenção particular deve ser dada à determinação, caso a caso, das razões para esse comportamento. Destacam também que os efeitos dos compromissos de acesso a mercado sobre as importações de um país são difíceis de serem isolados dos efeitos de mudanças nas condições de mercados.

Uma taxa reduzida de preenchimento não necessariamente indica ineficiência, uma vez que pode não haver demanda suficiente para a importação do produto em questão. O contrário, preenchimento superior a 100\%, também não significa eficiência para DeGorter e Sheldon (2001), de forma que o preenchimento pode ocorrer com ofertas de produtos de custo de produção elevados, baixa qualidade de produto ou importação seguida a destruição dos produtos importados com a finalidade de redução de oferta e manutenção de preços domésticos. Ou seja, em muitos casos, ineficiência pode estar ligada ao preenchimento das quotas a taxas elevadas.

As estatísticas oficiais da OMC não mostram se ocorreu importação extraquota, de modo que, como demonstrado na tabela 6 , o número de quotas que obtiveram preenchimento total, cerca de $26 \%$ delas, é relativamente baixo ao se considerar que o AARU estabelece que as quotas sejam totalmente 
preenchidas. Nesses casos, pelas estatísticas oficiais não há como verificar se ocorreu ou não preenchimento além da quota, configurando-se em mais uma falha quanto à transparência do sistema.

Tabela 6. Número de quotas tarifárias com preenchimento igual ou acima de 100\%, por método de administração, ano 2001.

\begin{tabular}{lcc}
\hline Método de Administração & Maior ou igual a 100\% & Total \\
\hline 1. Tarifa Aplicada (TA) & 170 & 514 \\
2. First-Come, First-Served (FC) & 32 & 150 \\
3. Licenças sobre Demanda (LD) & 41 & 290 \\
4. Leilão (LE) & 17 & 51 \\
5. Alocação Histórica (HI) & 26 & 118 \\
6. Empresas Estatais (EE) & 10 & 20 \\
7. Grupos de Produtores (GP) & 4 & 9 \\
8. Outros (OU) & 3 & 7 \\
9. Mix de Métodos (MX) & 10 & 47 \\
10. Não Especificado (NS) & 2 & 7 \\
No. Total & 315 & 1.213 \\
\hline
\end{tabular}

Fonte: dados de pesquisa e OMC (2002)

De qualquer forma, o preenchimento das quotas é um tópico que atrai considerável atenção. Dependendo do ponto de vista, o preenchimento médio em torno de $62 \%$, conforme tabela 4 , desde sua implantação pode parecer satisfatório, porém, para outros, pode parecer extremamente reduzido. O estudo caso a caso pode oferecer melhores conclusões sobre essa questão.

Do ponto de vista do Brasil, grande exportador de produtos agroindustriais e com grande capacidade para aumentar a oferta deles no mercado internacional, o preenchimento reduzido das quotas é preocupante. 
Até porque, em muitos casos, o País não possui quotas e, portanto, não consegue obter nenhuma participação em determinados mercados para produtos com quotas tarifárias.

Outro ponto importante a ser ressaltado se refere aos capítulos do sistema harmonizado da OMC em que a incidência de quotas tarifárias é mais expressiva. Essa informação pode ser verificada na tabela 7, obtida a partir de informações oficiais da Secretaria da OMC.

Tabela 7. Número de quotas tarifárias por capítulo do sistema harmonizado da OMC, 2001.

\begin{tabular}{lclc}
\hline \multicolumn{1}{c}{ CAPÍTULO } & $\begin{array}{c}\text { No Quotas } \\
\text { Tarifárias }\end{array}$ & \multicolumn{1}{c}{ CAPÍTULO } & $\begin{array}{c}\text { No Quotas } \\
\text { Tarifárias }\end{array}$ \\
\hline I. Animais vivos & 35 & XIX. Preparações à base de cereais, etc. & 17 \\
II. Carnes & 170 & XX. Preparações de produtos de origem vegetal & 86 \\
IV. Leite, laticínios e ovos & 194 & XXI. Preparações alimentícias diversas & 24 \\
V. Outros produtos de origem animal & 6 & XXII. Bebidas alcoólicas e vinagres & 37 \\
VI. Plantas vivas & 13 & XXIII. Resíduos das indústrias alimentares & 43 \\
VII. Plantas, raízes e tubérculos comestíveis & 171 & XXIV. Fumo (tabaco) & 13 \\
VIII. Frutas & 99 & XXIX. Produtos químicos orgânicos & 1 \\
IX. Café, chá e especiarias & 13 & XXXIII. Óleos essenciais e resinóides & 1 \\
X. Cereais & 138 & XXXV. Matérias albuminóides & 9 \\
XI. Produtos da indústria de moagem & 70 & XXXVIII. Produtos diversos das indústrias químicas & 2 \\
XII. Oleaginosas & 77 & XLI. Peles e couros & 1 \\
XIII. Gomas, resinas & 1 & XLIII. Peleteira & 1 \\
XIV. Matérias de entrançar & 0 & L. Seda & 4 \\
XV. Gorduras & 89 & LI. Lã e pêlos & 2 \\
XVI. Preparações de carne & 21 & LII. Algodão & 1 \\
XVII. Açúcares, confeitaria & 58 & LIII. Fios de papel & 11 \\
XVIII. Cacau & 15 & TOTAL & 3 \\
\hline
\end{tabular}

Fonte: dados de pesquisa e OMC (2002)

Nota: a nomenclatura oficial de cada capítulo está contida no Anexo I. 
Para a confecção dessa tabela, cada quota tarifária foi avaliada a partir de suas linhas tarifárias a oito ou mais dígitos, conforme notificado na $\mathrm{OMC}^{17}$.

Uma vez que de forma geral em uma quota há várias linhas tarifárias, escolheu-se o maior número de linhas de um capítulo dentro de cada quota tarifária como representivo a um capítulo, ou seja, a freqüência maior de um capítulo em uma quota tarifária determinou seu enquadramento neste capítulo. Quando esse critério não pôde ser executado, enquadrou-se a quota tarifária naquele capítulo de maior interesse às exportações brasileiras.

Destaque deve ser dado aos capítulos II (carnes), capítulo IV (leite e derivados), capítulo VII (vegetais) e capítulo X (cereais), por terem maior incidência de quotas tarifárias, caracterizando, assim, aqueles produtos mais sensíveis mundialmente. Vislumbrando a possibilidade de conseguir maior acesso aos produtos agroindustriais brasileiros, pode-se verificar que, em quase todos os capítulos agrícolas, segundo a $\mathrm{OMC}$, existe um número considerável de quotas sendo aplicadas.

\subsection{As quotas tarifárias e o Brasil}

Na seção anterior foram levantadas na OMC algumas estatísticas visando esclarecer a interface entre o nível de preenchimento e métodos de administração. Verificou-se que a incidência das quotas tarifárias não expressa de forma clara comportamentos ou características comuns, de maneira que as quotas tarifárias mostram-se como um instrumento bastante heterogêneo.

\footnotetext{
17 Em muitos casos, as quotas tarifárias apresentam várias linhas tarifárias de diferentes capítulos do sistema harmonizado. Ou seja, dentro de uma quota tarifária, pode-se encontrar diferentes produtos, como, por exemplo, a quota para "misturas contendo mais de $10 \%$ de açúcar" dos Estados Unidos tem dez linhas tarifárias compreendendo quatro capítulos do sistema harmonizado.
} 
A característica de heterogeneidade quanto ao comportamento das quotas tarifárias leva a uma tentativa de reduzir o universo de atuação para aquelas que afetam efetivamente produtos de maior interesse ao Brasil.

Nesse sentido, espera-se que um nível maior de detalhe sobre a adoção do sistema de quotas tarifárias possa demonstrar concretamente o seu comportamento e influência sobre as exportações brasileiras.

Entretanto, primeiramente, o presente trabalho deve definir quais são os produtos de maior interesse ao Brasil?

\subsection{Os produtos de maior interesse ao Brasil}

Para apontar quais os produtos agroindustriais de maior interesse ao Brasil no comércio internacional, partiu-se da pauta total das exportações do agronegócio brasileiro para um período representativo. O período escolhido foi o triênio 2000-2002, por ser considerado aquele em que o País tornou-se mais competitivo devido às condições de política econômica adotadas pelo seu governo, ou seja, quando o reflexo do protecionismo internacional pode ser mais bem avaliado.

Foram coletados os valores mensais das exportações e identificados os produtos de 12 sistemas agroindustriais (SAGs) de importância estratégica ao Brasil a partir de informações disponíveis na Secretaria de Comércio Exterior (Secex), do Ministério do Desenvolvimento, Indústria e Comércio Exterior $(\mathrm{MDIC})^{18}$.

\footnotetext{
${ }^{18}$ As quotas tarifárias incidem sobre os produtos agroindustriais conforme definido pela OMC. Essa definição assume que os produtos agroindustriais são compreendidos pelos capítulos do sistema harmonizado, exceto aqueles produtos e suas preparações originados da atividade pesqueira, posições 2905.43, 2905.44, 3301, 3501 a 3505, 3809.10, 3823.60, 4101 a 4103, 4301, 5001 a 5003, 5101 a 5103, 5201 a 5203, 5301 e 5302. Assim, excluem-se os SAGs da madeira, papel e celulose, borracha, têxteis e calçados de couro, entre outros, também muito importantes às exportações brasileiras e considerados pelas autoridades do Brasil como produtos agroindustriais. (World Trade Organization, The Legal Texts, The Results of the Uruguay Round of Multilateral Trade Negotiations, 1999, p.47)
} 
Os 12 SAGs identificados são compostos por complexo soja, açúcar e álcool, café, carnes de aves, carne bovina, suco de frutas, fumo, carne suína, frutas, milho, cacau e algodão. Esses produtos reunidos representam 93,32\% das exportações do agronegócio brasileiro no período analisado.

Posteriormente esses SAGs foram desagregados em linhas tarifárias a oito dígitos, seguindo a Nomenclatura Comum do Mercosul (NCM), de forma a ser possível identificar as linhas dos produtos que mais contribuíram às exportações médias anuais de cada um dos complexos agroindustriais.

Essa identificação seguiu os seguintes parâmetros: para todos os SAGs, exceto para as frutas, foram selecionadas as linhas tarifárias que representaram mais de $10 \%$ das exportações do sistema. Para as frutas, o porcentual utilizado foi de $5 \%$. Cabe ressaltar que foram selecionados alguns produtos-chave, que, mesmo não representando $10 \%$ das exportações totais dos respectivos complexos, salientam-se por seu grau de diferenciação, como álcool etílico e carne de peru, ou pelo alto volume de exportações, como o óleo de soja.

Dessa forma, foram obtidas 32 linhas tarifárias, as quais representam $88 \%$ das exportações agroindustriais brasileiras, como demonstrado na tabela 8 , e constituem o universo de produtos em que este trabalho vai se concentrar a partir de agora.

Cabe ressaltar que as quotas tarifárias do capítulo XVI, por incluírem vários tipos de carnes - bovina, suína e de aves, entre outras -, não foram contabilizadas, embora conste da tabela 8 a alínea 1602.50.00. Vale lembrar que este produto é importante na pauta exportadora do agronegócio brasileiro.

Fica, portanto, determinado que este trabalho trata de 32 produtos que representam $88 \%$ da pauta exportadora brasileira vinculada ao agronegócio. 
Tabela 8. Principais produtos do agroindustriais da pauta exportadora brasileira: média 2000-2002, número de quotas tarifárias por produto e taxa de preenchimento mundial de quotas (\%).

\begin{tabular}{|c|c|c|c|c|}
\hline Produto & $\begin{array}{c}\text { Valor } \\
\text { US\$ Milhões }\end{array}$ & $\begin{array}{l}\text { Participação } \\
\text { Total (\%) }\end{array}$ & № Quotas & $\begin{array}{c}\text { Taxa de } \\
\text { Preenchimento } \\
\text { Mundial de Quotas }\end{array}$ \\
\hline Soja - grão & $2.641,6$ & 17,2 & 8 & 87,2 \\
\hline Soja - farelo & $1.968,9$ & 12,9 & 7 & 78,0 \\
\hline Soja - óleo & 462,3 & 3,0 & 7 & 83,3 \\
\hline Açúcar bruto & $1.089,2$ & 7,1 & 26 & 69,8 \\
\hline Açúcar - outros & 765,3 & 5,0 & 32 & 62,3 \\
\hline Álcool etílico & 97,6 & 0,6 & 9 & 42,6 \\
\hline Café - grão & $1.314,0$ & 8,6 & 6 & 64,6 \\
\hline Café solúvel & 184,6 & 1,2 & 2 & 39,3 \\
\hline Café torrado & 4,2 & 0,0 & 0 & - \\
\hline Frango - inteiro congelado & 705,3 & 4,6 & & \\
\hline Frango - pedaço congelado & 438,4 & 2,9 & 53 & 50,4 \\
\hline Peru - pedaços congelado & 89,9 & 0,6 & & \\
\hline Carne bovina, congelada & 447,2 & 2,9 & & \\
\hline Carne bovina, preparações & 267,2 & 1,7 & 53 & 56,7 \\
\hline Carne bovina, refrigerada & 225,1 & 1,5 & & \\
\hline Suco de laranja & 900,1 & 5,9 & 6 & 84,8 \\
\hline Tabaco & 809,3 & 5,3 & 13 & 70,4 \\
\hline Carne suína - outros & 219,0 & 1,4 & & \\
\hline Carne suína - congelada & 82,0 & 0,5 & 44 & 52,2 \\
\hline Carne suína - refrigerada & 19,0 & 0,1 & & \\
\hline Castanha de caju & 127,4 & 0,8 & 0 & - \\
\hline Melão & 45,6 & 0,3 & 3 & 81,5 \\
\hline Mamão & 34,0 & 0,2 & 1 & 22,8 \\
\hline Manga & 23,2 & 0,2 & 1 & - \\
\hline Uva & 20,6 & 0,1 & 7 & 52,4 \\
\hline Banana & 19,2 & 0,1 & 4 & 98,7 \\
\hline Laranja & 17,0 & 0,1 & 6 & 66,0 \\
\hline Milho & 241,9 & 1,6 & 38 & 72,6 \\
\hline Manteiga de cacau & 63,0 & 0,4 & & \\
\hline Chocolates & 54,4 & 0,4 & 15 & 25,1 \\
\hline Chocolate em pó & 21,2 & 0,1 & & \\
\hline Algodão & 88,9 & 0,6 & 11 & 34,3 \\
\hline TOTAL PRODUTOS & $13.486,6$ & 88,0 & 352 & 61,7 \\
\hline TOTAL GERAL & $15.320,8$ & 100,0 & 1425 & 62,0 \\
\hline
\end{tabular}

Fonte: dados de pesquisa, Brasil (2003) e WTO (2002) 


\subsection{A incidência de quotas tarifárias}

Considerando, portanto, a tabela 8 , identificou-se o número de quotas tarifárias incidentes em cada uma daquelas linhas tarifárias. Ressalta-se que as linhas tarifárias somente estão harmonizadas até o sexto dígito. Nesse sentido, estabelecer a estrita equivalência entre os números de classificação dos produtos entre os países nem sempre é uma tarefa simples. Para que pudessem ser comparadas, foi realizada a identificação daquelas linhas correspondentes aos produtos brasileiros selecionados seguindo uma ordem de parâmetros.

Primeiramente, procurou-se verificar a existência de equivalência estrita entre o número NCM e a descrição praticadas pelo Brasil e o quadro tarifário do parceiro comercial. Quando não foi possível essa equivalência exata, procurou-se uma "quase-equivalência", ou seja, descrições muito próximas capazes de, na prática, representarem o mesmo produto.

Quando ainda não foi possível essa identificação, foram analisados todos os produtos com os seis primeiros dígitos (harmonizados mundialmente) semelhantes ao do produto brasileiro, buscando a descrição a oito ou mais dígitos que mais se aproximasse dele.

Utilizando-se esse método, foram identificadas as linhas correspondentes aos produtos escolhidos naqueles países que impõem quotas tarifárias. Posteriormente, a partir dos quadros de tarifas consolidadas, publicados pela Organização Mundial do Comércio, buscou-se a presença dessas linhas tarifárias em cada uma das quotas tarifárias, de tal sorte que, havendo a presença do número correspondente ao produto, essa quota passa a ser contabilizada como restrição às exportações brasileiras; do contrário, é deixada de lado, ficando à espera de trabalhos futuros. 
Verifica-se, a partir da tabela 8, a grande incidência de quotas tarifárias no açúcar bruto de cana, em outros açúcares, nas carnes de aves, bovinas e suínas e no milho. Cabe destacar que, no item "açúcar - outros", encontra-se o açúcar refinado de cana, do qual o Brasil é grande produtor; no item carnes de aves, embora dividido em três produtos principais, devido à grande incidência de quotas que não diferenciam carnes congeladas das refrigeradas ou carnes de frango das de peru, estas quotas tarifárias não puderam ser expressas separadamente, portanto, foram expressas de forma conjunta, de tal sorte que, uma vez que fosse encontrada uma linha tarifária correspondente a um dos três produtos escolhidos, esta foi escolhida como representativa, o mesmo acontecendo para carne bovina, carne suína e os derivados de cacau.

Utilizando-se também as informações oficiais publicadas pela OMC, calculou-se o nível de preenchimento médio das quotas para o período de 1995 a 2001. Cabe ressaltar que as informações, em muitos casos, encontravam-se incompletas e desencontradas, o que dificultou a agregação e a análise.

Como informações mais recentes não foram encontradas, optou-se então pelo cálculo da média simples de todos os anos como estatística mais vigorosa para explicar o comportamento do preenchimento das quotas. E ainda, quando não foram encontradas informações sobre todos os anos, calculou-se a média das informações disponíveis.

Percebe-se que é comum não ocorrer o preenchimento completo em nenhum dos produtos escolhidos. Destacam-se café solúvel, mamão e derivados de cacau, estes com menor índice de preenchimento médio.

Entretanto, conforme já apontado por DeGorter e Sheldon (2001), o preenchimento da quota não é uma boa estatística para comparação, pois uma quota tarifária de 16 toneladas pode ter o mesmo nível de preenchimento que 
outra de 1.600 toneladas. Porém, como apontado anteriormente, um esquema de ponderação é problemático.

O critério de cálculo dos níveis de preenchimento das quotas é adotado pela OMC em seus relatórios e estudos, uma vez que é uma das poucas estatísticas que podem ser calculadas sem grandes dificuldades. Embora essa abordagem tenha uma série de limitações, é importante para distinguir o regime ao qual a quota responde - se regime intraquota, extraquota ou quota.

Nesse caso, se não houver preenchimento da quota, configura-se um caso intraquota; se existir preenchimento de 100\%, dois casos serão possíveis: um regime quota, caso não haja importação além da quota, ou o contrário, o que configurará um regime extraquota.

Comparações entre número de quotas e nível de preenchimento não trazem afirmações conclusivas, porque não existe como verificar alguma correlação entre ambas a partir das informações disponíveis.

\subsection{Os países que impõem quotas tarifárias}

A seção anterior mostrou que o processo de quantificação das quotas tarifárias torna-se tanto mais complicado à medida que se queira atingir um maior grau de detalhamento. Trata-se do efeito direto da falta de transparência empiricamente verificada neste presente trabalho.

A tabela 9 mostra o número de quotas tarifárias por país para aqueles produtos de maior interesse brasileiro. Verifica-se que, das 1.425 quotas tarifárias registradas, os produtos brasileiros escolhidos sofrem restrições em apenas 352 e em 38 dos 43 países que registraram suas quotas. 
Tabela 9. Número de quotas tarifárias para os principais produtos brasileiros, ano 2001.

\begin{tabular}{lclc}
\hline País Membro & $\begin{array}{c}\text { № Quotas } \\
\text { Tarifárias }\end{array}$ & País Membro & $\begin{array}{c}\text { № Quotas } \\
\text { Tarifárias }\end{array}$ \\
\hline 1. África do Sul & 14 & 23. Japão & - \\
2. Austrália & 1 & 24. Letônia & 1 \\
3. Barbados & 9 & 25. Lituânia & 3 \\
4. Brasil & - & 26. Malásia & 10 \\
5. Bulgária & 33 & 27. Marrocos & 5 \\
6. Canadá & 3 & 28. México & 4 \\
7. Chile & 1 & 29. Nicarágua & 4 \\
8. China & 4 & 30. Noruega & 23 \\
9. Colômbia & 20 & 31. Nova Zelândia & - \\
10. Coréia do Sul & 9 & 32. Panamá & 3 \\
11. Costa Rica & 7 & 33. Polônia & 18 \\
12. Croácia & 8 & 34. Rep. Dominicana & 3 \\
13. Equador & 7 & 35. Rep. Eslovaca & 6 \\
14. El Salvador & 6 & 36. Rep. Checa & 7 \\
15. Eslovênia & 13 & 37. Romênia & 5 \\
16. Estados Unidos & 18 & 38. Suíça & - \\
17. Filipinas & 7 & 39. Tailândia & 8 \\
18. Guatemala & 10 & 40. Taiwan & 7 \\
19. Hungria & 14 & 41. Tunísia & 2 \\
20. Indonésia & - & 42. União Européia & 30 \\
21. Islândia & 12 & 43. Venezuela & 13 \\
22. Israel & 3 & TOTAL (43 países) & 352 \\
\hline
\end{tabular}

Fonte: dados de pesquisa e OMC (2002)

Nessa tabela, destacam-se União Européia e Bulgária, com 30 e 33 quotas tarifárias respectivamente aplicadas a produtos de maior interesse ao 
Brasil, países com maior número de quotas para esses produtos. Outra constatação importante é que o Japão, grande mercado consumidor, não impõe nenhuma quota tarifária para os produtos escolhidos.

A Noruega também chama a atenção, por impor aos produtos de interesse somente 23 quotas, cerca de $10 \%$ de todo seu universo, que totaliza 232 quotas tarifárias.

\subsection{O comportamento dos componentes das quotas tarifárias}

Mas como se comportam as quotas tarifárias impostas sobre os produtos de maior interesse ao Brasil?

A tabela 10 demonstra o preenchimento médio das quotas para cada um dos produtos escolhidos. Cabe destacar que as informações disponíveis são relativamente pouco detalhadas e de série temporal curta (apenas sete anos), o que impede o cálculo de estatísticas mais apuradas e complexas. 
Tabela 10. Preenchimento de quotas tarifárias por produto e faixa de preenchimento.

\begin{tabular}{|c|c|c|c|c|c|c|c|}
\hline \multirow[b]{2}{*}{ PRODUTO } & \multirow{2}{*}{ № QUOTAS } & \multirow{2}{*}{$\begin{array}{l}\text { PREENCHIMENTO } \\
\text { MÉDIO (\%) }\end{array}$} & \multicolumn{5}{|c|}{ NÚMERO DE QUOTAS TARIFÁRIAS POR FAIXA DE PREENCHIMENTO } \\
\hline & & & Até 25\% & $25 \%-50 \%$ & $50 \%-75 \%$ & $75 \%-100 \%$ & N.D. \\
\hline Soja - grão & 8 & 87,2 & 0 & 1 & 1 & 6 & 0 \\
\hline Soja - farelo & 7 & 78,0 & 0 & 1 & 2 & 4 & 0 \\
\hline Soja - óleo & 7 & 83,3 & 0 & 1 & 0 & 4 & 2 \\
\hline Açúcar bruto & 26 & 69,8 & 3 & 3 & 0 & 11 & 9 \\
\hline Açúcar - outros & 32 & 62,3 & 9 & 1 & 3 & 16 & 3 \\
\hline Álcool etílico & 9 & 42,6 & 4 & 0 & 2 & 3 & 0 \\
\hline Café - grão & 6 & 64,6 & 1 & 1 & 0 & 3 & 1 \\
\hline Café solúvel & 2 & 39,3 & 0 & 2 & 0 & 0 & 0 \\
\hline Café torrado & 0 & - & - & - & - & - & - \\
\hline Frango - inteiro congelado & & & & & & & \\
\hline $\begin{array}{l}\text { Frango - pedaço congelado } \\
\text { Peru - pedaço congelado }\end{array}$ & 53 & 50,4 & 17 & 8 & 5 & 16 & 7 \\
\hline Carne bovina, congelada & & & & & & & \\
\hline $\begin{array}{l}\text { Carne bovina, preparações } \\
\text { Carne bovina, refrigerada }\end{array}$ & 53 & 56,7 & 12 & 7 & 8 & 16 & 9 \\
\hline Suco de laranja & 6 & 84,8 & 0 & 0 & 1 & 5 & 0 \\
\hline Tabaco & 13 & 40,4 & 1 & 2 & 2 & 6 & 3 \\
\hline
\end{tabular}


Tabela 10. Preenchimento de quotas tarifárias por produto e faixa de preenchimento.

\begin{tabular}{|c|c|c|c|c|c|c|c|}
\hline \multirow[b]{2}{*}{ PRODUTO } & \multirow{2}{*}{ № QUOTAS } & \multirow{2}{*}{$\begin{array}{l}\text { PREENCHIMENTO } \\
\text { MÉDIO (\%) }\end{array}$} & \multicolumn{5}{|c|}{ NÚMERO DE QUOTAS TARIFÁRIAS POR FAIXA DE PREENCHIMENTO } \\
\hline & & & Até $25 \%$ & $25 \%-50 \%$ & $50 \%-75 \%$ & $75 \%-100 \%$ & N.D. \\
\hline Carne suína - outros & & & & & & & 7 \\
\hline Carne suína - congelada & 44 & 52,2 & 11 & 5 & 9 & 12 & \\
\hline \multicolumn{8}{|l|}{ Carne suína - refrigerada } \\
\hline Castanha de caju & 0 & - & - & - & - & - & - \\
\hline Melão & 3 & 81,5 & 0 & 0 & 0 & 2 & 1 \\
\hline Mamão & 1 & 22,8 & 1 & 0 & 0 & 0 & 0 \\
\hline Manga & 1 & - & - & - & - & - & - \\
\hline Uva & 7 & 52,4 & 3 & 0 & 0 & 3 & 1 \\
\hline Banana & 4 & 98,7 & 0 & 0 & 0 & 2 & 2 \\
\hline Laranja & 6 & 66,0 & 0 & 2 & 1 & 2 & 1 \\
\hline Milho & 38 & 72,6 & 6 & 1 & 6 & 19 & 6 \\
\hline \multicolumn{8}{|l|}{ Manteiga de cacau } \\
\hline Chocolates & 15 & 25,1 & 8 & 0 & 3 & 1 & 3 \\
\hline \multicolumn{8}{|l|}{ Chocolate em pó } \\
\hline Algodão & 11 & 34,3 & 5 & 1 & 0 & 2 & 2 \\
\hline TOTAL & 352 & 61,7 & 81 & 36 & 43 & 133 & 67 \\
\hline
\end{tabular}

Fonte: dados de pesquisa e WTO (2002) 
Entretanto, verifica-se que complexo soja, suco de laranja e tabaco possui uma certa concentração de preenchimento para o intervalo entre $75 \%$ e $100 \%$. No caso do complexo soja, nota-se ainda uma boa participação em quotas totalmente preenchidas. O mesmo ocorre para açúcar bruto e álcool etílico.

Açúcar - outros, carne de aves, carne bovina e carne suína apontam para uma situação bimodal, ou seja, concentração de níveis de preenchimento entre os extremos nesse caso. Isso impede uma definição precisa de comportamento. Já para derivados de cacau e algodão, percebe-se uma nítida concentração no intervalo até $25 \%$, ou seja, esses produtos têm uma história de baixo preenchimento das quotas.

Frutas e café, devido ao número muito pequeno de informações, impedem avaliações conclusivas.

A última coluna descreve o número de informações não disponíveis. Ou seja, do universo de 352 observações, apenas 293 estão disponíveis. Isso reflete mais uma restrição ao estudo do sistema de quotas tarifárias, séries pequenas de dados que acabam por limitar as possibilidades de aferições estatísticas.

A tabela 11 traz as tarifas médias intraquota e extraquota mundiais impostas sobre os produtos de maior interesse ao Brasil. Essas tarifas foram coletadas no Economic Research Service (ERS), do Departamento de Agricultura dos Estados Unidos (USDA). 
Tabela 11. Tarifas médias intraquota e extraquota por produto.

\begin{tabular}{|c|c|c|}
\hline Produto & $\begin{array}{c}\text { Tarifa Média } \\
\text { Intraquota (\%) }\end{array}$ & $\begin{array}{c}\text { Tarifa Média } \\
\text { Extraquota (\%) }\end{array}$ \\
\hline Soja - grão & 45,8 & 135,7 \\
\hline Soja - farelo & 56,0 & 78,0 \\
\hline Soja - óleo & 28,6 & 102,3 \\
\hline Açúcar bruto & 51,9 & 89,0 \\
\hline Açúcar - outros & 75,1 & 104,9 \\
\hline Álcool etílico & 137,0 & 170,7 \\
\hline Café - grão & 25,0 & 67,4 \\
\hline Café solúvel & 50,0 & 50,1 \\
\hline Café torrado & 37,5 & 72,0 \\
\hline \multicolumn{3}{|l|}{ Frango - inteiro congelado } \\
\hline Frango - pedaço congelado & 61,9 & 150,0 \\
\hline \multicolumn{3}{|l|}{ Peru - pedaço congelado } \\
\hline \multicolumn{3}{|l|}{ Carne bovina, congelada } \\
\hline Carne bovina, preparações & 53,3 & 136,5 \\
\hline \multicolumn{3}{|l|}{ Carne bovina, refrigerada } \\
\hline Suco de laranja & 95,0 & 143,0 \\
\hline Tabaco & 123,6 & 389,1 \\
\hline \multicolumn{3}{|l|}{ Carne suína - outros } \\
\hline Carne suína - congelada & 58,3 & 111,2 \\
\hline \multicolumn{3}{|l|}{ Carne suína - refrigerada } \\
\hline Castanha de caju & - & - \\
\hline Melão & 62,3 & 72,3 \\
\hline Mamão & 103,0 & 147,0 \\
\hline Manga & - & - \\
\hline Uva & 25,7 & 45,1 \\
\hline Banana & 19,6 & 80,9 \\
\hline Laranja & 27,5 & 43,9 \\
\hline Milho & 68,5 & 102,4 \\
\hline \multicolumn{3}{|l|}{ Manteiga de cacau } \\
\hline Chocolates & 35,8 & 57,2 \\
\hline \multicolumn{3}{|l|}{ Chocolate em pó } \\
\hline Algodão & 37,1 & 57,9 \\
\hline TARIFA MÉDIA TOTAL & 58,1 & 109,4 \\
\hline
\end{tabular}

Fonte:dados de pesquisa e United States Agricultural Department (USDA) (2003) 
A metodologia aplicada pelo ERS/USDA segue os seguintes critérios:

1) Os dados primários sobre os níveis tarifários praticados constantes da base de dados do ERS/USDA foram extraídos da Agricultural Market Access Database (AMAD), uma base de dados pública bastante completa que contém dados detalhados sobre tarifas consolidadas e quotas tarifárias, importação-exportação, tarifas aplicadas, produção, consumo e comércio, entre outras informações;

2) As informações não contidas na base de dados $A M A D$ foram coletadas da Secretaria da OMC (WTO Secretariat), United Nations Conference on Trade and Development (UNCTAD), por meio de uma base de dados denominada Trade Analysis and Information System (TRAINS);

3) As tarifas são apresentadas por grupo de produto. No caso das quotas tarifárias, foram calculadas as médias tarifárias de todas as alíneas constantes de cada quota.

Cabe destacar que as tarifas podem ser apresentadas de três formas: ad valorem, específicas ou mistas. A primeira é aquele expressa como uma porcentagem do valor do produto, a segunda como unidades monetárias por quantidade de produto e a terceira possui componentes das duas formas anteriores.

No caso das tarifas específicas e mistas, faz-se necessária uma advalorização, ou seja, a transformação dessas tarifas em seus equivalentes ad valorem (EAV).

O ERS/USDA calculou os EAVs dividindo a tarifa específica pelo preço do produto. Para tanto, utilizou um vetor de preço calculado a partir dos valores e quantidades unitários de importação como uma Proxy dos preços realmente praticados. 
As informações sobre preço foram coletadas da United Nations Trade Data System (COMTRADE), utilizando-se valores médios calculados para o período de 1995-97. Para países que não expressam suas tarifas em dólares, o ERS/USDA as converteu utilizando a taxa de câmbio média do período adotado.

Para ilustrar o processo de advalorização, usando o exemplo do ERS/USDA, atente: utilizando dados da AMAD, a tarifa consolidada extraquota para queijo tipo cheddar dos Estados Unidos, alínea 0406.10.28, tem valor de US\$ 1,277/quilograma $(\mathrm{kg})$. Para calcular o EAV, é necessário dividir a tarifa específica pelo seu preço. Esse preço para 1995-97 para a posição 0406.10 é de US\$2,936/kg. O EAV será de 43,5\% (\$1,277 / 2,936 = 0,435).

Cabe ressaltar que a instituição americana não disponibiliza informações para algumas nações, como China, Chile e alguns países do Leste Europeu.

Posteriormente, foram identificadas as quotas tarifárias incidentes sobre produtos brasileiros escolhidos, e calculou-se a média aritmética das tarifas impostas pelos diversos países.

Verifica-se que em média até tarifas intraquota são elevadas se considerarmos como pico tarifário os níveis adotados de tarifas consolidadas na OMC para produtos industriais de 15\% (Gibson et al., 2001). Nesse caso, notase em todos os casos a presença de picos tarifários já na tarifas intraquota.

Se levarmos em conta o critério apontado por Gibson et al. (2001) de considerar pico tarifário de produtos agrícolas aquelas tarifas superiores a $100 \%$, ainda assim, teríamos três casos incidentes já na tarifa intraquota, que teoricamente não deveria ser proibitiva. 
Esse autor também calculou a tarifa média para todos os produtos agrícolas igual a $62 \%$ e tarifa média extraquota igual a $128 \%$. O valor calculado para os produtos de maior interesse ao Brasil é um pouco menor - igual a $109,4 \%$-, no entanto permanece muito alto.

De qualquer forma, os níveis tarifários praticados como intraquota são elevados se comparados com aqueles praticados pela indústria e alguns produtos de origem agrícola pouco sensíveis. Níveis tarifários dessa magnitude são um grande inibidor de comércio.

Tarifas extraquota são, em média, maiores do que $100 \%$, o que as tornam proibitivas.

Ao compararmos a tabela 11 com a 10, não se encontra correlação entre o nível de preenchimento e os níveis tarifários praticados, tampouco com a diferença entre os níveis tarifários extra e intraquota.

A tabela 12 mostra a distribuição dos métodos de administração entre os produtos de maior interesse ao Brasil. 
Tabela 12. Distribuição de quotas tarifárias por método de administração e por produto $^{(1)}$.

\begin{tabular}{|c|c|c|c|c|c|c|c|c|c|c|c|}
\hline PRODUTOS & TOTAL & TA & FC & LD & LE & $\mathrm{HI}$ & $\mathrm{EE}$ & GP & OU & $\mathrm{MX}$ & NS \\
\hline Soja - Grão & 8 & 3 & 1 & 1 & - & 1 & - & 1 & - & 1 & - \\
\hline Soja - farelo & 7 & 4 & - & - & - & 2 & - & 1 & - & - & - \\
\hline Soja - óleo & 7 & 3 & - & - & - & 2 & - & 1 & - & - & 1 \\
\hline Açúcar bruto & 28 & 9 & 3 & 5 & - & 6 & - & - & - & - & 5 \\
\hline Açúcar - outros & 29 & 14 & 10 & 3 & - & - & - & - & - & - & 2 \\
\hline Álcool etílico & 9 & 3 & 2 & 3 & - & 1 & - & - & - & - & - \\
\hline Café - grão & 6 & 3 & - & 2 & - & 1 & - & - & - & - & - \\
\hline Café soluble & 2 & - & - & 2 & - & - & - & - & - & - & - \\
\hline Café torrado & - & - & - & - & - & - & - & - & - & - & - \\
\hline Carne de aves & 55 & 13 & 5 & 18 & 7 & 5 & - & - & 1 & 2 & 2 \\
\hline Carne bovina & 53 & 13 & 10 & 20 & 2 & 3 & - & - & - & 2 & 3 \\
\hline Suco de laranja & 5 & 3 & - & - & - & 2 & - & - & - & - & - \\
\hline Tabaco & 13 & 7 & 1 & 2 & - & 1 & 1 & - & - & 1 & - \\
\hline Carne suína & 39 & 13 & 4 & 15 & 2 & 1 & - & - & - & - & 4 \\
\hline Castanha de caju & - & - & - & - & - & - & - & - & - & - & - \\
\hline Melão & 3 & 2 & - & 1 & - & - & - & - & - & - & - \\
\hline$\underset{\sim}{\text { Mamão }}$ & 1 & 1 & - & - & - & - & - & - & - & - & - \\
\hline Manga & 1 & - & - & - & - & - & - & - & - & - & 1 \\
\hline Uva & 7 & 2 & 2 & 3 & - & - & - & - & - & - & - \\
\hline Banana & 4 & 1 & - & 1 & - & 1 & - & - & - & - & 1 \\
\hline Laranja & 7 & 2 & 2 & 1 & - & - & - & - & - & 1 & 1 \\
\hline Milho & 37 & 19 & 3 & 10 & - & 4 & 1 & - & - & - & - \\
\hline Derivados de cacau & 15 & 3 & 9 & 1 & - & - & - & - & - & - & 2 \\
\hline Algodão & 11 & 2 & 7 & 1 & - & - & - & - & - & - & 1 \\
\hline TOTAL & & 120 & 59 & 89 & 11 & 30 & 2 & 3 & 1 & 7 & 23 \\
\hline
\end{tabular}

Fonte: dados de pesquisa e OMC (2002)

Nota: (1) TA (Tarifa aplicada), FC (First come, first served), LD (Licenças sobre demanda), LE (Leilão), HI (Alocação histórica), EE (Empresas estatais), GP (Grupo de produtores), OU (outros), MX (Mix de métodos de administração) e NS (Não especificado). 
Essa tabela confirma a tendência de maior adoção do método da tarifa aplicada, seguida de licenças sobre demanda e first come, first served.

Ao compararmos essa tabela com a 10, não se consegue uma avaliação conclusiva. Verifica-se, entretanto, que as carnes de aves, bovina e suína, que utilizam largamente os métodos tarifa aplicada e licença sobre demanda de forma parecida, têm concentração de preenchimento nos dois extremos, ou seja, há a indicação de que, ao se utilizar os dois métodos de administração, exista interferência quanto ao preenchimento, que terá comportamento bimodal.

Já era de se esperar um comportamento muito heterogêneo das quotas tarifárias avaliadas de forma agregada. Gibson et al. (2001) destacaram que existem diferenças notáveis entre as quotas tarifárias empregadas em diversas regiões e em várias commodities, e que seu papel varia significativamente.

DeGorter e Sheldon (2001) apontam que informações adicionais sobre a relação entre os preços domésticos e mundiais ajudariam a iluminar a discussão a respeito do sistema de quotas tarifárias e acesso a mercado. Entretanto, na maioria dos casos, as especificidades das quotas (geralmente com muitos produtos diferentes e várias linhas tarifárias numa única quota) descaracterizam as comparações, o que implica a utilização de indicadores imperfeitos para avaliação dos impactos do sistema sobre os mercados.

\subsection{Uma análise país-produto}

Este trabalho apresentou até o momento um quadro geral das quotas tarifárias impostas em diferentes mercados aos principais produtos agroindustriais da pauta exportadora brasileira, valores de tarifas aplicadas, métodos de administração e o comportamento do preenchimento das quotas. 
Esta seção pretende, a partir da confecção de tabelas contendo o nível médio de preenchimento das quotas, tarifa intraquota, tarifa extraquota, volume das quotas e método de administração adotado por país vislumbrar a forma como as quotas são impostas e sob quais tarifas, e verificar características particulares de cada país quanto à aplicação das quotas tarifárias. Por meio da verificação das tarifas impostas e do nível de preenchimento de cada quota tarifária em relação à média, pretende-se apontar quais países tendem a ser mais protecionistas.

Será realizada uma análise descritiva a partir das informações contidas em documentos da Secretaria da OMC e do ERS/USDA sobre os instrumentos das quotas tarifárias aplicadas em 26 países. Essas nações foram escolhidas por possuírem todas as informações pertinentes. A impossibilidade de conseguir informações confiáveis para os outros 12 países impediu que eles fossem incorporados a essa análise.

As 26 nações, com a finalidade de encontrar comportamentos comuns quanto à adoção das quotas tarifárias, serão organizadas por blocos econômicos ou por localização geográfica, a saber: países da Área de Livre Comércio da América do Norte - NAFTA (Estados Unidos, Canadá e México), países da Comunidade Andina (Colômbia, Equador e Venezuela), países centro-americanos e do Caribe (Barbados, Guatemala e Panamá), países asiáticos (Coréia do Sul, Filipinas, Malásia e Tailândia), países do Leste Europeu (Eslovênia, Hungria, Polônia, República Eslovaca e República Checa), países nórdicos (Islândia e Noruega), países africanos (África do Sul, Marrocos e Tunísia), e de forma individualizada, União Européia, Austrália e Israel.

Para essa análise, foi verificada, a partir da base de dados do Sistema ALICE, da Secretaria de Comércio Exterior (Secex), do Ministério do Desenvolvimento, Indústria e Comércio exterior (MDIC), a ocorrência ou não de exportações brasileiras para os 26 países indicados, para as respectivas linhas 
tarifárias dos produtos que são protegidos por quotas tarifárias. O período de referência são os anos de 2000 a 2002.

Esse procedimento pretende Ter um indicativo de que o Brasil possui participação em cada um desses mercados, ou seja, quota para cada um dos produtos.

Cabe ressaltar que esse procedimento não garante que a exportação efetivada pelo Brasil seja uma exportação intraquota, entretanto, dados os níveis tarifários e as características das quotas tarifárias apresentadas neste trabalho, a presença de exportação brasileira em linhas tarifárias sujeitas a quotas tarifárias é um forte indicativo de que o Brasil tem participação nas quotas. Contudo, essas exportações podem também estar ligadas a acordos bilaterais ou preferenciais sujeitos a tarifas reduzidas, ou ainda, tratar-se de uma exportação extraquota.

O reconhecimento preciso da exportação brasileira intraquota deveria considerar a legislação e documentação aduaneira pertinente a cada país para cada um dos produtos escolhidos, bem como identificar a presença em cada uma das linhas tarifárias, acordos bilaterais, regionais ou preferenciais, o que foge aos objetivos do presente trabalho.

\subsection{Países da Área de Livre Comércio da América do Norte (NAFTA)}

A Área de Livre Comércio da América do Norte, composta por Estados Unidos, Canadá e México, merece especial atenção por tratar-se de um bloco comercial que representa uma parte considerável do mercado consumidor mundial, além do seu envolvimento direto com a criação da Área de Livre Comércio das Américas, a qual também tem envolvimento direto do Brasil. Nesse caso, o agrupamento e as decisões desses países certamente influenciam as decisões brasileiras nas suas negociações comerciais. 
Quanto ao sistema de quotas tarifárias, foco central do presente trabalho, o Canadá impõe três quotas tarifárias sobre os produtos agroindustriais brasileiros escolhidos. A tabela 13 ilustra que são impostas duas para carne de aves e uma para carne bovina, todas com nível alto de preenchimento.

Tabela 13. Informações sobre produtos agroindustriais de interesse ao Brasil sujeitos a quotas tarifárias na Área de Livre Comércio da América no Norte (NAFTA).

\begin{tabular}{|c|c|c|c|c|c|c|c|}
\hline País & Produto & $\begin{array}{c}\text { Método de } \\
\text { Administração }\end{array}$ & $\begin{array}{c}\text { Taxa de } \\
\text { Preenchimento }\end{array}$ & $\begin{array}{c}\text { Tarifa } \\
\text { Intra-Quota }\end{array}$ & $\begin{array}{c}\text { Tarifa } \\
\text { Extra-Quota }\end{array}$ & Quota (Ton) & $\begin{array}{l}\text { Ocorrência de } \\
\text { Exportações } \\
\text { Brasileiras }\end{array}$ \\
\hline \multirow{7}{*}{$\begin{array}{c}\text { ESTADOS } \\
\text { UNIDOS }\end{array}$} & Açúcar bruto & FC & 99,5 & 4 & 93,8 & 1.117 .195 & $x$ \\
\hline & Açúcar - outros & $5 F C$ & 68 & 8 & 40,4 & 102.500 & $x$ \\
\hline & Carne bovina & FC & 67,8 & 4,9 & 26,4 & 696.621 & $x$ \\
\hline & Tabaco & FC & 59,3 & 20,3 & 350 & 112.950 & $x$ \\
\hline & Derivados de Cacau & $3 F C$ & 42,1 & 5,7 & 22,8 & 30.604 & $x$ \\
\hline & Algodão & $7 F C$ & 14,9 & 1,8 & 14,8 & 76.545 & $x$ \\
\hline & $\begin{array}{l}\mathrm{N}^{\circ} \text { de Quotas Tarifárias e Valores } \\
\text { Médios (Estados Unidos) }\end{array}$ & 18 & 58,6 & 7,5 & 91,4 & - & - \\
\hline \multirow{3}{*}{ CANADÁ } & Carne de aves & $2 M X$ & 99,8 & 4,7 & 203,5 & 45.432 & $x$ \\
\hline & Carne bovina & LD & 99,2 & 0 & 26,5 & 76.409 & $x$ \\
\hline & $\begin{array}{l}N^{\circ} \text { de Quotas Tarifárias e Valores } \\
\text { Médios (Canadá) }\end{array}$ & 3 & 99,5 & 2,4 & 115 & - & - \\
\hline \multirow{5}{*}{ MÉXICO } & Açúcar bruto & AT & 82 & 50 & 125,8 & 183.800 & - \\
\hline & Café - grão & AT & 16 & 50 & 72 & 20.800 & $x$ \\
\hline & Carne de aves & AT & 100 & 50 & 225,2 & 40.543 & - \\
\hline & Milho & AT & 100 & 50 & 194 & 2.501 .000 & - \\
\hline & $\begin{array}{l}N^{0} \text { de Quotas Tarifárias e Valores } \\
\text { Médios (México) }\end{array}$ & 4 & 74,5 & 50 & 154,3 & - & - \\
\hline TOTAL & $\begin{array}{l}N^{\circ} \text { de Quotas Tarifárias e Valores } \\
\text { Médios (Bloco) }\end{array}$ & 25 & 70,7 & 20,8 & 116,3 & - & - \\
\hline
\end{tabular}

Fonte: dados de pesquisa, WTO (2002), United States (2003) e Brasil (2003)

Os níveis tarifários praticados são baixos para tarifa intraquota e muito altos para tarifa extraquota para carne de aves, o que torna a importação extraquota inviável e relativamente baixa para as carnes bovinas.

Os métodos adotados são o mix de métodos e as licenças sobre demanda, o que denota a forte tendência de controle de importação por parte 
do governo canadense para esses produtos, conforme explicitado na parte teórica do presente trabalho.

No caso da carne de aves, maior acesso deve ser alcançado pelo aumento das quotas, uma vez que a importação extraquota torna-se inviável com a adoção de uma tarifa de $203,5 \%$. No caso das carnes, a tarifa extraquota da ordem de $26,5 \%$ é relativamente pequena. O não-preenchimento nesse caso deve estar vinculado a outros fatores que não os níveis tarifários impostos, ou seja, no método de administração utilizado, ou ainda nos padrões inatingíveis de qualidade e sanidade dos alimentos.

Os Estados Unidos impõem 18 quotas tarifárias aos produtos agroindustriais brasileiros escolhidos, as quais não possuem homogeneidade quanto ao preenchimento médio das quotas. Verifica-se na tabela 13 que somente o açúcar bruto tem nível de preenchimento alto, entretanto não chega a ser completado. Todos os demais produtos possuem taxas de preenchimento entre $40 \%$ e $60 \%$.

Destaque seja dado ao algodão, por impor sete das 18 quotas tarifárias dos EUA e possuir o menor índice de preenchimento do país, 14,9\%. Ressalta-se ainda que esse produto recebe ainda forte assistência do governo por meio de subsídios e apoio doméstico à produção.

Os Estados Unidos, como um dos principais mercados mundiais, embora estabeleçam um volume para as quotas em valor comparativamente muito superior aos demais países analisados, poderiam aumentar o volume de suas quotas dado o tamanho de seu mercado.

Os níveis tarifários praticados são inferiores às médias globais de cada produto, o que soa paradoxal diante da teoria. Tarifas reduzidas deveriam significar elevadas taxas de preenchimento de quotas, o que não se verifica nesse caso. 
Todas as quotas são administradas sob o método first come,first served, embora, conforme aponta Skully (2001a), o açúcar bruto seja administrado sob base histórica. Isso denota mais uma vez a falta de transparência do sistema de quotas tarifárias. Oficialmente esse produto é administrado como first come, first served, na prática sofre alocação histórica, de tal sorte que grande parte da quota do açúcar bruto é disponibilizada discricionariamente a países favorecidos por acordos preferenciais ou unilaterais americanos.

O México impõe quatro quotas tarifárias aos produtos brasileiros escolhidos, todos administrados por tarifa aplicada, conforme apontado na tabela 13. As quotas para carne de aves e milho têm preenchimento de $100 \%$ e volumes de quota expressivos, de 40.543 e 2.501 .000 toneladas respectivamente.

O café em grão possui taxa de preenchimento muito pequena, em torno de $16 \%$, e uma quota de 20.800 sacas ou aproximadamente 1.248 toneladas do produto. Cabe ressaltar que o México tem grande capacidade de suprir qualquer demanda de café de seu mercado doméstico.

Por fim, o açúcar bruto possui taxa de preenchimento relativamente alta (82\%) e volume de quota de 183.800 toneladas.

O Brasil consegue exportar em todos os casos para Estados Unidos e Canadá. Vale lembrar que esses países exigem um padrão alto de qualidade e sanidade de alimentos, o que dificulta o comércio brasileiro, além de subsidiarem seus produtores, o que exerce forte influência sobre a oferta doméstica de produtos agroindustriais, diminuindo a demanda por importação.

O México somente importa café em grão brasileiro. Para os demais produtos sujeitos a quotas tarifárias, não foram verificadas exportações brasileiras no triênio 2000-2002. Isso se deve provavelmente à participação 
mexicana no NAFTA, o qual favorece as exportações americanas e canadenses por meio de tarifas e quotas preferenciais. Outro fator que pode explicar o resultado encontrado é a proximidade do México com os mercados produtores caribenhos e centro-americanos.

\subsection{Países da comunidade andina}

Colômbia, Equador e Venezuela são os países sul-americanos analisados neste trabalho. A proximidade com o Brasil deveria ser refletida no comércio entre essas nações, entretanto percebe-se um certo distanciamento comercial entre elas. O interesse brasileiro reside, portanto, em procurar expandir suas exportações para esses mercados, fato que pode ser verificado pela recente aproximação de Venezuela e Brasil, e do acordo entre Mercosul e Comunidade Andina - este ainda em processo de negociação.

Os três países analisados também farão parte da área de Livre Comércio das Américas. Assim, a percepção da sensibilidade de seus produtos agroindustriais pode ser importante para a formulação da posição brasileira nessa negociação. Daí a importância do estudo da influência das quotas tarifárias adotadas por esses países sobre os produtos agroindustriais exportados pelo Brasil.

A Colômbia impõe 20 quotas tarifárias, todas com alto nível de preenchimento, entretanto com elevado nível tarifário. O preenchimento das quotas é completo para farelo e óleo de soja, outros açúcares, suco de laranja, milho e algodão. Os métodos de administração alternam-se entre a tarifa aplicada e licença sobre demanda.

Cabe ressaltar a pequena taxa de preenchimento para o açúcar bruto, da ordem de $35,1 \%$, este resultado deve-se, sobretudo, a sua tarifa de $98,5 \%$. Essa tarifa é maior que a média global do produto, porém não se pode descartar outros motivos ligados, por exemplo, à oferta interna do produto 
suficiente para impedir importação. O mesmo ocorre com a carne bovina. Nesses casos, um estudo aprofundado sobre os setores na Colômbia é que pode trazer uma explicação para esse comportamento.

O Equador, como ilustrado na tabela 14, é um caso peculiar. Impõe sete quotas tarifárias, todas com baixo nível de preenchimento da quota e todas administradas por meio de alocação histórica.

Percebe-se que as tarifas são reduzidas quando comparadas às médias globais dos produtos e que o volume da quota possui um valor razoável.

Nesse caso, não se verifica a prerrogativa de que tarifas reduzidas resultariam em altos níveis de preenchimento. Esse comportamento exige um estudo aprofundado sobre a economia equatoriana.

A Venezuela impõe 13 quotas tarifárias aos produtos brasileiros escolhidos. Apenas uma delas atinge preenchimento completo, o açúcar bruto.

Segundo a tabela 14 , via de regra, as taxas de preenchimento variam de médio a alto, mostra tarifas intraquota estabelecidas uniformemente em $40 \%$ e tarifas extraquota pouco superior à média global destacada na tabela 11. 
Tabela 14. Informações sobre produtos agroindustriais de interesse ao Brasil sujeitos a quotas tarifárias em países sul-americanos.

\begin{tabular}{|c|c|c|c|c|c|c|c|}
\hline País & Produto & $\begin{array}{l}\text { Método de } \\
\text { Administração }\end{array}$ & $\begin{array}{l}\text { Taxa de } \\
\text { Preenchimento }\end{array}$ & $\begin{array}{c}\text { Tarifa } \\
\text { Intra-Quota }\end{array}$ & $\begin{array}{c}\text { Tarifa } \\
\text { Extra-Quota }\end{array}$ & Quota (Ton) & $\begin{array}{c}\text { Ocorrência de } \\
\text { Exportações } \\
\text { Brasileiras } \\
\end{array}$ \\
\hline \multirow{11}{*}{ COLÔMBIA } & Soja - grão & LD & 98,0 & 125,0 & 125,0 & 145.704 & $x$ \\
\hline & Soja - farelo & AT & 100,0 & 97,0 & 97,0 & 3.653 & - \\
\hline & Soja - óleo & LD & 100,0 & 75,0 & 75,0 & 48.677 & $x$ \\
\hline & Açúcar bruto & 2AT & 35,1 & 98,5 & 117,0 & 57.364 & - \\
\hline & Açúcar - outros & 2AT & 100,0 & 115,0 & 115,0 & 3.299 & $x$ \\
\hline & Carne de aves & 2LD - $10 T$ & 80,3 & 134,0 & 177,0 & 10.568 & - \\
\hline & Carne bovina & उAT & 53,0 & 98,7 & 108,0 & 28.977 & $x$ \\
\hline & Suco de laranja & AT & 100,0 & 137,0 & 137,0 & 462 & $x$ \\
\hline & Carne suína & $2 \mathrm{AT}$ & 99,1 & 94,0 & 108,0 & 4.838 & - \\
\hline & Milho & 2LD & 100,0 & 274,0 & 194,0 & 41.843 & - \\
\hline & Algodão & $2 \mathrm{AT}$ & 100,0 & 89,5 & 99,0 & 2.886 & $x$ \\
\hline \multirow{6}{*}{ EQUADOR } & $\begin{array}{l}\mathrm{N}^{\circ} \text { de Quotas Tarifárias e Valores } \\
\text { Médios (Colômbia) }\end{array}$ & 20 & 87,8 & 121,6 & 122,9 & - & - \\
\hline & Soja - farelo & $\mathrm{HI}$ & $\mathrm{N}, \mathrm{D}$, & 25,0 & 38,7 & 17.000 & - \\
\hline & Açúcar bruto & $3 \mathrm{HI}$ & 0,0 & 35,0 & 45,0 & 1.800 & - \\
\hline & Carne de aves & $2 \mathrm{HI}$ & 28,3 & 27,5 & 65,3 & 2.750 & - \\
\hline & Milho & $\mathrm{HI}$ & 40,0 & 30,0 & 40,0 & 19.678 & - \\
\hline & $\begin{array}{l}\mathrm{N}^{\circ} \text { de Quotas Tarifárias e Valores } \\
\text { Médios (Equador) }\end{array}$ & 7 & 22,8 & 29,4 & 47,3 & - & - \\
\hline \multirow{8}{*}{ VENEZUELA } & Soja - grão & $\mathrm{HI}$ & 93,7 & 40,0 & 117,0 & 168.963 & $x$ \\
\hline & Soja - farelo & $\mathrm{HI}$ & 70,5 & 40,0 & 97,0 & 696.880 & $x$ \\
\hline & Soja - óleo & $\mathrm{HI}$ & 88,6 & 40,0 & 75,0 & 130.040 & - \\
\hline & Açúcar bruto & $\mathrm{HI}$ & 100,0 & 40,0 & 105,0 & 132.013 & - \\
\hline & Açúcar - outros & 2AT & 62,5 & 40,0 & 109,0 & 18.603 & $x$ \\
\hline & Carne de aves & AT & 4,2 & 40,0 & 135,0 & 3.426 & - \\
\hline & Carne suína & AT & 63,7 & 40,0 & 48,0 & 877 & $x$ \\
\hline & Milho & 4AT-1HI & 81,4 & 30,0 & 122,0 & 636.439 & - \\
\hline & $\begin{array}{l}N^{\circ} \text { de Quotas Tarifárias e Valores } \\
\text { Médios (Venezuela) }\end{array}$ & 13 & 70,6 & 38,8 & 101,0 & - & - \\
\hline TOTAL & $\begin{array}{l}N^{\circ} \text { de Quotas Tarifárias e Valores } \\
\text { Médios (Bloco) }\end{array}$ & 25 & 75,3 & 76,4 & 116,2 & - & - \\
\hline
\end{tabular}

Fonte: dados de pesquisa, WTO (2002); United States (2003) e Brasil (2003)

Não possui um padrão quanto ao volume das quotas, que varia entre pouco e bastante expressivo. Nesse sentido, avaliações mais conclusivas necessitariam de um estudo produto a produto mais detalhado.

A performance exportadora brasileira sujeita a quotas tarifárias nessas nações é decepcionante. O Brasil não conseguiu exportar farelo de soja, açúcar bruto, carne de aves e suína e milho para a Colômbia. Ressalte-se 
que esse país possui nível de preenchimento elevado em quase todas as quotas tarifárias. O Equador não importou do Brasil nenhum produto sujeito a quotas tarifárias e a Venezuela não importou do Brasil óleo de soja, açúcar bruto, carne de aves e milho.

Cabe destacar que o Brasil é um grande produtor desses produtos e os oferece internacionalmente a um preço bastante competitivo. Nesse sentido, a baixa performance exportadora brasileira sujeita a quotas tarifárias para os países analisados pode estar diretamente ligada à utilização do sistema de quotas tarifárias. Assim, as negociações da Alca e acordos birregionais (Mercosul-Comunidade Andina) podem vir a reverter esse quadro. Uma vez que Colômbia, Equador e Venezuela importam os produtos relacionados, a restrição ao Brasil não se encontra na demanda reduzida; portanto, a inexistência de exportação brasileira deve estar ligada ao processo de distribuição de licenças de importação por parte desses países. As negociações comerciais, nesse caso, são os fóruns ideais para alterar esse comportamento, ou seja, garantir quota para o Brasil.

\subsection{Países centro-americanos e do Caribe}

Os países centro-americanos e do Caribe, por se tratar, em geral, de economias pequenas, sofrem grande influência de economias maiores, como a norte-americana. $\mathrm{O}$ acesso preferencial aos grandes mercados mundiais tem grande importância na economia dessas nações. Essa característica se reflete no seu protecionismo comercial e na sua posição diante das negociações internacionais de comércio.

No que tange às quotas tarifárias, Barbados impõe nove quotas tarifárias, todas com elevado nível de preenchimento, sendo que em quatro delas (açúcar bruto, suco de laranja, carne suína e milho) o preenchimento é completo, conforme tabela 15. 
Tabela 15. Informações sobre produtos agroindustriais de interesse ao Brasil sujeitos a quotas tarifárias em países centro-americanos e do Caribe.

\begin{tabular}{|c|c|c|c|c|c|c|c|}
\hline País & Produto & $\begin{array}{c}\text { Método de } \\
\text { Administração }\end{array}$ & $\begin{array}{c}\text { Taxa de } \\
\text { Preenchimento }\end{array}$ & $\begin{array}{c}\text { Tarifa } \\
\text { Intra-Quota }\end{array}$ & $\begin{array}{c}\text { Tarifa } \\
\text { Extra-Quota }\end{array}$ & Quota (Ton) & $\begin{array}{l}\text { Ocorrência de } \\
\text { Exportações } \\
\text { Brasileiras }\end{array}$ \\
\hline \multirow{9}{*}{ BARBADOS } & Açúcar bruto & AT & 100,0 & 122,0 & 122,0 & 2 & - \\
\hline & Açúcar - outros & AT & 97,3 & 141,0 & 141,0 & 112 & $x$ \\
\hline & Carne de aves & AT & 99,0 & 184,0 & 184,0 & 406 & - \\
\hline & Suco de laranja & $2 \mathrm{AT}$ & 100,0 & 141,0 & 141,0 & 120 & - \\
\hline & Carne suína & AT & 100,0 & 184,0 & 184,0 & 59 & - \\
\hline & Melão & AT & 85,3 & 147,0 & 147,0 & 3 & - \\
\hline & Mamão & AT & 22,8 & 103,0 & 147,0 & 28 & - \\
\hline & Milho & AT & 100,0 & 160,0 & 160,0 & 13 & - \\
\hline & $\begin{array}{l}\mathrm{N}^{\circ} \text { de Quotas Tarifárias e Valores } \\
\text { Médios (Barbados) }\end{array}$ & 9 & 88,1 & 147,8 & 153,3 & - & - \\
\hline \multirow{11}{*}{ GUATEMALA } & Soja - grão & AT & 37,2 & 45,0 & 65,5 & 1.650 & - \\
\hline & Soja - farelo & AT & 75,2 & 10,0 & 40,0 & 33.820 & - \\
\hline & Soja - óleo & AT & 100,0 & 10,0 & 232,0 & 1.000 & $x$ \\
\hline & Açúcar - outros & LD & 0,0 & 45,0 & 160,0 & 14.367 & $x$ \\
\hline & Carne de aves & LD & 80,3 & 45,0 & 257,0 & 7.000 & - \\
\hline & Carne bovina & LD & 72,0 & $N, D$ & $\mathrm{~N}, \mathrm{D}$ & 1.595 & - \\
\hline & Tabaco & AT & 100,0 & 31,7 & 90,0 & 96 & $x$ \\
\hline & Carne suína & LD & 97,0 & 45,0 & 59,0 & 500 & - \\
\hline & Uva & AT & $\mathrm{N}, \mathrm{D}$, & 30,0 & 82,5 & 25 & - \\
\hline & Milho & LD & 100,0 & 30,0 & 68,0 & 88.670 & - \\
\hline & $\begin{array}{l}N^{\circ} \text { de Quotas Tarifárias e Valores } \\
\text { Médios (Guatemala) }\end{array}$ & 10 & 73,5 & 32,4 & 117,1 & - & - \\
\hline \multirow{4}{*}{ PANAMÁ } & Carne de aves & AT & 0,0 & 15,0 & 260,0 & 756 & - \\
\hline & Carne suína & AT & 100,0 & 15,0 & 69,0 & 880 & - \\
\hline & Milho & AT & 100,0 & 15,0 & 40,0 & 150.000 & - \\
\hline & $\begin{array}{l}\mathrm{N}^{\circ} \text { de Quotas Tarifárias e Valores } \\
\text { Médios (Panamá) }\end{array}$ & 3 & 66,7 & 15,0 & 123,0 & - & - \\
\hline TOTAL & $\begin{array}{l}N^{\circ} \text { de Quotas Tarifárias e Valores } \\
\text { Médios (Bloco) }\end{array}$ & 22 & 78,3 & 75,9 & 132,5 & - & - \\
\hline
\end{tabular}

Fonte: dados de pesquisa, WTO (2002); United States (2003) e Brasil (2003)

Utiliza para todos os produtos o método da tarifa aplicada e consolida uma única tarifa sobre as importações, ou seja, não diferencia a tarifa intraquota da extraquota. Entretanto, os níveis tarifários cobrados são muito superiores à média global por produto constante da tabela 11.

A elevada taxa de preenchimento está vinculada não à imposição de tarifas reduzidas, mas aos pequenos volumes das quotas. Dessa maneira, por ser um típico caso de método de tarifa aplicada, a redução dos níveis tarifários 
intraquota é que aumentará o acesso dos produtos, uma vez que a quota não é exercida.

Vale ressaltar que o tamanho pequeno dessa economia a torna importadora líquida de alimentos, principalmente daqueles mais elaborados. Contudo maior acesso a esse mercado seria muito pequeno às aspirações brasileiras.

A Guatemala, segundo tabela 15, impõe dez quotas tarifárias, das quais três são completamente preenchidas, a saber: óleo de soja, tabaco e milho.

Destaque seja dado à soja em grão, com preenchimento na ordem de $37,2 \%$, o que representa cerca de 613,8 toneladas apenas, uma quantidade bastante reduzida de importação para um volume de quota pequeno, e tarifas intraquota menores que a média global do produto.

Outro produto a ser destacado é o açúcar - outros, que obteve preenchimento igual a zero. Possui uma quota pequena e a tarifa intraquota é relativamente pequena, o que não corrobora com a teoria. Esse fato deve estar relacionado às condições internas de oferta do produto ou vinculado à forma de administração.

Os métodos utilizados são a tarifa aplicada e as licenças sobre demanda, os quais não possuem homogeneidade quanto ao comportamento, evitando, assim, a obtenção de conclusões sobre a sua correlação perante o nível de preenchimento das quotas.

O Panamá, conforme pode ser visto na tabela 15, tem três quotas tarifárias que afetam diretamente os produtos de maior interesse ao Brasil. Em duas delas o preenchimento é de $100 \%$. Carne de aves possui preenchimento zero; nesse caso razões internas devem explicar esse comportamento. 
Via de regra, as tarifas intraquota são inferiores às médias globais e as tarifas extraquota são bastante elevadas. Verifica-se também que os volumes das quotas são pequenos, o que facilita o seu preenchimento.

A performance exportadora brasileira de produtos agroindustriais sujeitos a quotas tarifárias para Barbados, Guatemala e Panamá é decepcionante. O Brasil restringe-se a exportar açúcar, óleo de soja e tabaco para a Guatemala, açúcar para Barbados e não possui nenhum acesso ao mercado panamenho.

\subsection{Países asiáticos}

Os países asiáticos tornaram-se nas últimas décadas grandes mercados consumidores de gêneros alimentícios, chamando a atenção dos grandes players mundiais. Nesse sentido, a redução do seu protecionismo pode representar grandes ganhos às balanças comerciais de nações exportadoras de produtos agroindustriais. As quotas tarifárias, portanto, tornam-se um importante empecilho ao maior acesso a esses mercados.

A Coréia do Sul impõe nove quotas tarifárias sobre aqueles produtos de maior interesse brasileiro. Em todos os casos, encontra-se alta taxa de preenchimento das quotas. Em geral as tarifas intraquota são mais baixas que a média global dos produtos, comportamento que é acompanhado pelas tarifas extraquota, conforme descrito na tabela 16. 
Tabela 16. Informações sobre produtos agroindustriais de interesse ao Brasil sujeitos a quotas tarifárias em países asiáticos.

\begin{tabular}{|c|c|c|c|c|c|c|c|}
\hline País & Produto & $\begin{array}{c}\text { Método de } \\
\text { Administração }\end{array}$ & $\begin{array}{c}\text { Taxa de } \\
\text { Preenchimento }\end{array}$ & $\begin{array}{c}\text { Tarifa } \\
\text { Intra-Quota }\end{array}$ & $\begin{array}{c}\text { Tarifa } \\
\text { Extra-Quota }\end{array}$ & Quota (Ton) & $\begin{array}{c}\text { Ocorrência de } \\
\text { Exportações } \\
\text { Brasileiras } \\
\end{array}$ \\
\hline \multirow{9}{*}{$\begin{array}{l}\text { CORÉIA DO } \\
\text { SUL }\end{array}$} & Soja - grão & $M X$ & 100,0 & 5,0 & 487,0 & 1.032 .152 & $x$ \\
\hline & Álcool etílico & $\mathrm{HI}$ & 99,5 & 30,0 & 90,0 & 10334 (em KL) & $x$ \\
\hline & Carne de aves & $A U$ & 90,0 & 20,0 & $\mathrm{~N}, \mathrm{D}$, & 6.500 & $x$ \\
\hline & Carne bovina & $M X$ & 84,5 & 41,6 & 40,0 & 225.000 & $x$ \\
\hline & Suco de laranja & $\mathrm{HI}$ & 91,3 & 50,0 & 54,0 & 30.000 & $x$ \\
\hline & Carne suína & $A U$ & 100,0 & 25,0 & 25,0 & 18.275 & $x$ \\
\hline & Laranja & $M X$ & 97,7 & 50,0 & 50,0 & 57.017 & - \\
\hline & Milho & LD-HI & 100,0 & 2,5 & 316,0 & 6.102 .100 & $x$ \\
\hline & $\begin{array}{l}\mathrm{N}^{\circ} \text { de Quotas Tarifárias e Valores } \\
\text { Médios (Coréia do Sul) }\end{array}$ & 9 & 95,4 & 28,0 & 151,7 & - & - \\
\hline \multirow{7}{*}{ FILIPINAS } & Açúcar bruto & $\mathrm{HI}$ & 97,0 & 50,0 & 50,0 & 64.050 & $x$ \\
\hline & Café - grão & $\mathrm{HI}$ & 80,2 & 40,0 & 40,0 & 6 & - \\
\hline & Carne de aves & $2 \mathrm{HI}$ & 10,5 & 40,0 & 39,6 & 23.490 & $x$ \\
\hline & Carne bovina & AT & 40,5 & 30,0 & 37,5 & 5.570 & $x$ \\
\hline & Carne suína & $\mathrm{HI}$ & 12,0 & 30,0 & 40,0 & 54.210 & $x$ \\
\hline & Milho & $\mathrm{HI}$ & 99,7 & 35,0 & 50,0 & 216.940 & - \\
\hline & $\begin{array}{l}\mathrm{N}^{\circ} \text { de Quotas Tarifárias e Valores } \\
\text { Médios (Filipinas) }\end{array}$ & 7 & 56,7 & 37,5 & 42,9 & - & - \\
\hline \multirow{6}{*}{ MALÁSIA } & Açúcar bruto & LD & 6,5 & 22,5 & 35,6 & 29.600 & $x$ \\
\hline & Café - grão & LD & 100,0 & 5,0 & 69,0 & 9.873 & $x$ \\
\hline & Carne de aves & 6LD & 65,9 & 50,3 & 56,3 & 10.828 & $x$ \\
\hline & Tabaco & $\mathrm{HI}$ & 100,0 & 879,0 & 2627,1 & 2.500 & $x$ \\
\hline & Carne suína & LD & 0,0 & 40,0 & 138,6 & 1.727 & - \\
\hline & $\begin{array}{l}\mathrm{N}^{\circ} \text { de Quotas Tarifárias e Valores } \\
\text { Médios (Malásia) }\end{array}$ & 10 & 54,5 & 199,4 & 585,3 & - & - \\
\hline \multirow{9}{*}{ TAILÂNDIA } & Soja - grão & GP & 100,0 & 20,0 & 80,0 & 10.922 & $x$ \\
\hline & Soja - farelo & GP & 100,0 & 20,0 & 133,0 & 230.559 & $x$ \\
\hline & Soja - óleo & GP & 27,8 & 20,0 & 146,0 & 2.281 & - \\
\hline & Açúcar bruto & LD & 0,0 & 65,0 & 94,0 & 13.720 & - \\
\hline & Café - grão & LD & 41,0 & 30,0 & 90,0 & 5 & $x$ \\
\hline & Café solúvel & LD & 44,8 & 40,0 & 49,0 & 134 & $x$ \\
\hline & Tabaco & $\mathrm{AE}$ & 90,5 & 60,0 & 72,0 & 6.435 & $x$ \\
\hline & Milho & $\mathrm{AE}$ & 98,6 & 20,0 & 73,0 & 54.700 & - \\
\hline & $\begin{array}{l}\mathrm{N}^{\circ} \text { de Quotas Tarifárias e Valores } \\
\text { Médios (Tailândia) }\end{array}$ & 8 & 62,8 & 34,4 & 92,1 & - & - \\
\hline TOTAL & $\begin{array}{l}\mathrm{N}^{\circ} \text { de Quotas Tarifárias e Valores } \\
\text { Médios (Bloco) }\end{array}$ & 25 & 69,6 & 63,7 & 191,6 & - & - \\
\hline
\end{tabular}

Fonte: dados de pesquisa, WTO (2002); United States (2003) e Brasil (2003)

Destaque seja dado ao milho e à soja; nesses casos a tarifa extraquota é muito elevada, e, portanto, extremamente proibitiva - em torno de $316 \%$ e $487 \%$, respectivamente. Entretanto o preenchimento é completo e a tarifa intraquota é reduzida, além de volumes de quota bastante expressivos (6,1 milhões de toneladas e 1 milhão de toneladas, respectivamente). 
A Coréia do Sul não possui um padrão para a adoção de seus métodos de administração, os quais variam entre todos os tipos de métodos. $\mathrm{O}$ único que não é aplicado é o da tarifa aplicada.

As quotas tarifárias adotadas por esse país ilustram novamente o fato de tarifas intraquota reduzidas se refletirem em alto nível de preenchimento das quotas.

As Filipinas impõem sete quotas tarifárias que variam diametralmente quanto ao nível de preenchimento da quota. Em nenhum dos casos, verifica-se total preenchimento, de acordo com a tabela 16.

Um caso pitoresco é a tarifa intraquota para a carne de aves ser superior à extraquota. Nesse caso medidas de "advalorização" podem ter provocado esse fenômeno, e, por isso então, o baixo índice de preenchimento da quota; A discrepância entre as tarifas intraquota e extraquota pode estar relacionada a problemas de digitação e publicação dos órgãos oficiais filipinos.

A carne suína também possui preenchimento reduzido, mesmo tendo tarifas inferiores à média global e volume de quota que não determinaria tal comportamento. Nesse caso, o método de administração e condições internas de oferta podem ter influenciado o resultado.

Em geral, suas tarifas são inferiores às médias globais e administradas por meio da alocação histórica.

A Malásia impõe dez quotas tarifárias, das quais duas com preenchimento de 100\% (café e tabaco). O café é administrado por licenças sobre demanda, enquanto o tabaco é administrado por alocação histórica, segundo a tabela 16.

Em geral, as tarifas da Malásia, tanto as intraquota quanto as extraquota, não são muito elevadas. Contudo, um caso curioso é o do tabaco. 
Esse produto tem tarifa intraquota no valor de $870 \%$, tarifa extraquota no valor de $2.627,1 \%$ e volume de importação intraquota restrito a 2.500 toneladas por ano. Esse país deve ter uma população tabagista muito pequena.

A Tailândia impõe oito quotas tarifárias sobre os produtos brasileiros escolhidos, segundo a tabela 16 deste trabalho. Duas delas atingem preenchimento completo (soja em grão e farelo de soja), enquanto o açúcar bruto tem preenchimento zero.

Em geral, as tarifas intraquota são baixas (inferiores às médias globais) e não há um comportamento-padrão para as tarifas extraquota, podendo estas ser altas ou baixas, dependendo do produto.

Outra característica desse país é o volume baixo da quota. Isso deveria facilitar o preenchimento, fato que ocorre somente em dois casos. Esse comportamento deve ser explicado por questões internas de oferta e demanda.

Verifica-se que os dois casos de preenchimento completo são administrados pelo método grupo de produtores, o que corrobora com a literatura. Os grupos de produtores determinam elevados índices de preenchimento.

A exportação brasileira dos produtos agroindustriais sujeitos a quotas tarifárias para países asiáticos representa uma grande oportunidade perdida. $\mathrm{O}$ Brasil não exportou para essas nações laranja de mesa, café em grão, milho, carne suína, açúcar bruto e óleo de soja, artigos em que é muito competitivo internacionalmente. Nesse caso, o país deve procurar maior acesso, principalmente, garantindo uma quota para seus produtos.

\subsection{Países do leste europeu}

O recente processo de negociação de incorporação dos países do Leste Europeu à União Européia é de grande interesse para as autoridades 
brasileiras. As decisões sobre esse acordo se refletem nas posições, não só de brasileiros, mas de todos os grandes players do comércio internacional. A incorporação das nações do Leste Europeu à União Européia pode trazer mais restrições a acesso a mercado de produtos brasileiros, entre as quais a intensificação do uso de quotas tarifárias.

A Eslovênia impõe 13 quotas tarifárias sobre os produtos de maior interesse ao Brasil, sendo oito delas sobre carne bovina, conforme a tabela 17. Uma peculiaridade reside no fato de as tarifas intra e extraquota serem inferiores à média global; nesse caso se esperaria uma taxa de preenchimento alta, fato que não ocorre. 
Tabela 17. Informações sobre produtos agroindustriais de interesse ao Brasil sujeitos a quotas tarifárias em países do leste europeu.

\begin{tabular}{|c|c|c|c|c|c|c|c|}
\hline País & Produto & $\begin{array}{c}\text { Método de } \\
\text { Administração }\end{array}$ & $\begin{array}{c}\text { Taxa de } \\
\text { Preenchimento }\end{array}$ & $\begin{array}{c}\text { Tarifa } \\
\text { Intra-Quota }\end{array}$ & $\begin{array}{c}\text { Tarifa } \\
\text { Extra-Quota }\end{array}$ & Quota (Ton) & $\begin{array}{c}\text { Ocorrência de } \\
\text { Exportações } \\
\text { Brasileiras } \\
\end{array}$ \\
\hline \multirow{4}{*}{ ESLOVÊNIA } & Carne bovina & $8 \mathrm{LD}$ & 20,1 & 17,5 & 79,3 & 2.438 & - \\
\hline & Carne suína & 4LD & 41,7 & 18,1 & 52,9 & 2.431 & - \\
\hline & Milho & LD & 67,8 & 7,7 & 58,0 & 120.000 & - \\
\hline & $\begin{array}{l}N^{\circ} \text { de Quotas Tarifárias e Valores } \\
\text { Médios (Eslovênia) }\end{array}$ & 13 & 43,2 & 14,4 & 63,4 & - & - \\
\hline \multirow{13}{*}{ HUNGRIA } & Açúcar - outros & LD-AT & 60,3 & 45,0 & 45,6 & 2.912 & - \\
\hline & Café solúvel & LD & 33,8 & 60,0 & 51,2 & 2.146 & $x$ \\
\hline & Carne de aves & LD & 16,0 & 25,0 & 35,5 & 11.425 & - \\
\hline & Carne bovina & LD & 56,3 & 17,5 & 56,0 & 13.595 & - \\
\hline & Tabaco & LD & 41,0 & 47,0 & 50,8 & 6.528 & $x$ \\
\hline & Carne suína & 2LD & 78,6 & 17,5 & 45,0 & 19.909 & - \\
\hline & Melão & LD & 77,6 & 25,0 & 51,0 & 4.931 & - \\
\hline & Uva & LD & 34,6 & 40,0 & 48,0 & 3.016 & - \\
\hline & Banana & LD & 97,4 & 20,0 & 20,0 & 17.079 & - \\
\hline & Laranja & LD & 34,6 & 30,0 & 28,5 & 63.159 & - \\
\hline & Milho & LD & 4,5 & 3,0 & 26,0 & 222.935 & $x$ \\
\hline & Derivados de cacau & LD & 53,3 & 30,0 & 24,8 & 911 & - \\
\hline & $\begin{array}{l}\mathrm{N}^{\circ} \text { de Quotas Tarifárias e Valores } \\
\text { Médios (Hungria) }\end{array}$ & 14 & 49,0 & 30,0 & 40,2 & - & - \\
\hline \multirow{15}{*}{ POLÔNIA } & Soja - óleo & AT & $\mathrm{N}, \mathrm{D}$, & 40,0 & 51,0 & 50.000 & $x$ \\
\hline & Açúcar - outros & AT & $\mathrm{N}, \mathrm{D}$ & 67,3 & 147,8 & 7.800 & $x$ \\
\hline & Álcool etílico & LD & 3,0 & 105,0 & 268,0 & 87.974 & - \\
\hline & Café - grão & AT & $\mathrm{N}, \mathrm{D}$, & 30,0 & 19,0 & $\mathrm{~N}, \mathrm{D}$ & $x$ \\
\hline & Carne de aves & LD-AT & 74,1 & 30,0 & 40,0 & 21.000 & $x$ \\
\hline & Carne bovina & 2AT-1LD & 25,0 & 31,7 & 133,1 & 31.900 & $x$ \\
\hline & Tabaco & $\mathrm{MX}$ & 29,4 & 88,3 & 169,3 & 6.840 & $x$ \\
\hline & Carne suína & LD-AT & 73,3 & 25,0 & 58,7 & 53.120 & - \\
\hline & Melão & AT & $\mathrm{N}, \mathrm{D}$, & 15,0 & 19,0 & 2.000 & - \\
\hline & Uva & AT & $\mathrm{N}, \mathrm{D}$, & 25,0 & 20,5 & 2.000 & - \\
\hline & Banana & AT & $\mathrm{N}, \mathrm{D}$, & 20,0 & 51,0 & 33.000 & - \\
\hline & Laranja & AT & $\mathrm{N}, \mathrm{D}$ & 20,0 & 69,5 & 12.500 & - \\
\hline & Milho & AT & $\mathrm{N}, \mathrm{D}$ & 20,0 & 59,7 & 250.000 & $x$ \\
\hline & Derivados de cacau & AT & $\mathrm{N}, \mathrm{D}$ & 86,0 & 86,0 & 2.500 & $x$ \\
\hline & $\begin{array}{l}\mathrm{N}^{\circ} \text { de Quotas Tarifárias e Valores } \\
\text { Médios (Polônia) }\end{array}$ & 18 & 41,0 & 43,1 & 85,2 & - & - \\
\hline \multirow{6}{*}{$\begin{array}{l}\text { REPÚBLICA } \\
\text { ESLOVACA }\end{array}$} & Açúcar - outros & LD & 80,8 & 50,0 & 28,3 & 75 & - \\
\hline & Álcool etílico & $2 \mathrm{LD}$ & 33,3 & 63,0 & 66,5 & 5.410 & - \\
\hline & Carne de aves & LD & 42,1 & 24,0 & 21,9 & 3.620 & $x$ \\
\hline & Carne bovina & LD & 45,5 & 30,0 & 56,0 & 3.730 & - \\
\hline & Uva & LD & 16,3 & 28,0 & 39,2 & 4.015 & - \\
\hline & $\begin{array}{l}\mathrm{N}^{\circ} \text { de Quotas Tarifárias e Valores } \\
\text { Médios (República Eslovaca) }\end{array}$ & 6 & 43,6 & 39,0 & 42,4 & - & - \\
\hline \multirow{7}{*}{$\begin{array}{l}\text { REPÚBLICA } \\
\text { TCHECA }\end{array}$} & Açúcar - outros & FC & 90,8 & 50,0 & 60,0 & 1.422 & - \\
\hline & Álcool etílico & $2 \mathrm{FC}$ & 53,3 & 63,0 & 66,5 & 152.708 & - \\
\hline & Carne de aves & FC & 94,6 & 24,0 & 43,0 & 3.471 & $x$ \\
\hline & Carne bovina & FC & 40,0 & 30,0 & 56,0 & 11.125 & - \\
\hline & Carne suína & FC & 18,3 & 27,5 & 37,3 & 24.720 & - \\
\hline & Uva & $\mathrm{FC}$ & 8,8 & 28,0 & 85,0 & 3.930 & - \\
\hline & $\begin{array}{l}\mathrm{N}^{\circ} \text { de Quotas Tarifárias e Valores } \\
\text { Médios (República Tcheca) }\end{array}$ & 7 & 51,0 & 37,1 & 58,0 & - & - \\
\hline TOTAL & $\begin{array}{l}\mathrm{N}^{\circ} \text { de Quotas Tarifárias e Valores } \\
\text { Médios (Bloco) }\end{array}$ & 58 & 46,7 & 35,6 & 60,6 & - & - \\
\hline
\end{tabular}

Fonte: dados de pesquisa, WTO (2002); United States (2003) e Brasil (2003) 
Outro fator que não segue o esperado, segundo aspectos teóricos, é o fato de o volume da quota ser reduzido, ou seja, de fácil preenchimento. Logo, estudo sobre essa economia também pode referenciar as tomadas de decisões quanto ao acesso a mercados. Outro fator a ser destacado é que a totalidade dessas quotas é administrada por licenças sobre demanda, o que provavelmente determina seu comportamento.

As 14 quotas tarifárias impostas pela Hungria, como pode ser verificado na tabela 17, possuem índice de preenchimento da quota elevado, embora suas tarifas, em geral, sejam inferiores às médias globais.

Os volumes das quotas não são muito expressivos (embora se deva considerar o tamanho do mercado consumidor e a renda per capita húngara), ou seja, para que haja informações mais precisas sobre a Hungria, bem como de todo o Leste Europeu, fazem-se necessários estudos aprofundados a respeito dessas economias e de sua atuação comercial.

O método mais comum são as licenças sobre demanda, o que pode exercer influência sobre o nível de preenchimento apontado.

São 18 as quotas tarifárias impostas pela Polônia aos produtos de maior interesse ao Brasil, conforme a tabela 17. A Polônia deixou de publicar uma série de informações quanto ao preenchimento das quotas, que, em geral, têm valores reduzidos.

Os métodos empregados variam entre a tarifa aplicada, licenças sobre demanda e mix de métodos. Não há um padrão regular na aplicação das tarifas, seja a intraquota, seja a extraquota, de forma que algumas são pequenas em relação à média global, enquanto outras são altas.

Os volumes das quotas são também, em geral, pequenos. 
Destaque seja dado ao fato de que, quando as tarifas são pequenas, há maior nível de preenchimento das quotas.

A República Eslovaca impõe seis quotas tarifárias àqueles produtos escolhidos para análise neste trabalho. Seu preenchimento é mediano, ou seja, fica, em média, em torno do $50 \%$. As tarifas aplicadas, tanto intra quanto extraquota, são inferiores às médias globais. Volumes estipulados como quota são pequenos e administrados por licença sobre demanda.

A República Checa estabeleceu sete quotas tarifárias contra os produtos de maior interesse ao Brasil. A tabela 17 mostra que todas são administradas pelo método first come, first served. Não existe para esse país um comportamento-padrão quanto ao preenchimento das quotas. Destaque seja dado ao açúcar e às uvas, de comportamento diametralmente oposto.

Via de regra, as tarifas intra e extraquotas são inferiores às médias globais e os volumes das quotas são pequenos. Nesse caso, condições internas de oferta devem explicar o baixo nível de importação intraquota.

A participação brasileira no Leste Europeu deixa muito a desejar. Não consegue exportar nada sujeito à quota tarifária para a Eslovênia e apenas carne de aves para a República Eslovaca e República Checa. A Hungria abre um pouco mais seu mercado a produtos brasileiros. Esse mercado é abastecido por café solúvel, tabaco e milho do Brasil. Caso à parte é a Polônia. Essa nação oferece, em parte de suas quotas tarifárias, acesso aos produtos brasileiros. Esse comportamento pode ser influenciado, primeiramente, por esses países serem produtores rurais e pela proximidade da União Européia, entretanto, isso não redime as autoridades brasileiras de procurarem acessar esses mercados, garantindo participação maior nas suas importações. 


\subsection{Noruega e Islândia}

Os países do norte europeu, aqui representados por Noruega e Islândia, poderiam ser enquadrados juntamente com a União Européia ou as nações do Leste Europeu, contudo, por causa das características particulares desses dois países, serão tratados separadamente.

A Islândia, entre as suas 12 quotas tarifárias impostas aos produtos agroindustriais de maior interesse ao Brasil, não possui homogeneidade quanto ao preenchimento das quotas, conforme ilustrado na tabela 18. Por exemplo, óleo de soja, carne suína e derivados de cacau completam totalmente suas quotas, enquanto carne de aves e carne bovina perfazem $31,6 \%$ e $8,2 \%$, respectivamente.

Verifica-se em geral que as menores tarifas intraquota praticadas referem-se às quotas com preenchimento total. Chama a atenção que a quota para carne bovina é extremamente pequena (apenas 95 toneladas), o que indica que existem condições internas de abastecimento e que o método de leilão, como já foi apresentado pela literatura, vincula-se diretamente ao baixo nível de preenchimento da quota.

A Noruega impõe apenas 19 quotas tarifárias aos produtos agroindustriais brasileiros escolhidos, conforme a tabela 18. Cabe salientar que esse país consolidou 232 quotas tarifárias. 
Tabela 18. Informações sobre produtos agroindustriais de interesse ao Brasil sujeitos a quotas tarifárias na Noruega e Islândia.

\begin{tabular}{|c|c|c|c|c|c|c|c|}
\hline País & Produto & $\begin{array}{l}\text { Método de } \\
\text { Administração }\end{array}$ & $\begin{array}{c}\text { Taxa de } \\
\text { Preenchimento }\end{array}$ & $\begin{array}{c}\text { Tarifa } \\
\text { Intra-Quota }\end{array}$ & $\begin{array}{c}\text { Tarifa } \\
\text { Extra-Quota }\end{array}$ & Quota (Ton) & $\begin{array}{c}\text { Ocorrência de } \\
\text { Exportações } \\
\text { Brasileiras }\end{array}$ \\
\hline \multirow{11}{*}{ ISLÂNDIA } & Soja - grão & AT & 69,8 & 0,0 & 87,5 & 191 & - \\
\hline & Soja - farelo & AT & 60,0 & 180,0 & 87,5 & 1.686 & - \\
\hline & Soja - óleo & AT & 100,0 & 7,0 & 107,0 & 1.153 & - \\
\hline & Açúcar bruto & AT & 50,0 & 10,0 & 4,5 & 11.816 & - \\
\hline & Açúcar - outros & उAT & 97,4 & 15,9 & 60,1 & 414 & - \\
\hline & Carne de aves & $A U$ & 31,6 & 32,0 & 529,3 & 59 & $x$ \\
\hline & Carne bovina & $A U$ & 8,2 & 32,0 & 510,9 & 95 & - \\
\hline & Carne suína & $A U$ & 100,0 & 32,0 & 469,9 & 64 & - \\
\hline & Milho & AT & 80,0 & 180,0 & 87,5 & 1.690 & - \\
\hline & Derivados de cacau & AT & 100,0 & 21,3 & 95,0 & 5 & - \\
\hline & $\begin{array}{l}N^{\circ} \text { de Quotas Tarifárias e Valores } \\
\text { Médios (Islândia) }\end{array}$ & 12 & 69,7 & 51,0 & 203,9 & - & - \\
\hline \multirow{6}{*}{ NORUEGA } & Açúcar - outros & $2 \mathrm{AT}$ & 90,1 & 369,0 & 369,0 & 2.120 & - \\
\hline & Álcool etílico & AT & 83,8 & 424,0 & 424,0 & 56 & - \\
\hline & Carne de aves & 4AU-3AT & 21,0 & 394,5 & 520,5 & 1.885 & - \\
\hline & Carne bovina & $3 A T-1 A U$ & 56,2 & 279,3 & 514,5 & 1.178 & $x$ \\
\hline & Milho & $5 \mathrm{AT}$ & 30,1 & 323,8 & 161,9 & 21.300 & $x$ \\
\hline & $\begin{array}{l}N^{\circ} \text { de Quotas Tarifárias e Valores } \\
\text { Médios (Noruega) }\end{array}$ & 19 & 56,2 & 358,1 & 398,0 & - & - \\
\hline TOTAL & $\begin{array}{l}\mathrm{N}^{\circ} \text { de Quotas Tarifárias e Valores } \\
\text { Médios (Bloco) }\end{array}$ & 31 & 65,2 & 153,4 & 268,6 & - & - \\
\hline
\end{tabular}

Fonte: dados de pesquisa, WTO (2002); United States (2003) e Brasil (2003)

Os métodos utilizados alternam-se entre a tarifa aplicada e o leilão, e, via de regra, os volumes das quotas são bem pequenos e as tarifas, tanto intra quanto extraquota, são extremamente altas.

Um importante aspecto é a baixa performance exportadora brasileira para esses países. Na Islândia, de suas 12 quotas tarifárias, o Brasil apenas abastece esse mercado com carne de aves. Para a Noruega, exporta somente carne bovina e milho. Nesse sentido, um esforço das autoridades brasileiras, bem como do empresariado, pode garantir maior acesso.

\subsection{Países africanos}

A tabela 19 mostra que a África do Sul impõe 14 quotas tarifárias. Em todos os casos, exceto uvas, o nível de preenchimento é alto. Nota-se que farelo de soja, açúcar bruto, carne suína e algodão possuem preenchimento 
médio igual a 100\%, o que sugere que existe demanda para esses produtos e, portanto, podem representar oportunidades de acesso às exportações brasileiras.

Tabela 19. Informações sobre produtos agroindustriais de interesse ao Brasil sujeitos a quotas tarifárias em países africanos.

\begin{tabular}{|c|c|c|c|c|c|c|c|}
\hline País & Produto & $\begin{array}{c}\text { Método de } \\
\text { Administração }\end{array}$ & $\begin{array}{c}\text { Taxa de } \\
\text { Preenchimento }\end{array}$ & $\begin{array}{c}\text { Tarifa } \\
\text { Intra-Quota }\end{array}$ & $\begin{array}{c}\text { Tarifa } \\
\text { Extra-Quota }\end{array}$ & Quota (Ton) & $\begin{array}{c}\text { Ocorrência de } \\
\text { Exportações } \\
\text { Brasileiras } \\
\end{array}$ \\
\hline \multirow{13}{*}{$\begin{array}{l}\text { ÁFRICA DO } \\
\text { SUL }\end{array}$} & Soja - grão & AT & 98,6 & 20,0 & 40,0 & 1.717 & - \\
\hline & Soja - farelo & AT & 100,0 & 20,0 & 33,0 & 120.667 & $x$ \\
\hline & Açúcar bruto & AT & 100,0 & 20,0 & 105,0 & 62.037 & $x$ \\
\hline & Açúcar - outros & 2AT & 85,1 & 20,0 & 68,0 & 40.924 & $x$ \\
\hline & Café - grão & AT & 85,7 & 20,0 & 119,0 & 15.746 & $x$ \\
\hline & Carnes de aves & AT & 100,0 & 20,0 & 58,2 & 29.033 & $x$ \\
\hline & Carne bovina & $\mathrm{HI}$ & 94,5 & 20,0 & 99,3 & 26.254 & $x$ \\
\hline & Tabaco & LD & 90,5 & 20,0 & 44,0 & 16.773 & $x$ \\
\hline & Carne suína & AT & 100,0 & 20,0 & $\mathrm{~N}, \mathrm{D}$ & 4.691 & $x$ \\
\hline & Uva & LD & 12,0 & 20,0 & 23,0 & 397 & - \\
\hline & Milho & LD - AT & 71,9 & 20,0 & 57,9 & 269.000 & $x$ \\
\hline & Algodão & LD & 100,0 & 20,0 & 60,0 & 17.101 & $x$ \\
\hline & $\begin{array}{l}\mathrm{N}^{\circ} \text { de Quotas Tarifárias e Valores } \\
\text { Médios (África do Sul) }\end{array}$ & 14 & 86,5 & 20,0 & 64,3 & - & - \\
\hline \multirow{6}{*}{ MARROCOS } & Soja - grão & $\mathrm{FC}$ & 100,0 & 111,0 & 65,0 & 17.700 & $x$ \\
\hline & Açúcar bruto & $\mathrm{FC}$ & 100,0 & 168,0 & 168,0 & 274.330 & $x$ \\
\hline & Carne de aves & $\mathrm{FC}$ & 39,8 & 62,5 & 89,8 & 6.400 & $x$ \\
\hline & Carne bovina & $\mathrm{FC}$ & 100,0 & 82,5 & 239,0 & 5.000 & $x$ \\
\hline & Milho & $\mathrm{FC}$ & 100,0 & 122,0 & 53,3 & 204.400 & $x$ \\
\hline & $\begin{array}{l}\mathrm{N}^{\circ} \text { de Quotas Tarifárias e Valores } \\
\text { Médios (Marrocos) }\end{array}$ & 5 & 88,0 & 109,2 & 123,0 & - & - \\
\hline \multirow{3}{*}{ TUNÍSIA } & Açúcar bruto & $\mathrm{HI}$ & 80,0 & 15,0 & 100,0 & 100.000 & $x$ \\
\hline & Carne bovina & $\mathrm{HI}$ & 28,6 & 27,0 & 87,5 & 8.000 & - \\
\hline & $\begin{array}{l}N^{\circ} \text { de Quotas Tarifárias e Valores } \\
\text { Médios (Tunísia) }\end{array}$ & 2 & 54,3 & 21,0 & 93,8 & - & - \\
\hline TOTAL & $\begin{array}{l}N^{\circ} \text { de Quotas Tarifárias e Valores } \\
\text { Médios (Bloco) }\end{array}$ & 21 & 83,5 & 43,6 & 83,9 & - & - \\
\hline
\end{tabular}

Fonte: dados de pesquisa, WTO (2002); United States (2003) e Brasil (2003)

Nesse sentido, um fator importante é a alteração nas tarifas extraquota ou elevação da quota para trazer efetivamente maior acesso a mercado. Nesses casos, o nível tarifário praticado é inferior à média global de cada respectivo produto. Isso pode indicar que tarifas menores significam maior preenchimento das quotas. 
Verifica-se que os métodos adotados são tarifas aplicadas, licenças sobre demanda e alocação histórica. O método tarifa aplicada é adotado em três das quatro quotas tarifárias com preenchimento total; a outra se utiliza do método licenças sobre demanda.

Como o método mais utilizado é o de tarifa aplicada, a negociação da tarifa NMF extraquota não gera efetivamente maior acesso, ocorrendo o mesmo com a quota. Nesse caso, para que haja acesso aos produtos que se utilizam desse método de administração, é necessária a negociação das tarifas aplicadas, ou seja, a redução do patamar estabelecido de $20 \%$.

Para os demais métodos, a determinação do instrumento mais efetivo implica o conhecimento da demanda e oferta doméstica, bem como dos aspectos legais e burocráticos desse país.

O Marrocos, segundo a tabela 19, impõe cinco quotas tarifárias aos produtos de maior interesse ao Brasil. Entre elas, quatro preenchem completamente seu volume. Apenas a carne de aves não tem esse comportamento.

Via de regra as tarifas do Marrocos são bastante altas, sempre acima da média global. Porém os volumes das quotas são pequenos, o que facilita o preenchimento comum nesse país.

A Tunísia aplica só duas quotas tarifárias aos produtos escolhidos, ambas administradas por alocação histórica.

Açúcar bruto tem preenchimento alto, tarifa intraquota menor que a média global e tarifa extraquota alta. Seu volume é de 100.000 toneladas.

A carne bovina possui nível de preenchimento baixo e tarifas intra e extraquota reduzidas. Todavia o volume de quota é de 8.000 toneladas apenas, ou seja, condições internas devem explicar esse comportamento. 
O Brasil tem participação em quase todas as quotas tarifárias impostas pelos países africanos.

\subsection{Austrália}

A Austrália impõe somente uma quota tarifária sobre os produtos de maior interesse ao Brasil, especificamente sobre o tabaco, como se pode observar na tabela 20.

Tabela 20. Informações sobre produtos agroindustriais de interesse ao Brasil sujeitos a quotas tarifárias na Austrália.

\begin{tabular}{|c|c|c|c|c|c|c|c|}
\hline País & Produto & $\begin{array}{c}\text { Método de } \\
\text { Administração }\end{array}$ & $\begin{array}{c}\text { Taxa de } \\
\text { Preenchimento }\end{array}$ & $\begin{array}{c}\text { Tarifa } \\
\text { Intra-Quota }\end{array}$ & $\begin{array}{c}\text { Tarifa } \\
\text { Extra-Quota }\end{array}$ & Quota (Ton) & $\begin{array}{c}\text { Ocorrência de } \\
\text { Exportações } \\
\text { Brasileiras }\end{array}$ \\
\hline & Tabaco & AT & 100,0 & 14,2 & 25,0 & 11.500 & $x$ \\
\hline AUSTRÁLIA & $\begin{array}{l}\mathrm{N}^{0} \text { de Quotas Tarifárias e Valores } \\
\text { Médios }\end{array}$ & 1 & 100,0 & 14,2 & 25,0 & - & - \\
\hline
\end{tabular}

Fonte: dados de pesquisa, WTO (2002); United States (2003) e Brasil (2003)

Preenche $100 \%$ de sua quota, perfazendo anualmente o volume de 11.184 toneladas de fumo. O método utilizado é o da tarifa aplicada e o nível tarifário praticado é muito inferior à média global do produto. Isso indica que a prática de tarifas reduzidas, sob o sistema de quotas tarifárias, significa elevado preenchimento de quota.

Esse é o caso também de um regime extraquota ou quota, de forma que a redução da tarifa extra ou aumento da quota não são efetivos no intuito de alcançar maior acesso a mercado.

\subsection{Israel}

Israel impõe só três quotas tarifárias aos produtos escolhidos, dos quais duas possuem preenchimento completo da quota (carne bovina e suco de 
laranja). O terceiro produto (milho) possui alta taxa de preenchimento $(94,6)$, e, portanto acompanha uma tendência geral desse país de preencher suas quotas, conforme a tabela 21.

Tabela 21. Informações sobre produtos agroindustriais de interesse ao Brasil sujeitos a quotas tarifárias em Israel.

\begin{tabular}{|c|c|c|c|c|c|c|c|}
\hline País & Produto & $\begin{array}{c}\text { Método de } \\
\text { Administração }\end{array}$ & $\begin{array}{c}\text { Taxa de } \\
\text { Preenchimento }\end{array}$ & $\begin{array}{c}\text { Tarifa } \\
\text { Intra-Quota }\end{array}$ & $\begin{array}{c}\text { Tarifa } \\
\text { Extra-Quota }\end{array}$ & Quota (Ton) & $\begin{array}{c}\text { Ocorrência de } \\
\text { Exportações } \\
\text { Brasileiras } \\
\end{array}$ \\
\hline \multirow{4}{*}{ ISRAEL } & Carne bovina & $M X$ & 100,0 & 170,0 & 327,5 & 37.250 & $x$ \\
\hline & Suco de laranja & $\mathrm{HI}$ & 100,0 & 52,0 & 240,0 & 160 & $x$ \\
\hline & Milho & LD & 94,6 & 40,0 & 256,0 & 350 & $x$ \\
\hline & $\begin{array}{l}\mathrm{N}^{\circ} \text { de Quotas Tarifárias e Valores } \\
\text { Médios }\end{array}$ & 3 & 98,2 & 87,3 & 274,5 & - & $\cdot$ \\
\hline
\end{tabular}

Fonte: dados de pesquisa, WTO (2002); United States (2003) e Brasil (2003)

Os métodos de administração são diversos; nesse caso, são utilizados o mix de métodos, a alocação histórica e as licenças sobre demanda.

Os níveis tarifários praticados são bastante altos para a carne bovina, ultrapassando a média global do produto. Os outros produtos (suco de laranja e milho) possuem tarifa intraquota menor que a média global e tarifa extraquota muito elevada, o que as torna bastante proibitivas.

Os volumes das quotas, por sua vez, são bastante pequenos para o suco de laranja e para o milho, com 350 e 750 toneladas, respectivamente. Cabe lembrar que esse valor deve-se em grande parte aos acordos preferenciais mantidos com os Estados Unidos. A carne bovina, embora em sua quota tarifária também inclua animais vivos, estabelece 37.250 toneladas como quota, o que é um valor razoável quando comparado ao de outros países. 


\subsection{União Européia}

A União Européia impõe 30 quotas tarifárias aos produtos de maior interesse ao Brasil, para os quais utiliza principalmente os métodos licenças sobre demanda, first come,first served e alocação histórica para administrá-las.

A tabela 22 aponta que, entre as 30 quotas tarifárias, quatro atingem preenchimento médio de 100\% (açúcar bruto, açúcar-outros, uvas e bananas). Cabe ressaltar que a banana já foi alvo de alguns contenciosos; por isso, seu caso é amplamente discutido na literatura. Ressalta-se ainda, diferentemente do caso americano, que oficialmente as quotas de bananas são alocadas de forma histórica, conforme se verifica na realidade (Hermann, Kramb e Mönnich, 2000).

Tabela 22. Informações sobre produtos agroindustriais de interesse ao Brasil sujeitos a quotas tarifárias na União Européia.

\begin{tabular}{|c|c|c|c|c|c|c|c|}
\hline País & Produto & $\begin{array}{c}\text { Método de } \\
\text { Administração }\end{array}$ & $\begin{array}{c}\text { Taxa de } \\
\text { Preenchimento }\end{array}$ & $\begin{array}{c}\text { Tarifa } \\
\text { Intra-Quota }\end{array}$ & $\begin{array}{c}\text { Tarifa } \\
\text { Extra-Quota }\end{array}$ & Quota (Tom) & $\begin{array}{c}\text { Ocorrência de } \\
\text { Exportações } \\
\text { Brasileiras }\end{array}$ \\
\hline \multirow{10}{*}{$\begin{array}{l}\text { UNÃO } \\
\text { EUROPÉIA }\end{array}$} & Açúcar bruto & 2LD & 100 & 27,8 & 118,1 & 1.390 .163 & $x$ \\
\hline & Açúcar - outros & $\mathrm{FC}$ & 100 & 20 & 83,9 & 4.504 & $x$ \\
\hline & Carne de aves & $6 \mathrm{LD}$ & 96,3 & 16,3 & 45,7 & 29.900 & $x$ \\
\hline & Carne bovina & 7LD-1HI & 82,2 & 20 & 148,5 & 164.050 & $x$ \\
\hline & Carne suína & $6 \mathrm{LD}$ & 23,8 & 19,8 & 43,8 & 72.600 & $x$ \\
\hline & Suco de Laranja & $\mathrm{FC}$ & 26,8 & 13 & 15,2 & 1.500 & $x$ \\
\hline & Uva & $\mathrm{FC}$ & 100 & 9 & 17,6 & 1.500 & $x$ \\
\hline & Banana & $\mathrm{HI}$ & 100 & 18,9 & 171,6 & 2.200 .000 & $x$ \\
\hline & Laranja & $2 \mathrm{FC}$ & 48,9 & 10 & 27,5 & 20.000 & $x$ \\
\hline & Milho & $2 \mathrm{LD}$ & 85,5 & 38,1 & 71,5 & 2.500 .000 & $x$ \\
\hline TOTAL & $\begin{array}{l}N^{\circ} \text { de Quotas Tarifárias e Valores } \\
\text { Médios }\end{array}$ & 30 & 76,3 & 19,3 & 74,3 & - & - \\
\hline
\end{tabular}

Fonte: dados de pesquisa, WTO (2002); United States (2003) e Brasil (2003)

As quotas de açúcar bruto e outros, embora publicadas oficialmente como administradas por licenças sobre demanda, é sabido pela literatura, são 
alocadas de forma específica aos países $\mathrm{ACP}^{19}$ (Matthews e Laroche-Dupraz, 2002). Ou seja, o mesmo caso de falta de transparência que o caso americano do açúcar.

Os níveis tarifários praticados pela UE são geralmente reduzidos para a tarifa intraquota (menores que a média global por produto) e heterogêneas dependendo do produto, para a tarifa extraquota.

Destaque-se também a carne suína, de grande consumo na Europa, e taxa de preenchimento em torno de $23,8 \%$, tarifas intra e extraquota reduzidas e volume de 67.600 toneladas, ou seja, a produção interna deve explicar esse comportamento, uma vez que é administrada por licenças sobre demanda.

O suco de laranja é outro produto que merece atenção. Tem volume extremamente baixo de quota, 1.500 toneladas, taxa de preenchimento também baixa, 26,8\%, e ainda tarifas intra e extraquota menores que a média global. Nesse caso, também o baixo nível de preenchimento deve estar vinculado às condições domésticas de oferta, especificamente a grande produção do produto na Espanha.

Como o principal destino das exportações agroindustriais brasileiras, as quotas tarifárias da União Européia devem ter atenção especial das autoridades brasileiras, seja no aspecto multilateral, seja nos acordos regionais que estão sendo negociados. Embora o Brasil consiga exportar em todas as quotas tarifárias registradas, o mercado da União Européia é um dos mais relevantes mundialmente. Assim, a verificação pontual de cada produto

\footnotetext{
${ }^{19}$ Países ACP é um grupo de países da África, Caribe e Pacífico, formado por ex-colônias dos países membros da União Européia. As nações da ACP recebem da União Européia tratamento preferencial e outras formas de assistência, conforme estipulado pelos Acordos de Lomé e de Cotonou. http://www.iconebrasil.org.br/index_glossario_1.asp?idpalavra=113
} 
agroindustrial deve ser considerada no que tange à abertura de mercados agrícolas.

\subsection{Outros países}

Alguns países que adotam quotas tarifárias não puderam ser analisados, devido, principalmente, à grande dificuldade por parte de nações pobres em manter uma publicação sistemática de informações sobre comércio e à falta de informações pregressas daqueles países que passaram a fazer parte da OMC recentemente.

Essas nações são Bulgária, Chile, China, Costa Rica, Croácia, El Salvador, Letônia, Lituânia, Nicarágua, Romênia e Taiwan.

Pode-se notar que uma parte delas é constituída por países latinoamericanos pobres (Costa Rica, El Salvador e Nicarágua) e outra por nações que recentemente entraram no esquema multilateral de comércio (China, Bulgária, Croácia, Letônia, Lituânia e Romênia).

\subsection{Indonésia, Japão, Nova Zelândia e Suíça}

Indonésia, Japão, Nova Zelândia e Suíça não impõem quotas tarifárias aos produtos de maior interesse ao Brasil e, por isso, não tiveram seus sistemas descritos e avaliados.

\subsection{Uma discussão sobre a adoção de quotas tarifárias em 26 países analisados}

Essa análise país a país buscou conferir como as quotas e as tarifas médias são impostas e quais as características particulares de cada nação no que se refere a seu sistema de quotas tarifárias. 
Para distinguir entre os 26 países analisados aqueles que têm influência relevante sobre as exportações brasileiras, este trabalho procurará sintetizar as informações até aqui apresentadas.

Com esse intuito foi construída a tabela 23 , que mostra o nível de preenchimento médio e os níveis tarifários praticados por cada método de administração registrado. Pode-se observar, conforme DeGorter e Sheldon (2001), Skully (2001a, 2001b) e Abbott (2001), que os métodos empresa estatal e grupo de produtores determinam elevado índice de preenchimento, que o método leilão possui preenchimento baixo e que os demais métodos de administração têm comportamento bastante heterogêneo, o que não permite uma conclusão definitiva sobre seu comportamento esperado.

A tabela 23 também mostra que o nível tarifário médio praticado em cada um dos métodos de administração é relativamente elevado até mesmo para a importação intraquota. 
Tabela 23. Taxa de preenchimento médio e níveis tarifários médios por método de administração.

\begin{tabular}{lccc}
\hline Método de Administração & $\begin{array}{c}\text { Preenchimento } \\
(\%)\end{array}$ & $\begin{array}{c}\text { Tarifa } \\
\text { Intraquota }\end{array}$ & $\begin{array}{c}\text { Tarifa } \\
\text { Extraquota }\end{array}$ \\
\hline Mix de métodos (MX) & 85,2 & 59,9 & 212,9 \\
Licenças sobre demanda (LD) & 58,7 & 39,9 & 85,7 \\
Tarifa aplicada (TA) & 75,7 & 86,1 & 127,7 \\
First come, first served (FC) & 57,6 & 41,2 & 78,8 \\
Leilão (LE) & 53,0 & 61,9 & 361,4 \\
Empresas estatais (EE) & 94,6 & 40,0 & 72,5 \\
Grupo de produtores (GP) & 75,9 & 20,0 & 119,7 \\
Alocação histórica (HI) & 73,8 & 67,5 & 195,7 \\
Outros (OT) & 100,0 & 209,0 & 209,0 \\
\hline
\end{tabular}

Fonte: dados de pesquisa, WTO (2002) e United States (2003)

A média tarifária de $20 \%$, referente à adoção do método grupo de produtores, embora seja a menor entre as tarifas médias por método de administração, é alta para a importação de soja e seus derivados na Tailândia, onde é aplicada ${ }^{20}$. Ou seja, essa quota tarifária não está cumprindo seu papel, pelo menos na retórica, de garantir acesso a mercado, mas cumprindo, na prática, função de restrição quantitativa à importação.

\footnotetext{
${ }^{20}$ Neste trabalho, o método grupo de produtores é utilizado apenas pela Tailândia, a qual impõe três quotas tarifárias para soja e seus derivados. Por isso é que essa comparação entre a tarifa de $20 \%$ e a prática geral pode ser realizada.
} 
Ressalte-se ainda que todas as tarifas médias são picos tarifários, inclusive para tarifas intraquota, excetuando o método grupo de produtores, mas, conforme dito anteriormente, esse valor se refere à tarifa imposta pela Tailândia sobre soja e derivados, o que é um montante muito elevado para o produto que, em geral, tem tarifas baixas.

Uma análise à luz do que foi apresentado será realizada. Entretanto, devido ao pequeno impacto que seria proporcionado pela liberalização do sistema de quotas tarifárias em economias de pequena expressão, optou-se pela restrição do número de países analisados como uma síntese deste trabalho. O critério escolhido foi o de maior valor das exportações agroindustriais brasileiras por destino, ocorridas no ano de 2002, conforme apontado na tabela 24. Acredita-se que quanto maior a participação de um país nas exportações brasileiras, maior a sua influência no comércio.

Tabela 24. Exportações agroindustriais brasileiras, ranking de principais países importadores, ano 2002.

\begin{tabular}{lrr}
\hline & Mil US\$ & $\%$ \\
\hline 1. União Européia & $6,993,527$ & 28.2 \\
2. Estados Unidos & $1,313,238$ & 5.3 \\
3. China & $1,046.299$ & 4.2 \\
4. Japão & 781,471 & 3.1 \\
5. Coréia do Sul & 303,891 & 1.2 \\
6. Chile & 223,201 & 0.9 \\
7. Marrocos & 192,641 & 0.8 \\
8. Canadá & 168,503 & 0.7 \\
9. Indonésia & 120,892 & 0.5 \\
10. Tailândia & 118,449 & 0.5 \\
11. África do Sul & 116,810 & 0.5 \\
12. Noruega & 102,055 & 0.4 \\
13. Romênia & 86,384 & 0.3 \\
14. México & 82,225 & 0.3 \\
15. Malásia & 82,115 & 0.3 \\
16. Outros & $11,706,918$ & 47.1 \\
TOTAL & $24,838,914$ & \\
\hline
\end{tabular}

Fonte: Brasil (2003) 
Optou-se também pela restrição no número de produtos analisados. O pequeno número de quotas tarifárias para determinados produtos e sua adoção em poucos países determinaram sua exclusão na proposta de síntese. Essas características também não determinariam um impacto relevante caso houvesse liberalização do sistema de quotas tarifárias. Assim, o critério adotado foi o de maior número de quotas tarifárias impostas sobre os principais produtos agroindustriais da pauta exportadora brasileira.

A tabela 25 é a síntese da aplicação das quotas tarifárias sobre as exportações brasileiras, indicando, portanto, dez países e nove produtos. A tabela 25 é composta pelos seguintes países: União Européia (UE), Estados Unidos (EUA), Coréia do Sul (COR), Marrocos (MAR), Canadá (CAN), Tailândia (TAl), África do Sul (AFS), Noruega (NOR), México (MEX) e Malásia (MAL). Japão e Indonésia não impõem quotas tarifárias sobre os produtos analisados neste trabalho e China e Romênia não possuem informações completas e não foram analisadas, e, por isso, não constam da tabela proposta. 
Tabela 25. Síntese da adoção do sistema de quotas tarifárias. Principais países e produtos ${ }^{21}$.

\begin{tabular}{|c|c|c|c|c|c|c|c|c|c|c|c|}
\hline & & $\begin{array}{c}\text { União } \\
\text { Européia }\end{array}$ & $\begin{array}{l}\text { Estados } \\
\text { Unidos }\end{array}$ & $\begin{array}{c}\text { Coréia do } \\
\text { Sul }\end{array}$ & Marrocos & Canadá & Tailândia & $\begin{array}{c}\text { África do } \\
\text { Sul }\end{array}$ & Noruega & México & Malásia \\
\hline \multirow{6}{*}{$\begin{array}{c}\text { Açúcar } \\
\text { Bruto }\end{array}$} & $\mathrm{N}^{\circ}$ quotas tarifárias & 2 & 1 & - & 1 & - & 1 & 1 & - & 1 & 1 \\
\hline & Método de administração & 2LD & $1 \mathrm{FC}$ & - & $1 \mathrm{FC}$ & - & $1 \mathrm{LD}$ & 1TA & - & 1TA & 1LD \\
\hline & Tarifa intraquota & 27,8 & 4,0 & - & 168,0 & - & 65,0 & 20,0 & - & 50,0 & 22,5 \\
\hline & Tarifa extraquota & 118,1 & 93,8 & - & 168,0 & - & 94,0 & 105,0 & - & 125,8 & 35,6 \\
\hline & Quota (ton) & 1.390 .163 & 1.117.195 & - & 274.330 & - & 13.760 & 62.037 & - & 183.800 & 29.600 \\
\hline & Taxa de preenchimento & 100,0 & 99,5 & - & 100,0 & - & 0,0 & 100,0 & - & 82,0 & 6,5 \\
\hline \multirow{6}{*}{$\begin{array}{l}\text { Açúcar - } \\
\text { Outros }\end{array}$} & $\mathrm{N}^{\circ}$ quotas tarifárias & 1,0 & 5 & - & - & - & - & 2 & 2 & - & - \\
\hline & Método de administração & $1 F C$ & $5 \mathrm{FC}$ & - & - & - & - & $2 \mathrm{TA}$ & 2TA & - & - \\
\hline & Tarifa intraquota & 20,0 & 8,0 & - & - & - & - & 20,0 & 369,0 & - & - \\
\hline & Tarifa extraquota & 83,9 & 40,4 & - & - & - & - & 68,0 & 369,0 & - & - \\
\hline & Quota (ton) & 4.504 & 102.500 & - & - & - & - & 40.924 & 2.120 & - & - \\
\hline & Taxa de preenchimento & 100,0 & 68,0 & - & - & - & - & 85,1 & 90,1 & - & - \\
\hline \multirow{6}{*}{$\begin{array}{c}\text { Carne de } \\
\text { Aves }\end{array}$} & $\mathrm{N}^{\circ}$ quotas tarifárias & 6 & - & 1 & 1 & 2 & - & 1 & 7 & 1 & - \\
\hline & Método de administração & 6LD & - & $1 \mathrm{LE}$ & 1FC & $2 \mathrm{MX}$ & - & $1 \mathrm{TA}$ & 4LE, 3TA & 1TA & - \\
\hline & Tarifa intraquota & 16,3 & - & 20,0 & 62,5 & 4,7 & - & 20,0 & 394,5 & 50,0 & - \\
\hline & Tarifa extraquota & 45,7 & - & N.D. & 89,8 & 203,5 & - & 58,2 & 520,5 & 225,2 & - \\
\hline & Quota (ton) & 29.900 & - & 6.500 & 6.400 & 45.432 & - & 29.033 & 1.885 & 40.543 & - \\
\hline & Taxa de preenchimento & 96,3 & - & 90,0 & 39,8 & 99,8 & - & 100,0 & 21,0 & 100,0 & - \\
\hline \multirow{6}{*}{$\begin{array}{l}\text { Carne } \\
\text { Bovina }\end{array}$} & $\mathrm{N}^{\circ}$ quotas tarifárias & 8 & 1 & 1 & 1 & 1 & - & 1 & 4 & - & - \\
\hline & Método de administração & 7LD, 1HI & $1 \mathrm{FC}$ & $1 \mathrm{MX}$ & $1 \mathrm{FC}$ & 1LD & - & $1 \mathrm{HI}$ & 3TA, 1LE & - & - \\
\hline & Tarifa intraquota & 20,0 & 4,9 & 41,6 & 82,5 & 0,0 & - & 20,0 & 279,3 & - & - \\
\hline & Tarifa extraquota & 148,5 & 26,4 & 40,0 & 239,0 & 26,5 & - & 99,3 & 514,5 & - & - \\
\hline & Quota (ton) & 164.050 & 696.621 & 225.000 & 5.000 & 76.409 & - & 26.254 & 1.178 & - & - \\
\hline & Taxa de preenchimento & 82,2 & 67,8 & 84,5 & 100,0 & 99,2 & - & 94,5 & 56,2 & - & - \\
\hline \multirow{6}{*}{$\begin{array}{l}\text { Carne } \\
\text { Suína }\end{array}$} & $\mathrm{N}^{\circ}$ quotas tarifárias & 6 & - & 1 & - & - & - & 1 & - & - & 1 \\
\hline & Método de administração & $6 L D$ & - & $1 \mathrm{LE}$ & - & - & - & $1 \mathrm{TA}$ & - & - & $1 \mathrm{LD}$ \\
\hline & Tarifa intraquota & 19,8 & - & 25,0 & - & - & - & 20,0 & - & - & 40,0 \\
\hline & Tarifa extraquota & 43,8 & - & 25,0 & - & - & - & N.D. & - & - & 138,6 \\
\hline & Quota (ton) & 72.600 & - & 18.275 & - & - & - & 4.691 & - & - & 1.727 \\
\hline & Taxa de preenchimento & 23,8 & - & 100 & - & - & - & 100 & - & - & 0 \\
\hline \multirow{6}{*}{ Milho } & $\mathrm{N}^{\circ}$ quotas tarifárias & 2 & - & 2 & 1 & - & 1 & 2 & 5 & 1 & - \\
\hline & Método de administração & $2 \mathrm{LD}$ & - & $1 \mathrm{LD}, 1 \mathrm{HI}$ & $1 \mathrm{FC}$ & - & $1 \mathrm{EE}$ & $1 \mathrm{LD}, 1 \mathrm{TA}$ & 5TA & 1TA & - \\
\hline & Tarifa intraquota & 38,1 & - & 2,5 & 122,0 & - & 20,0 & 20,0 & 323,8 & 50,0 & - \\
\hline & Tarifa extraquota & 71,5 & - & 316,0 & 53,3 & - & 73,0 & 57,9 & 161,9 & 194,0 & - \\
\hline & Quota (ton) & 2.500 .000 & - & 6.102 .100 & 204.400 & - & 54.700 & 269.000 & 21.300 & 2.501 .000 & - \\
\hline & Taxa de preenchimento & 85,5 & - & 100,0 & 100,0 & - & 98,6 & 71,9 & 30,1 & 100,0 & - \\
\hline \multirow{6}{*}{ Cacau } & $\mathrm{N}^{\circ}$ quotas tarifárias & - & 3 & - & - & - & - & - & - & - & - \\
\hline & Método de administração & - & $3 \mathrm{FC}$ & - & - & - & - & - & - & - & - \\
\hline & Tarifa intraquota & - & 5,7 & - & - & - & - & - & - & - & - \\
\hline & Tarifa extraquota & - & 22,8 & - & - & - & - & - & - & - & - \\
\hline & Quota (ton) & - & 30.604 & - & - & - & - & - & - & - & - \\
\hline & Taxa de preenchimento & - & 42,1 & - & - & - & - & - & - & - & - \\
\hline \multirow{6}{*}{ Tabaco } & $\mathrm{N}^{\circ}$ quotas tarifárias & - & 1 & - & - & - & 1 & 1 & - & - & 1 \\
\hline & Método de administração & - & $1 \mathrm{FC}$ & - & - & - & $1 \mathrm{EE}$ & $1 \mathrm{LD}$ & - & - & $1 \mathrm{HI}$ \\
\hline & Tarifa intraquota & - & 20,3 & - & - & - & 60,0 & 20,0 & - & - & 879,0 \\
\hline & Tarifa extraquota & - & 350,0 & - & - & - & 72,0 & 44,0 & - & - & $2.627,1$ \\
\hline & Quota (ton) & - & 112.950 & - & - & - & 6.435 & 16.773 & - & - & 2.500 \\
\hline & Taxa de preenchimento & - & 59,3 & - & - & - & 90,5 & 90,5 & - & - & 100,0 \\
\hline \multirow{6}{*}{ Algodão } & $\mathrm{N}^{\circ}$ quotas tarifárias & - & 7 & - & - & - & - & 1 & - & - & - \\
\hline & Método de administração & - & $7 \mathrm{FC}$ & - & - & - & - & $1 \mathrm{LD}$ & - & - & - \\
\hline & Tarifa intraquota & - & 1,8 & - & - & - & - & 20,0 & - & - & - \\
\hline & Tarifa extraquota & - & 14,8 & - & - & - & - & 60,0 & - & - & - \\
\hline & Quota (ton) & - & 76.545 & - & - & - & - & 17.101 & - & - & - \\
\hline & Taxa de preenchimento & - & 14,9 & - & - & - & - & 100,0 & - & - & - \\
\hline
\end{tabular}

Fonte: dados de pesquisa, WTO (2002) e United States (2003)

${ }^{21}$ Métodos de administração são Mix de métodos (MX), Licenças sobre demanda (LD), Tarifa aplicada (TA), First come,first served (FC), Leilão (LE), Empresas estatais (EE), Grupo de produtores (GP), Alocação histórica (HI) e Outros (OT). 
Os produtos analisados, seguindo o disposto na tabela 8 deste trabalho, são açúcar bruto (26 quotas tarifárias), açúcar - outros (32), carne de aves (53), carne bovina (53), carne suína (44), milho (38), cacau (15), tabaco (13) e algodão (11).

$\mathrm{Na}$ tabela 25 , pode-se verificar que nem todos os produtos estão sujeitos às quotas tarifárias dentro do universo de países estudados. A União Européia impõe quotas tarifárias para seis dos nove produtos escolhidos, de forma que não protege com esse instrumento o cacau e derivados, o tabaco e o algodão.

Já para os Estados Unidos, não há utilização de quotas para as carnes de aves, carnes suínas e para o milho. Esse país protege seu setor açucareiro, de carnes bovinas, derivados de cacau, tabaco e algodão, este último com sete quotas tarifárias para um único produto ${ }^{22}$.

A Coréia do Sul impõe quotas tarifárias sobre as carnes em geral e para o milho. O Marrocos protege, com quatro quotas tarifárias, seu açúcar bruto, as carnes de aves e bovinas e o milho. O Canadá estabelece suas quotas para as carnes de frango e bovinas.

A África do Sul é a nação que mais impõe quotas tarifárias entre os países apresentados na tabela 25 , deixando de fora somente cacau e derivados. A Noruega protege seu açúcar - outros (entre esses açúcares está o refinado), o que sugere também a presença de escalada tarifária. Esse nação protege ainda as carnes de aves e bovina e o milho.

O México impõe quotas tarifárias ao açúcar bruto, carne de aves e milho. Ressalta-se que o milho importado dos Estados Unidos possui

22 A classificação do algodão em pluma para os Estados Unidos segue uma série de especificações bastante detalhadas, o que determina o número elevado de quotas tarifárias para o produto. 
preferência devido à Área de Livre Comércio da América do Norte (NAFTA) ${ }^{23}$, para o qual enfrenta tarifa reduzida. A concorrência americana acabou por criar problemas a esse país nesse setor. A integração tem suas nuances; por isso, qualquer compromisso de comércio deve ser bem avaliado, o que afirma a relevância do presente trabalho. A Malásia protege com quotas tarifárias seu açúcar bruto, carne suína e tabaco.

Do ponto de vista setorial, nos dez países apontados na tabela 25, o açúcar bruto, as carnes de aves e as bovinas e o milho são aqueles produtos mais protegidos por quotas tarifárias. O açúcar bruto na União Européia e nos Estados Unidos possui uma expressiva quota, entretanto, conforme aponta Bureau (1999) e Skully (2001a), seu sistema de administração, embora notificado como licenças sobre demanda e first come, first served respectivamente, sofre a influência de acordos preferenciais, ou seja, volumes de importação destinados a países específicos, geralmente distribuídos aos países ACP e países participantes dos sistemas gerais de preferência (SGP) ${ }^{24}$.

Estados Unidos e União Européia adotam tarifas intraquota relativamente reduzidas e tarifas extraquota muito altas. Este é o caso em que as tarifas extraquota são tão altas que impedem qualquer possibilidade de importação extraquota. Daí o elevado índice de preenchimento das quotas.

\footnotetext{
${ }^{23}$ Área de Livre Comércio da América do Norte (NAFTA) constitui um acordo para criação de uma área de livre comércio entre Estados Unidos, Canadá e México. Visa à eliminação de barreiras comerciais e à facilitação do deslocamento de bens e serviços entre os países membros, aumentando substancialmente o fluxo de comércio e os investimentos intrabloco. http://www.iconebrasil.org.br/index_glossario_1.asp?idpalavra=105

${ }^{24}$ Sistema Geral de Preferência (SGP) O sistema geral de preferências é a principal forma de tratamento especial e diferenciado de países desenvolvidos em relação àqueles em desenvolvimento. Consiste na concessão de preferências discricionárias e não-recíprocas por meio de redução tarifária ou livre entrada para os produtos importados dos países em desenvolvimento. http://www.iconebrasil.org.br/index_glossario_1.asp?idpalavra=136
} 
As demais nações estabelecem quotas bem mais modestas. Verificase que, excetuando a Malásia, os demais países estabeleceram tarifas extraquota bastante elevadas. Marrocos adota uma única tarifa de 168\% para o produto, representando o caso de que a quota tarifária não é exercida, sendo, portanto, uma espécie de precaução contra futuros problemas no setor.

A Tailândia aplica uma tarifa de $94 \%$ e $65 \%$ para o açúcar bruto, tarifas extraquota e intraquota respectivamente. O patamar dessas tarifas é bastante elevado. Verifica-se ainda que esse país importou açúcar bruto nos últimos anos, o que não confere com o preenchimento de a quota ser de $0 \%$. Nesse caso, essa estatística deve estar relacionada a problemas de informação e publicação dos dados na OMC ou do órgão responsável tailandês.

África do Sul e México impõem tarifas extraquota elevadas e tarifas intraquota aceitáveis, o que sugere o alto nível de preenchimento das quotas.

A quota mais expressiva para o açúcar - outros, entre os quais, destaca-se o açúcar refinado, é a dos Estados Unidos. Os demais países estabeleceram montantes menores. Excetuando a Noruega, em todos os casos, pode-se verificar que há a adoção de uma tarifa extraquota elevada e uma tarifa intraquota aceitável. No caso da União Européia e África do Sul, essa postura corresponde a um nível alto de preenchimento. No caso americano, verifica-se que quatro das cinco quotas apontadas são exclusivas ao México, o que pode explicar em parte o baixo nível de preenchimento. A Noruega adota tarifas muito elevadas, entretanto, como pode ser visto, adota uma única tarifa, ou seja, é um caso em que a quota não é exercida e, dessa forma, a importação do produto sofre mais com a imposição do pico tarifário do que com a quota tarifária propriamente dita.

México e Canadá são os países que estabeleceram um maior volume de quota para as carnes de aves. Este setor pode ser dividido em dois grupos nesses países: aqueles que impõem tarifas extraquotas extremamente 
elevadas (Canadá, Noruega e México) e os que impõem tarifas extraquota não tão elevadas (União Européia, Coréia do Sul e Marrocos).

Verifica-se para as carnes de aves que México, Noruega e Marrocos impõem tarifas intraquota altas, sendo que os demais praticam tarifas permissíveis. Isso se reflete no nível de preenchimento baixo, exceto o México, que tem um volume de quota de 225,2 toneladas, muito pequena e de fácil preenchimento. Cabe destacar também que o preenchimento das quotas das carnes de frango, bem como as demais carnes, é fortemente influenciado por medidas sanitárias. Dessa forma, o preenchimento baixo pode também estar vinculado a problemas sanitários dos alimentos, além das questões estritamente tarifárias.

A carne bovina possui quotas mais expressivas quando comparadas às quotas das carnes de aves. União Européia, Marrocos, África do Sul e Noruega estabeleceram picos tarifários para esses produtos. A tarifa intraquota, entretanto, somente é proibitiva no Marrocos e na Noruega. Verifica-se um comportamento bastante adverso quanto à adoção de tarifas altas e aceitáveis e ao preenchimento das quotas. É possível, como no caso das carnes de aves, que medidas sanitárias e condições políticas e institucionais interfiram nesse setor, provocando esse comportamento bastante variável.

Somente a União Européia determina uma quota para carne suína expressiva. Os níveis tarifários são aceitáveis, exceto a tarifa extraquota da Malásia. Nota-se ainda um nível de preenchimento baixo para Europa e Malásia. O primeiro pode estar vinculado a questões sanitárias, uma vez que algumas das quotas referem-se a carnes frescas. A quota da Malásia acompanha o caso do açúcar bruto da Tailândia. Possivelmente, a publicação das informações pela OMC ou pelo órgão responsável malaio esteja equivocada, uma vez que ocorreu importação do produto em anos recentes. 
O caso das quotas tarifárias do milho é peculiar devido ao grande volume das quotas da União Européia, Coréia do Sul e México, volume que pode ser difícil de ser preenchido. Em todos os casos, a tarifa extraquota é extremamente alta. Notadamente a baixa tarifa intraquota adotada pela Tailândia beneficia o preenchimento total da quota. O mesmo não ocorre com a União Européia. Ao não exigir o cumprimento da sua quota para milho, Marrocos e Noruega estabelecem tarifas extraquota inferiores às tarifas intraquota, sendo mais um caso de precaução contra possíveis problemas futuros.

O México adota uma tarifa intraquota alta, mas que não se reflete no preenchimento das quotas. Tailândia e África do Sul possuem comportamento comum, altas tarifas extraquota e tarifas intraquota aceitáveis.

Somente os Estados Unidos aplicam quotas tarifárias para os derivados de cacau. Entretanto, as tarifas reduzidas não refletem alto nível de preenchimento das quotas.

O país que estabelece a maior quota para o fumo são os Estados Unidos. Ressalte-se que é muito superior às demais. É comum serem impostas elevadas tarifas extraquota sobre o fumo, caracterizadas como picos tarifários, expressas em valores extremamente alto, que podem chegar aos 2.627,1\% esta é a tarifa adotada na Malásia - isto demonstra seu grau de proteção. Com exceção da Noruega, o nível de preenchimento é alto, em alguns casos chegando a $100 \%$.

Nesse sentido, têm-se tarifas extremamente altas, inclusive para tarifas intraquota, mas que determinam taxas de preenchimento altas.

Nos Estados Unidos há a imposição de tarifas aceitáveis para o algodão, entretanto, a taxa de preenchimento é muito pequena. Por outro lado, a África do Sul impõe tarifas maiores que os Estados Unidos, contudo, seu 
preenchimento é de $100 \%$. Nesse caso, além de condições de demanda, o baixo preenchimento da quota de algodão dos Estados Unidos pode estar relacionado às condições políticas do setor, uma vez que os Estados Unidos são grandes produtores do produto e possuem um forte lobby em seu Congresso.

A tabela 25 também mostra o uso de diferentes métodos de administração para um mesmo produto. Ao contrário do disposto na tabela 3 , para os países que mais influenciam as exportações brasileiras, o método mais comum é o de licenças sobre demanda (31 vezes), seguido do first come,first served (23 vezes). Tarifa aplicada (22 vezes), o método de administração mais comum adotado mundialmente, aparece somente em terceiro lugar, o que sugere que os produtos contemplados pela tabela 25 exigem um nível de proteção mais intenso, uma vez que os métodos LD e FC dispõem de mais possibilidades de controle de mercado por parte do governo. Ou seja, esse fato indica que os produtos escolhidos são sensíveis politicamente.

Verifica-se que o método de licenças sobre demanda, em geral, estabelece um nível de preenchimento alto. O mesmo não ocorre com o método first come,first served. Cerca de metade das quotas que se valem desse método tem taxa de preenchimento de intermediário a baixo. $\mathrm{O}$ método da tarifa aplicada segue o mesmo comportamento do método licenças sobre demanda, em geral, possui preenchimento elevado, e pontualmente estabelece uma taxa de preenchimento de intermediário a baixo. Os demais métodos estabelecem preenchimento alto.

Cabe destacar, segundo DeGorter e Sheldon (2001) e Abbott (2001), que o baixo preenchimento das quotas não significa ineficiência. Esse comportamento pode estar associado a questões de demanda doméstica do país importador e custos de transação elevados, uma vez que são muitos os entraves burocráticos impostos aos exportadores. 
Entretanto, o Brasil ainda consegue exportar para a maioria dos países constantes da tabela 25. Para ilustrar essa afirmação, foi construída a tabela 26, utilizando dados sobre as exportações brasileiras no período de 2000 a 2002, disponibilizados pela Secretaria de Comércio Exterior (Secex), do Ministério do Desenvolvimento, Indústria e Comércio Exterior (MDIC). Essa tabela indica se ocorreu exportação brasileira para os países que adotam quotas tarifárias.

Entre os dez países constantes da tabela 25, o Brasil não encontra nenhum acesso para seus principais produtos agroindustriais apenas no México. Não há registro de qualquer importação de açúcar bruto, carne de aves ou milho pelo México segundo dados da Secex/MDIC nos anos de 2000 a 2002.

Outras três nações, Tailândia, Noruega e Malásia, em casos isolados, também não oferecem acesso a produtos brasileiros. Nota-se que não é oferecido nenhum acesso ao açúcar em três dos quatro países apontados, o que denota a sensibilidade desse produto no comércio internacional. Essa característica é acompanhada por milho e carne de aves - principalmente carne de frango - na Tailândia, Noruega e no México, e isoladamente a carne suína na Malásia.

Nos casos em que o Brasil não possui nenhum acesso, o questionamento é se efetivamente esse resultado se deve à imposição do sistema de quotas tarifárias ou se não houve demanda por importação. Uma vez que as informações da tabela 26 são apenas um indicativo quando a presença de quota preenchida em parte pelo Brasil, somente um estudo aprofundado poderia responder a essa questão. 
Tabela 26. Performance exportadora brasileira de produtos agroindustriais sujeitos a quotas tarifárias, período 2000-2002* .

\begin{tabular}{lcccccccccc}
\hline & UE & EUA & COR & MAR & CAN & TAI & AFS & NOR & MEX MAL \\
\hline Açúcar Bruto & + & + & $\bullet$ & + & $\bullet$ & - & + & $\bullet$ & - & + \\
Açúcar - Outros & + & + & $\bullet$ & $\bullet$ & $\bullet$ & $\bullet$ & + & - & $\bullet$ & $\bullet$ \\
Carne de Aves & + & $\bullet$ & + & + & + & $\bullet$ & + & - & - & $\bullet$ \\
Carne Bovina & + & + & + & + & + & $\bullet$ & + & + & $\bullet$ & $\bullet$ \\
Carne Suína & + & $\bullet$ & + & $\bullet$ & $\bullet$ & $\bullet$ & + & $\bullet$ & $\bullet$ & - \\
Milho & + & $\bullet$ & + & + & $\bullet$ & - & + & + & - & $\bullet$ \\
Cacau & $\bullet$ & + & $\bullet$ & $\bullet$ & $\bullet$ & $\bullet$ & $\bullet$ & $\bullet$ & $\bullet$ & $\bullet$ \\
Tabaco & $\bullet$ & + & $\bullet$ & $\bullet$ & $\bullet$ & + & + & $\bullet$ & $\bullet$ & + \\
Algodão & $\bullet$ & + & $\bullet$ & $\bullet$ & $\bullet$ & $\bullet$ & + & $\bullet$ & $\bullet$ & $\bullet$ \\
\hline
\end{tabular}

Fonte: dados de pesquisa e Brasil (2003)

(+) Ocorrência de exportação brasileira no triênio 2000-2002

(-) Não-ocorrência de exportação brasileira no triênio 2000-2002

$(\bullet)$ Não-imposição de quota tarifária

(*) UE (União Européia), EUA (Estados Unidos), COR (Coréia do Sul), MAR (Marrocos), CAN (Canadá), TAl (Tailândia), AFS (África do Sul), NOR (Noruega), MEX (México) e MAL (Malásia)

Ao considerar os casos em que o Brasil consegue algum acesso aos países analisados, podemos verificar que União Européia, Estados Unidos, Coréia do Sul, Marrocos, Canadá e África do Sul compram do Brasil em todos os casos em que ocorre a imposição de quotas tarifárias. Porém a dúvida reside se o Brasil possui quota, ou seja, se o processo de distribuição de direitos de importação contempla o Brasil (ou empresas parceiras de empresas brasileiras) com uma parcela de mercado e se ela é significativa.

A taxa de preenchimento completo, ou seja, de 100\%, consta de 15 das 43 quotas tarifárias apresentadas na tabela 25. Nesse sentido, o Brasil 
pode estar exportando para esses países de forma intraquota ou extraquota. As informações disponibilizadas na OMC e pelas autoridades brasileiras não distinguem entre as duas modalidades de exportação. Nesses casos, portanto, a verificação rigorosa para cada quota tarifária particular pode vir a responder a essa questão. Problemas dessa ordem são encontrados para o açúcar bruto na União Européia, no Marrocos e na África do Sul, para açúcar - outros na União Européia, para carne de aves na África do Sul e no México, para carne bovina no Marrocos, para carne suína na Coréia do Sul e África do Sul, para o milho na Coréia do Sul, no Marrocos e México, para o tabaco na Malásia e para o algodão na África do Sul.

Ressalte-se que o México preenche em $100 \%$ suas quotas para carnes de aves e milho, entretanto não oferece nenhum acesso a esses produtos com origem brasileira.

Quando o preenchimento não é completo e ocorre exportação brasileira, a indicação é a de que o Brasil é contemplado com a alocação das quotas para importação. Porém, não se descarta a hipótese de importação extraquota.

A partir do estudo caso a caso, sob o enfoque brasileiro, pode-se dividir três grupos de países que adotam quotas tarifárias. O primeiro deles se constitui por aquelas nações que compram efetivamente do Brasil, seja intraquota ou extraquota. Nesse rol, encontram-se Estados Unidos e União Européia (os grandes mercados mundiais), Coréia do Sul, Filipinas, Malásia, Tailândia, Polônia, África do Sul, Marrocos, Austrália e Israel. Esse grupo é constituído principalmente por economias desenvolvidas e algumas economias medianas com população expressiva.

De um lado estão Estados Unidos e União Européia, grandes mercados mundiais e também grandes produtores agrícolas. Um processo de liberalização das quotas tarifárias nesses países teria impacto direto nas suas 
políticas de apoio doméstico e subsídios à exportação, uma vez que se perderia uma forma eficaz de conter a oferta de produtos agrícolas nessas economias.

Se quotas tarifárias auxiliam a manutenção da produção e renda de produtores agrícolas nos Estados Unidos e na União Européia, um processo de liberalização desse sistema seria pouco desejável. Daí a menção direta à manutenção e intensificação do sistema de quotas tarifárias nas propostas agrícolas de negociação multilateral da recente Rodada Doha e em acordos regionais, como o UE-Mercosul.

A Austrália é um grande produtor agrícola e impõe apenas uma quota tarifária sobre produtos agroindustriais de interesse ao Brasil. Não há grandes problemas na sua liberalização.

Israel sofre forte influência norte-americana, com a qual possui ligações históricas e acordos preferenciais expressivos. A liberalização das quotas tarifárias nesse país desviaria o comércio antes efetivado com os Estados Unidos, o que pode ser um ponto de pressão para manutenção do sistema.

Países asiáticos são bastante populosos, o que representa um grande mercado consumidor para produtos alimentícios. Nesse sentido, a liberalização das quotas tarifárias promoveria a redução dos preços domésticos de alimentos, sendo, portanto, uma oportunidade às empresas exportadoras brasileiras. Entretanto, há ainda a questão da proteção à produção doméstica de alimentos, o que pode vir a ser um foco de pressão para manutenção do sistema de quotas tarifárias nessas nações.

Os demais países são economias menores. Embora importem produtos agroindustriais brasileiros impondo um sistema de quotas tarifárias, tendem a manter o sistema como forma de proteção a seus produtores 
domésticos, utilizando-se do sistema apenas como forma de suprir a escassez doméstica.

Outro grupo que impõe quotas tarifárias sobre os principais produtos agroindustriais brasileiros é constituído por aquelas nações que não oferecem acesso aos produtos agroindustriais brasileiros em número expressivo de suas quotas tarifárias. Nesse rol estão México, Venezuela, Colômbia, Guatemala e Hungria. Via de regra, percebe-se que são países de economia pequena (quatro latino-americanos e um do Leste Europeu). É provável que sua restrição esteja ligada a sua competitividade internacional, o que exige uma proteção efetiva do setor agrícola nesses países.

Um processo de liberalização das quotas tarifárias nessas nações, dado que possuem um mercado consumidor expressivo, teria impacto positivo na pauta exportadora brasileira. Entretanto, esses países possuem forte atividade agrícola - em alguns casos, são concorrentes diretos do Brasil. Nesse sentido, o objetivo de liberalização não é fácil de ser atingido, além das condições especiais de acesso que muitos deles possuem devido a acordos preferenciais. Ou seja, a competição com o Brasil não é muito desejada.

O terceiro grupo é constituído por aquelas nações que não compram do Brasil. Esses países são representados por Equador, Barbados, Panamá, Eslovênia, República Eslovaca, República Checa, Islândia, Noruega e Tunísia. Em geral, esse grupo é composto por economias muito pequenas. Salvo Islândia e Noruega, que possuem boa qualidade de vida, os demais em certo grau passam por dificuldades econômicas. Equador, Barbados e Panamá são economias fortemente influenciadas pelos Estados Unidos. Os demais têm como seu principal foco de influência a União Européia. Em certo grau são países em que a atividade agrícola é representativa no Produto Interno Bruto e de tamanho relativamente reduzido ao se comparar com a área agricultável brasileira. Ou seja, a competição brasileira é predatória para eles. 
Ressalte-se que Islândia e Noruega são casos à parte dessas afirmações. Ambos impõem, de forma comum, elevadas restrições ao comércio agrícola, porém são também grandes importadores de alimentos.

Cabe destacar ainda que, devido ao pequeno tamanho dessas economias, um processo individualizado de liberalização das quotas tarifárias nesses países efetivamente representaria muito pouco para a pauta exportadora brasileira.

Este capítulo indica que o Brasil consegue colocar seus produtos agroindustriais em mercados sujeitos a quotas tarifárias. A garantia de maior acesso, nesse sentido, está na negociação de liberalização do sistema de quotas tarifárias e sua adequação às condições de demanda doméstica em cada um dos países com o qual estiver negociando. A posição brasileira deve cobrar, portanto, rigor quanto ao cumprimento das prerrogativas do GATT/OMC de não-discriminação e transparência e do compromisso de acesso mínimo e corrente do AARU. Essas medidas, se aplicadas efetivamente, certamente vão garantir maior acesso aos produtos agroindustriais brasileiros, uma vez que não há espaço para a extinção do sistema de quotas tarifárias no foro multilateral. 


\section{CONCLUSÕES}

Este trabalho apontou a interferência do sistema de quotas tarifárias sobre a exportação agroindustrial brasileira. Foram analisadas 352 dentre 1425 quotas tarifárias registradas na OMC até o final do ano de 2001, compreendendo 26 dos 43 países que impõem este sistema às suas importações.

Primeiramente, este trabalho abordou dados agregados, coletados a partir de documentos da Secretaria da OMC. Os números apontados mostraram-se pouco conclusivos por não demonstrarem resultados esperados a partir do referencial teórico adotado.

Utilizou-se, como referencial teórico, a economia internacional e a microeconomia para descrever o funcionamento e as características do sistema de quotas tarifárias.

Sob a ótica teórica, o sistema de quotas tarifárias possui 4 variáveis tangíveis principais, a saber: tarifa intraquota, tarifa extraquota, o tamanho da quota e a demanda por importação (dada a hipótese de elasticidade infinita da curva de oferta mundial). Estas variáveis permitem uma análise cartesiana quanto aos efeitos de qualquer alteração no equilíbrio inicial.

Entretanto, variáveis intangíveis, tais como política comercial, pressões sociais, poder de lobbies, entre outras, incidentes principalmente sobre os sistemas de distribuição de direitos de importação, também estão muito presentes na utilização de quotas tarifárias. Por sua vez, essas variáveis 
distorcem ainda mais o comércio e variam de país a país e produto a produto, o que explica o caráter bastante heterogêneo encontrado nos resultados.

Procuraram-se comportamentos, características e aspectos comuns entre os métodos de administração e os níveis de preenchimento das quotas, entre os métodos de administração e os níveis tarifários adotados e entre o preenchimento das quotas e as tarifas aplicadas. Entretanto, os aspectos comuns encontrados não puderam ser considerados regras. Ou seja, diferentes resultados são encontrados para uma mesma medida de liberalização. Isto reforça a tese de que as quotas tarifárias não obedecem a um comportamento comum frente às medidas de liberalização comercial.

A literatura afirma que uma redução de tarifa de importação ou aumento de quota, no sistema de quotas tarifárias, não determina necessariamente aumento de acesso a mercado. Isso é comprovado no presente trabalho, tanto no aspecto teórico, no qual a efetividade de cada instrumento da quota tarifária (tarifa intraquota, tarifa extraquota e a quota) determina uma medida específica para que ocorra maior acesso a mercado em um movimento de liberalização, quanto no aspecto prático, legal e institucional, onde se encontra um ambiente favorável a manutenção do sistema, este moldado e ratificado a não oferecer lacunas legais para embates jurídicos (embora seja conflitante com os princípios do GATT e OMC) e configurando-se em mais um obstáculo ao comércio, por meio da burocracia imposta e a incidência custos de transação desnecessários.

O Brasil, na prática, não utiliza quotas tarifárias como limitador de comércio. Porém, pôde-se retratar neste trabalho que as exportações brasileiras, daqueles produtos mais importantes na sua pauta do agronegócio, são diretamente afetados por esse sistema. 
Os principais mercados mundiais, tais como os Estados Unidos e a União Européia, utilizam o sistema de quotas tarifárias sobre a sua agricultura. Destaca-se que este sistema tornou-se um grande aliado desses governos, por ser um instrumento que facilita o gerenciamento do comércio, principalmente para aqueles que precisam de controle de demanda interna para a manutenção de seus sistemas de aporte financeiro governamental à produção doméstica.

Segundo a Organização para a Cooperação e Desenvolvimento Econômico (OCDE) ${ }^{25}$, União Européia e Estados Unidos (bem como, Canadá, República Checa, Hungria, Islândia, Coréia do Sul, México, Noruega, Polônia e República Eslovaca) oferecem suporte financeiro à produção de açúcar, milho, oleaginosas, carne bovina, carne suína e carne de aves para seus produtores. Todos esses produtos são, de algum modo, sujeitos a quotas tarifárias nesses países. Assim a imposição de quotas tarifárias passa a possuir a importante tarefa de controlar a oferta doméstica de produtos importados e assim impedir um dispêndio governamental progressivo, o que as tornam importantes para a manutenção de políticas de apoio interno e incentivos às exportações.

O estudo da aplicação do sistema de quotas tarifárias possui ainda inúmeras lacunas que devem ser preenchidas. Há ainda muito a ser percorrido pelo Brasil quanto à discussão das formas protecionista de comércio e os impactos sobre as suas exportações. Nesse sentido, este trabalho é limitado por não apontar os reais impactos de medidas de liberalização do sistema de quotas tarifárias. Entretanto, vários pontos quanto à mensuração das variáveis pertinentes, aspectos teóricos e condições legais e institucionais que estabelecem custos de transação desnecessários, puderam ser levantados.

Sob a ótica econômica, as quotas tarifárias impedem a livre aplicação das vantagens comparativas. Ao não assegurar o princípio da não

${ }^{25}$ Organização para a Cooperação e Desenvolvimento Econômico (OECD) Agricultural policies in OECD countries monitoring and evaluation. (OECD annual publications) 2002. Paris, p.158. 
discriminação, ou seja, ao permitir a distribuição discricionária de licenças de importação, as quotas tarifárias punem produtores mais eficientes, que sem a adoção do sistema, abasteceriam o mercado importador.

Sob a ótica comercial, as quotas tarifárias perpetuam condições discriminatórias resultantes, principalmente, da ação de lobbies de grupos favorecidos, entre os quais, produtores de gêneros agrícolas de países que subsidiam sua agricultura. O que se contrapõe às medidas de liberalização defendidas pelo GATT/OMC, oriundas da adoção da regra NFM.

Sob a ótica das relações internacionais, o sistema de quotas tarifárias, bem como as demais medidas protecionistas de comércio, favorecem diretamente os conflitos e disputas comerciais.

Outro ponto a ser destacado são os complicados métodos de administração das quotas tarifárias que se confrontam diretamente com o princípio da transparência, defendidos no foro multilateral de comércio. Ainda quanto ao princípio da transparência, vários problemas foram encontrados quanto a disponibilidade de informações oficiais. Verificou-se a existência constante de informações oficiais incompletas e desatualizadas, bem como quadros tarifários que não representam as tarifas realmente aplicadas, além de metodologias de cálculo não publicadas, como é o caso da mensuração do consumo doméstico, importante para especificar o volume de acesso mínimo.

A pouca transparência das quotas tarifárias, difundida na literatura e comprovada no presente trabalho, impede que seja verificado satisfatoriamente o cumprimento de outros pontos dos acordos comerciais, entre os quais, a condição de acesso mínimo.

Além do princípio da transparência, a adoção do sistema de quotas tarifárias (desde sua retomada na Rodada Uruguai) também conflita com outros princípios e artigos de acordos de comércio. 
Por estabelecer uma forma de distribuição de direitos de importação, o sistema de quotas tarifárias fere o artigo I do GATT que dispõe sobre a regra NMF e seu princípio mais fundamental, o de não discriminação.

O artigo XI do GATT proíbe a utilização de restrições quantitativas. Entretanto, quando as quotas tarifárias assumem o regime quota, estas comportam-se como um sistema de quotas puro. O que é, por natureza, uma restrição quantitativa.

O artigo XIII do GATT preconiza que a administração de restrições quantitativas deve seguir um critério não discriminatório. Verifica-se, entretanto, que muitos dos métodos aceitos pela OMC, são discricionários ou utilizam tratamento especial para a distribuição de quotas, devido a acordos preferenciais e regionais. Complementando esta idéia, o Acordo sobre Processos de Licenciamento das Importações da OMC propõe que a distribuição de direitos de importação ocorra de forma neutra e justa, seu comitê sobre licenciamento deveria procurar, portanto, melhorar a transparência dos métodos de administração das quotas tarifarias, por meio do estrito cumprimento do disposto nos artigos XIII e XI do GATT.

As questões levantadas sobre a relação entre os acordos de comércio internacional e a adoção do sistema de quotas tarifárias ao final da Rodada Uruguai, salienta uma afirmação: as quotas tarifárias foram retomadas e ratificadas, inclusive pelo Brasil, em meio a contradições entre os princípios que regem o comércio multilateral e a prática protecionista comercial. Certamente, o estrito cumprimento das regras multilaterais de comércio, defendidas pelo GATT/OMC, ofereceriam maior acesso aos mercados internacionais para países mais eficientes na produção de gêneros agroindustriais.

Porém, percebe-se o assentamento do sistema de quotas tarifárias nos meandros dos acordos. O que o torna inquestionável do ponto de vista das 
relações internacionais. Assim, a expansão do acesso aos mercados, sujeitos as quotas tarifárias, está fadada à intensa negociação de comércio internacional, principalmente no foro multilateral.

Há duas opções quanto à estratégia para a negociação das quotas tarifárias: a defesa de sua extinção ou a manutenção do sistema e discussão de maneiras para melhorá-lo.

A primeira opção pode auferir dois resultados: uma real liberalização do comércio agrícola internacional ou a intensificação do uso de outras formas de restrição ao comércio (simples substituição de instrumentos de proteção).

Nesse sentido, considerando que o sistema é imposto sobre aqueles produtos mais sensíveis, ou seja, justamente aqueles produtos que necessitam maior proteção ao comércio, a opção de real liberalização do comércio agrícola torna-se pouco factível nas negociações internacionais. Por outro lado, a intensificação do uso de outras medidas de proteção não traria grandes impactos sobre o acesso a mercados, além de representar o enfraquecimento do foro multilateral para questões comerciais, o que não é uma boa estratégia para o Brasil.

Vale ressaltar que mesmo em países eficientes e competitivos há a adoção de quotas tarifárias em alguns setores específicos (aqueles em que são mais sensíveis), logo, nem mesmo esses países são completamente a favor da extinção do sistema de quotas tarifárias. Isto é comprovado em recentes propostas de negociação sobre agricultura na Rodada Doha. Estas propostas não mencionam qualquer pretensão a extinção do sistema de quotas tarifárias. Ao contrário, especificam as quotas tarifárias em suas modalidades e sinalizam para sua expansão.

Dado que a opção de extinção do sistema de quotas tarifárias é pouco provável, os negociadores brasileiros devem se preparar para enfrentar a 
segunda opção, ou seja, negociar as quotas tarifárias, buscando melhorar as condições de acesso de produtos agroindustriais brasileiros nos mercados internacionais.

A opção de negociar quotas tarifárias aponta, também, para duas possibilidades: a expressiva redução de tarifas que, dada a competitividade brasileira, proporcionaria exportação extraquota ou a identificação do regime assumido por cada quota tarifária, juntamente com a negociação do instrumento efetivo em cada caso.

Sob esse enfoque, o presente trabalho verificou a existência de picos tarifários para as tarifas extraquota, na quase totalidade de quotas tarifárias estudadas. Assim, para que houvesse exportação brasileira extraquota, a redução dessas tarifas deveria ser muito intensa. O que também não é factível. Uma vez que as quotas tarifárias, em geral, são direcionadas a produtos sensíveis com forte ação política doméstica e a grandes beneficiários de apoio interno e incentivos às exportações. Ou seja, produtos que exigem dos seus governos, crescente proteção à concorrência internacional.

Identificar os regimes assumidos por cada quota tarifária e negociar o seu instrumento efetivo é a estratégia mais viável para uma negociação frutífera em acesso a mercado. Entretanto, a negociação de acesso a mercado na agricultura possui um universo de cerca de 1800 linhas tarifárias nos Estados Unidos e cerca de 2200 linhas tarifárias na União Européia. O estudo indicado teria de considerar 1425 quotas tarifárias (ou pelo menos 92 para os produtos de maior interesse do Brasil).

Um estudo, como este, deveria apontar a real distribuição das licenças de importação e os entraves políticos e institucionais que provocam custos de transação adicionais. Identificar o equivalente ad valorem adotado em cada quota tarifária, ponderando-os de alguma forma e assim evitar problemas relacionados a "dirty tariffication". Deve-se seguir a mensuração do consumo 
doméstico, por meio da metodologia adotada ao final da Rodada Uruguai em cada país, e assim encontrar o valor do volume para acesso mínimo. Cabe destacar que no volume de acesso mínimo podem estar incluídos outros produtos que não aqueles sujeitos a quotas tarifárias.

Uma verificação das importações de cada linhas tarifária deve ser realizada, a fim de encontrar as linhas tarifárias que tem menor participação quanto ao preenchimento das quotas, bem como verificar as origens das importações comparando-as com os possíveis acordos preferenciais ou regionais oferecidos pelo país estudado. Certamente serão encontrados casos relacionados a "dirty quotification". O que é uma informação crucial nos processo de negociação das quotas tarifárias.

Ainda, seria necessária a mensuração de uma curva de demanda por importação e a estimação dos parâmetros necessários a sua realização. Então por meio de metodologias específicas, as quais destacam-se modelos de equilíbrio parcial como o demonstrado em artigo de Abbott e Paarlberg (1999) e modelos de equilíbrio geral computáveis como o apresentado em artigo de Tsigas e Ingco (2001). Assim, seria formado um quadro completo de uma quota tarifária e conseguiria-se identificar quantitativamente os reais impactos de medidas de liberalização dentro de um sistema de quotas tarifárias.

Medir os reais impactos de medidas de liberalização das quotas tarifárias configura-se uma tarefa muito dispendiosa e individualizada quota a quota. Uma vez que a negociação global sobre sistema de quotas tarifárias deve considerar questões gerais e que o presente trabalho verificou que a análise agregada das quotas tarifárias não traz informações conclusivas quanto ao comportamento do sistema frente medidas de liberalização, propõe-se aos negociadores: 
a. a busca por transparência quanto a imposição de quotas tarifárias, por meio registros sistemáticos e agregação de informação pertinente na OMC;

b. o cumprimento rigoroso das condições de acesso mínimo e corrente do AARU e facilitação, por meio de metodologia comum, do cálculo do consumo doméstico;

c. a desvinculação da distribuição de direitos de importação de acordos preferenciais ou destinados a países específicos, ou seja, cumprimento estrito dos artigos XI e XIII do GATT;

d. métodos de adminstração simples, voltados a concorrência, entre os quais, preferencialmente, o leilão, o first come, first served e as licenças sobre demanda;

e. a permissão para a transação de direitos de importação, assim, constituindo um mercado oficial mundial para as quotas;

f. estabelecer um canal multilateral para a informação corrente sobre os sistema de quotas tarifárias, como abertura de temporada de importação intraquota, volumes de licenças solicitadas, leilões, entre outras informações, reduzindo-se assim o custo de transação envolvidos nas exportações sujeitas a quotas tarifárias;

g. cortes tarifários significativos, tanto intraquota, quanto extraquota;

h. a expansão do volume das quotas, obedecendo o disposto pelo compromisso de acesso mínimo;

i. orientação para que cada quota tarifária considere apenas uma única linha tarifária, evitando-se assim o processo de "dirty quotification"; 
Cabe destacar que as quotas tarifárias geralmente vêm acompanhadas de outras formas de restrição tarifária e não tarifária tais como salvaguardas especiais, escaladas tarifárias, medidas sanitárias e fitossanitárias, medidas de ordem técnica, entre outras. Assim as medidas de transparência e não discriminação propostas devem também ser estendidas a qualquer forma de restrição comercial, condição preconizada desde a criação do GATT em 1947.

O presente trabalho defende o livre mercado no comércio internacional de produtos agrícolas, esta opção deve-se ao fato de que a manutenção do sistema de quotas tarifárias representa menor acesso aos mercados, portanto, impacto negativo direto sobre a balança comercial do Brasil. Entretanto, cabe ressaltar que do ponto de vista social, a manutenção do sistema de quotas tarifárias é crucial para a ajuda às economias menores, por meio de acesso preferencial e distribuição de quotas a países específicos.

Em síntese, ao descrever o funcionamento e características do sistema de quotas tarifárias, discutir sua inserção no GATT e na OMC e levantar os produtos agroindustriais brasileiros mais afetados por esse sistema pode-se afirmar que garantir maior acesso a mercado é muito mais complicado do que se espera. Sua construção teórica é relativamente simples, entretanto, seu assentamento jurídico e institucional esconde lacunas importantes que influenciam o jogo comercial.

Como diria Sir Willian Shakespeare em Hamlet: "Há muito mais entre o céu e a terra do que sonha a nossa vã filosofia". Ou seja, este trabalho cobriu uma parte ínfima no que tange o tema quotas tarifárias. Apenas mostrou a "ponta de um iceberg". Uma vez que não foram encontrados outros trabalhos sobre o tema em língua portuguesa, há muito ainda por ser realizado, não só enfatizando as quotas tarifárias, mas também as demais restrições à inserção comercial brasileira nos mercados internacionais. O Brasil passa por um 
período inédito em sua história comercial ao negociar dois acordos regionais de grande envergadura e assumir papel de destaque nas negociações agrícolas. Nesse intuito, é fundamental evitar erros - como a ratificação do sistema de quotas tarifárias ao final da Rodada Uruguai - que se estude as medidas de restrição comercial.

\subsection{Considerações sobre futuros trabalhos}

O presente trabalho cobriu uma parte ínfima do que corresponde o universo das quotas tarifárias. Ficam ainda, inúmeras questões não respondidas, que são de extrema importância aos negociadores brasileiros e aos produtores nacionais no que tange o acesso de seus produtos no mercado internacional.

Assim, propõe-se:

a. estudo setorial sobre as exportações sujeitas a quotas tarifárias;

b. estudo específico, quota a quota, identificando-se os regimes, estimando as curvas de demanda e verificando o real impacto das medidas de liberalização do sistema de quotas tarifárias sobre as exportações brasileiras. Para tanto são oferecidas duas metodologias, apontadas neste trabalho: modelos de equilíbrio parcial (Abbott e Paarlberg, 1999) e modelos de equilíbrio geral computáveis (Tsigas e Ingco, 2001).

c. discussão relacionada às questões jurídicas dos acordos de comércio e a imposição de quotas tarifárias, enfatizando as relações internacionais, poder dos lobbies, etc;

d. estudo da correlação entre a adoção de quotas tarifárias, apoio interno à produção e incentivos às exportações; 
e. descrição sobre a forma de aplicação dos métodos de administração em diferentes países;

f. mensuração de custos de transação que derivam da adoção do sistemas de quotas tarifárias. 
ANEXO 
ANEXO - Descrição oficial: nomenclatura dos capítulos do sistema harmonizado da OMC.

Este anexo traz as descrições oficiais de cada capítulo, conforme disposto no sistema harmonizado da OMC, como segue:

Capítulo I. Animais Vivos;

Capítulo II. Carnes e miudezas, comestíveis;

Capítulo III. Peixes e crustáceos, moluscos e os outros invertebrados aquáticos;

Capítulo IV. Leite e laticínios; ovos de aves; mel natural; produtos comestíveis de origem animal, não especificados nem compreendidos em outros Capítulos;

Capítulo V. Outros produtos de origem animal, não especificados nem compreendidos em outros Capítulos;

Capítulo VI. Plantas vivas e produtos de floricultura;

Capítulo VII. Produtos hortícolas, plantas, raízes e tubérculos, comestíveis;

Capítulo VIII. Frutas; cascas de cítricos e de melões;

Capítulo IX. Café, chá, mate e especiarias;

Capítulo X. Cereais;

Capítulo XI. Produtos da indústria de moagem; malte; amidos e féculas; inulina; glúten de trigo;

Capítulo XII. Sementes e frutos oleaginosos; grãos, sementes e frutos diversos; plantas industriais ou medicinais; palha e forragem;

Capítulo XIII. Gomas, resinas e outros sucos e extratos vegetais; 
Capítulo XIV. Matérias para entrançar e outros produtos de origem vegetal, não especificados nem compreendidos em outros Capítulos;

Capítulo XV. Gorduras e óleos animais ou vegetais; produtos da sua dissociação; gorduras alimentares elaboradas; ceras de origem animal ou vegetal;

Capítulo XVI. Preparações de carne, de peixes ou de crustáceos, de moluscos ou de outros invertebrados aquáticos;

Capítulo XVII. Açúcares e produtos de confeitaria;

Capítulo XVIII. Cacau e suas preparações;

Capítulo XIX. Preparações à base de cereais, farinhas, amidos, féculas ou de leite; produtos de pastelaria;

Capítulo XX. Preparações de produtos hortícolas, de frutas ou de outras partes de plantas;

Capítulo XXI. Preparações alimentícias diversas;

Capítulo XXII. Bebidas, líquidos alcoólicos e vinagres;

Capítulo XXIII. Resíduos e desperdícios das indústrias alimentares; alimentos preparados para animais;

Capítulo XXIV. Fumo (tabaco) e seus sucedâneos, manufaturados;

Capítulo XXIX. Produtos químicos orgânicos;

Capítulo XXXIII. Óleos essenciais e resinóides; produtos de perfumaria ou de toucador preparados e preparações cosméticas;

Capítulo XXXV. Matérias albuminóides; produtos à base de amidos ou de féculas modificados; colas; enzimas;

Capítulo XXXVIII. Produtos diversos das indústrias químicas;

Capítulo XLI. Peles, exceto a peleteria (peles com pêlo*), e couros; 
Capítulo XLIII. Peleteria (peles com pêlo*) e suas obras; peleteria (peles com pêlo*) artificial;

Capítulo L. Seda;

Capítulo LI. Lã e pêlos finos ou grosseiros; fios e tecidos de crina ;

Capítulo LII. Algodão. 


\section{REFERÊNCIAS BIBLIOGRÁFICAS}

ABBOTT, P.C. Tariff rate quotas: failed market access instruments? EUROPEAN ASSOCIATION OF AGRICULTURAL ECONOMISTS SEMINAR, 77. Helsinki, 2001. International agricultural trade: old and new challenges. 25p.

ABBOTT, P.C.; PAARLBERG, P.L. Tariff rate quotas: structural and stability impacts in growing markets. Agricultural Economics, v.19, p.257-267, 1998.

ACCIOLY, H.; SILVA, G.E.N. Manual de direito internacional público. 12.ed. São Paulo: Saraiva, 1996. p.467.

BAGWELL, K.; STAIGER, R.W. Reciprocity, non-discrimination and preferential agreements in the multilateral trading system. European Journal of Political Economy, v.17, p.281-325, 2001.

BERGSTEIN, C.F. Globalising free trade. Foreign Affairs, v.75, p.105-120, May/June, 1996.

BRASIL. Ministério do Desenvolvimento, Industria e Comercio Exterior (MDIC). Secretaria de Comércio Exterior (SECEX). AliceWeb. http://aliceweb.desenvolvimento.gov.br/ (21 set. 2003)

BUREAU, J.; TANGERMANN, S. Tariff rate quotas in the European Union. Agricultural and Resource Economic Review, v.29, n.1, p-70-80, 1999.

BUSSAB, W.O.; MORETTIN, P.A. Estatística básica. 4.ed. São Paulo: Atual Editora, 1987. 321p. 
DEGORTER, H.; SHELDON, I. Agriculture in the WTO: issues in reforming tariff-rate quotas in the agreement on agriculture in the WTO. St. Paul: University of Minessota, Department of Applied Economics, International Agricultural Trade Research Consortium (IATRC), 2001. 180p. (Commissioned Paper, 13)

DESTA, M.G. The law of international trade in agricultural products: from GATT 1947 to the WTO agreement on agriculture. The Hague: MPG Books, Kluwer Law International The Hague, 2002. 468p.

GERVAIS, J.; SURPRENANT, D. An economic investigation of the import licensing methods and TRQs in agriculture. Sta-Foy QC: Université Laval, Department of Agricultural Economics and Consumer Studies, 2000. 21p. GIBSON, P.; WAINIO, J.; WHITLEY, D.; BOHMAN, M. Profiles of tariffs in global agricultural markets. Washington: U.S. Department of Agriculture, Economic Research Service, Market and Trade Economics Division, 2001. 44p. (Agricultural Economic Report, 796)

HERRMANN, R.; KRAMB, M.; MÖNNICH, C. Tariff rate quotas and the economic impacts of agricultural trade liberalization in the WTO. International Advances in Economic Research, v.7 n.1, p.1-19, 2001.

HOEKMAN, B.; MATTOO, A.; ENGLISH, P. Development, trade and WTO: a handbook. Washington: The International Bank for Reconstruction and Development / The World Bank, 2002. 641p.

HOEKMAN, B.M. Trade laws and institutions: good practices and the World Trade Organization, 1995. 106p. (World Bank Discussion Papers, 282) HOEKMAN, B.M.; KOSTECKI, M.M. The political economy of the world trading system. 2.ed. Oxford: Oxford University Press, 2001. 547p.

HOFFMANN, R. Estatística para economistas. 2.ed. São Paulo: Livraria Pioneira Editora, 1991. 426p. 
HORN, H.; MAVROIDIS, P.C. Economic and legal aspects of the most-favorednation clause. European Journal of Political Economy, v.17, p.233-279, 2001.

JACKSON, J. The world trading system: law and policy of international relations. Cambridge: MIT Press, 1999. 441p.

JACKSON, J.H.; DAVEY, W.J.; SYKES, A.O. Jr. Legal problems of international economic relations: cases, materials and text. 3.ed. St. Paul: West Group, 1995. 1248p.

JOERIN, R.; LENGWILER, Y. Learning from financial markets: auctioning tariffrate quotas in agricultural trade. Swiss Journal of Economics and Statistics /forthcoming/ http://www.unibas.ch/wwz/witheo/yvan/ research.htm (17 Dec. 2003)

LLOYD, P.J. The architecture of the WTO. European Journal of Political Economy, v.17, n.2, p.327-353, 2001.

MACIENTE, A.N. A formação da ALCA e de um acordo de livre comércio entre o Mercosul e a União Européia: uma análise comparada. São Paulo, 2000. 80p. Dissertação (M.S.) - Faculdade de Economia, Administração e Contabilidade, Universidade de São Paulo.

MAS-COLELL, A.; WHINSTON, M.D.; GREEN, J.R. Microeconomic theory. New York: Oxford University Press, 1995. 1008p.

MATTHEWS, A.; LAROCHE-DUPRAZ, C. Agricultural tariff rate quotas as a development instrument. Dublin: Department of Economics of Trinity College Dublin, 2002. 21p.

MORATH, T. TRQs have little impact on EU market access, while CEEs may benefit. Washington: Market and Trade Economics Division, Economic Research Service, U.S. Department of Agriculture. Washington, 1997. 12p. (WRS 97-5) 
PAARLBERG, P.L.; LEE, J.G. U.S. trade policy on lamb meat: who gets fleeced? American Journal of Agricultural Economics, v.83, n.1, p.196208, 2001.

SCHWARTZ, W.F.; SYKES, A.O. Toward a positive theory of the most favored nation obligation and its exceptions in the WTO/GATT system. International Review of Law and Economics, v.16, p.27-51, 1996.

SILBERBERG, E. The structure of economics: a mathematical analysis. 2.ed. New York: McGraw-Hill Pub., 1990. 688p.

SKULLY, D.W. Economics of tariff-rate quota administration. Washington: U.S. Department of Agriculture, Economic Research Service, Market and Trade Division, 2001a. 23p. (Technical Bulletin,1893)

SKULLY, D.W. Five years of tariff-rate quotas: a status report. Washington: U.S. Department of Agriculture, Economic Research Service, Nov. 2000. p.22-25. (Agriculture Outlook, 276)

SKULLY, D.W. Liberalizing tariff-rate quotas. Agricultural Policy Reform: the road ahead. Washington: U.S. Department of Agriculture, Economic Research Service, Market and Trade Economics Division, 2001b. p.59-67. (Agricultural Economic Report, 802)

TANGERMANN, S. Has the Uruguay round agreement on agriculture worked well? Saint Paul: International Agricultural Trade Research Consortium (IATRC), 2001. 36p. (Working Paper, 01-1)

TSIGAS, M.E.; INGCO, M. Market access liberalization for food and agricultural products a general equilibrium assessment of tariff-rate quotas. Washington: Office of Economics, U.S. International Trade Commission, 2001. 18p. (Working Paper, 2001-10-A) 
UNITED STATES DEPARTMENT OF AGRICULTURE (USDA). Economic Research Service. WTO Ag Trade Policy Commitments: WTO tariff levels. http://www.ers.usda.gov/db/Wto/WtoTariff_database/Default.asp?ERSTab=3 (05 July 2003)

WORLD TRADE ORGANIZATION (WTO). The legal texts: the results of the Uruguay round of multilateral trade negotiations. New York: Cambridge University Press, 2001. p.492.

WORLD TRADE ORGANIZATION (WTO). Welcome to documents on line: advanced search: TN/AG/S/5. http://docsonline.wto.org/ gen_home.asp?language $=1 \&$ _ $=1$ (18 sep. 2002)

WORLD TRADE ORGANIZATION (WTO). The General Agreement on Tariff and Trade (GATT 1947): documents: legal texts. http://www.wto.org/english/ docs_e/legal_e/gatt47_01_e.htm Genebra (20 Mar. 2003) 